\title{
The Internalization of the European Administrative Space principles in national public administrations. Study Case: Romania
}

Prof.Dr. Ani Matei, Prof.Dr. Lucica Matei, Dr. Diana - Camelia lancu

Research Report written within the framework of Jean Monnet project "South-

Eastern European developments on the administrative convergence and enlargement of the European Administrative Space in Balkan states" 


\section{Table of Contents}

1. EUROPEAN UNION AND THE EUROPEANIZATION PROCESS. AN OVERVIEW ................. 4

1.1. THE LITERATURE ON EUROPEANIZATION: A POSSIBLE THEORETICAL FRAMEWORK ................... 4

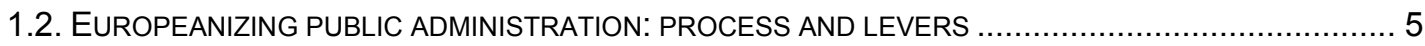

1.3. THE CONCEPT OF INTERNALIZING NORMS. ON DOMESTIC SALIENCE $\ldots \ldots \ldots \ldots \ldots \ldots \ldots \ldots \ldots \ldots \ldots . \ldots$

2. THE EUROPEAN ADMINISTRATIVE SPACE IN THE CONTEXT OF EUROPEANIZATION 11

2.1. GenERAL CONCEPT OF THE EUROPEAN AdMINISTRATIVE SPACE.................................... 11

2.2. A POSSIBLE OPERATIONALIZATION OF THE EUROPEAN AdMINISTRATIVE SPACE..................... 12

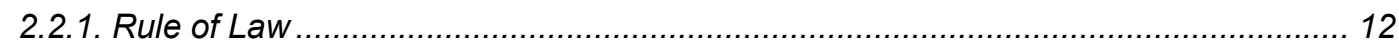

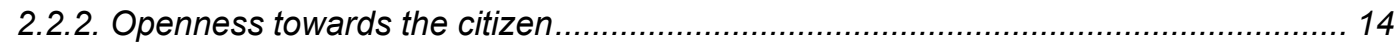

2.2.3. Self-responsibility of the public administration.............................................. 15

3. THE INTERNALIZATION OF THE EUROPEAN ADMINISTRATIVE SPACE IN ROMANIA.. 17

3.1. AN OVERVIEW OF THE PUBLIC ADMINISTRATION IN ROMANIA ..................................... 17

3.2. EUROPEANIZING PUBLIC ADMINISTRATION IN ROMANIA ........................................... 18

3.2.1. Acquis communautaire as Europeanization lever.............................................. 19

3.2.2. Pre-accession funds as Europeanization lever............................................... 20

3.2.3. Institutional twining as Europeanization lever................................................ 21

3.2.4. Public Administration under Reform. Inputs on the rule of law, openness and self-

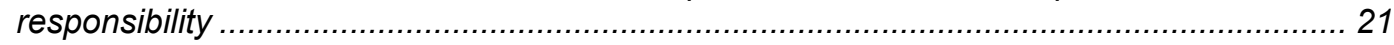

4. THE EUROPEAN ADMINISTRATIVE SPACE IN ROMANIA. EMPIRICAL EVIDENCES ON ITS INTERNALIZATION ................................................................................................ 25

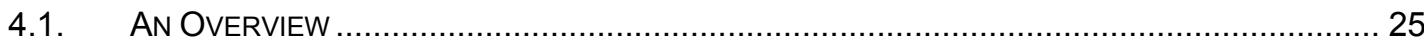

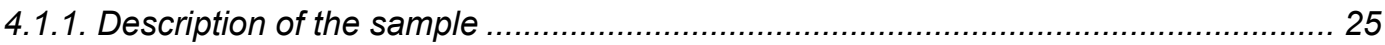

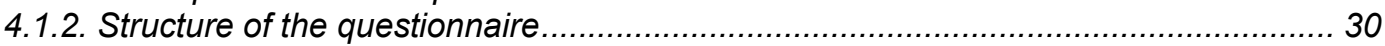

4.2. DETERMINING THE EMPIRICAL CHARACTERISTICS OF THE INTERNATIONALIZATION OF THE

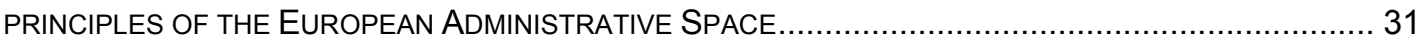

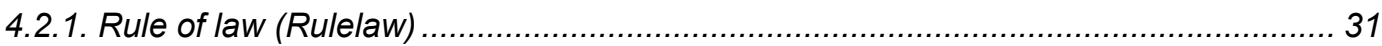

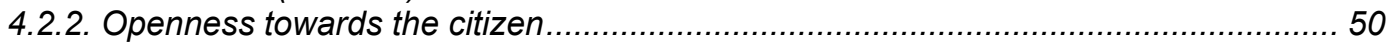

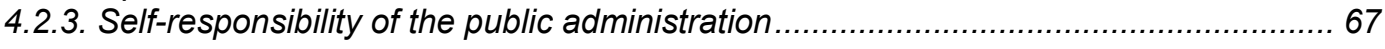

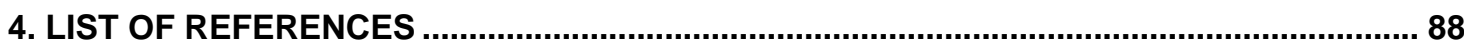

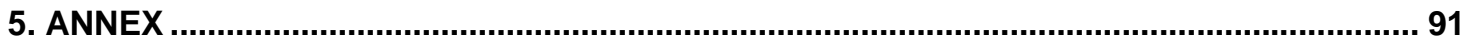




\begin{abstract}
Among different sociological concepts and theories applicable to the study of the process of Europeanization of public administration, internalization is but seldom to be encountered. The internalization of the principles of the European Administrative Space (EAS) in the national public administrations appears as both a learning process, as well as a process of organizational change, a consequence of the interaction between individual learning, civil servants and public employees, and organizational learning, at the level of public institutions and authorities.
\end{abstract}

The mechanisms that favor internalization are multiple, and are extracted from the complexity of the activities implied by the European integration; without it, one could not differentiate between the amounts of information available. The authors of the present report chose to make an assessment based on empirical researches, and an interpretation in accordance to the statistical instruments employed.

This report is structured in three chapters regarding the European Union and the process of Europeanization, EAS in the context of Europeanization, as well as the internalization of the EAS principles in Romania. The empirical and statistical approach represents the largest part of the report, offering significant details for which those interested may constitute the premises for further developments.

Actually, the formulated conclusions may be even more deepened and associated with action plans to determine a further internalization of the EAS principles.

Keywords: European Administrative Space, internalization, Europeanization, socio-statistical analysis 


\section{European Union and the Europeanization Process. An Overview}

\subsection{The literature on Europeanization: A possible theoretical framework}

Putting aside the pure intentional objectives of political and ideological nature, the European Union can be seen as the most visible international actor in the institutional Europe of today. Since January 2007, 27 Member States have agreed on participating and contributing to common regional, social, agricultural and monetary markets, creating in between a single European space of security and defense. Conceding an amount of their sovereignty to the European Union, Member States have also agreed on accepting the European acts as a special category of external demands to which answering is usually imperative and driven by common formulated models, standards or institutional arrangements (Andersen, 2004, 17-18). Possible packages of alternative solutions, the latter seem to replace the decrepit internal institutional arrangements, with minimum effort and political debate (Andersen, 2004, 21).

Commonly used, Europeanisation generally implies a product "of the European Union" or "generated by the European Union" ${ }^{1}$. Generically understood it refers to the European Union's impact on the Member States' national orders, is perceived as endogenous to the EU's borders and consensus generator. Still, Europeanization may be exported (Bulmer and Radaelli, 2004, 2). Its products are concentrated in merely 80.000 of acquis communautaire, position papers and country reports, guidelines for application, eligibility criteria and twinning manuals (Matei and lancu, 2007).

\footnotetext{
${ }^{1}$ For relevant discussions on the topics above, please see inter alia, Ladrech (1994); Knill and Lehmkuhl (1999); Bomberg and Peterson (2000); Börzel and Risse (2000); Laegreid (2000); Radaelli (2000); Olsen (2002); Featherstone (2003).
} 
The specter of possible significances of Europeanization is impressive: it can be analyzed as a transnational process (diffusion of Western norms, styles and behaviors within the Western Europe); an institutional process of adaptation to the European Union's demands; a counterbalance to globalization or finally, as a specific strategy for managing the worldwide conflicts (Featherstone, 2003). From all these, the "Europeanization as institutional adaptation" approach has caught the attention of the doctrine of administrative studies and became useful to this Report. In fact here, giving that Romania has been recently accepted to the European Union (January 2007), Europeanization will be hereinafter referred to as a twofold process: possible before the actual accession (Europeanization for Candidate countries) and after the accession to the European Union (Europeanization for Member States).

\subsection{Europeanizing public administration: process and levers}

For Member States and their public administrations, Europeanization generates a distinct governing system, a new set of European structures and public processes which interact with national orders. For Demmke (2004), the levers of European impact are: the European legislation, the negotiation processes, the decision and implementation of, for instance, civil service, administrative cooperation, the European Court of Justice's jurisprudence and the administrative networks newly created in the European space. In regard to the former and current European enlargement and the Europeanization for the Candidate countries, the following paragraphs may be seen as relevant.

In 1993, the Copenhagen European Council established the accession conditions that the Central and Eastern Europe candidates required in order to become Members of the Union (point 7.A.iii):

1. Stability of institutions guaranteeing democracy, the rule of law, human rights and respect for and protection of minorities;

2. Existence of a functioning market economy as well as the capacity to cope 
with competitive pressure and market forces within the Union; and

3. Ability to take on the obligations of membership including adherence to the aims of political, economic and monetary union.

In the same year, the European Interim Agreement entered into force. This document was signed by the European Community and the Candidate countries, and argued, in its Article 98 that: „Parties will promote the cooperation between their administrative authorities, including by exchange programs, in order to improve the level of common knowledge of their systems' structure and functioning".

This new approach was actually to be confirmed a year later, by the White Paper: Preparation of the Associated Countries of Central and Eastern Europe for Integration into the Internal Market of the Union. Without being part of the accession process in the $5^{\text {th }}$ enlargement (relevant to the case of Romania), that document enumerated under the "Specialized Technical Assistance" chapter, point 5.6, some levers that made Europeanization possible:

1. assistance with appraising the costs and benefits of different sequences of approximation;

2. direct and rapid access to complete and up-to-date EU legislative texts and jurisprudence, as well as translation services;

3. advice from legal and technical experts, on the Union's legal system and, sector by sector, about the interpretation of Community texts and the drafting of national laws;

4. information concerning implementation and enforcement mechanisms in the Member States;

5. institutional exchange programmes and TAIEX Programme;

6. access to PHARE, Erasmus, Socrates and Leonardo da Vinci financial assistance.

Two years later, in 1997, the Luxembourg European Council launched the 
enlargement procedure - a "comprehensive, inclusive and ongoing process, which will take place in stages" and organizes the enhance pre-accession strategy, through which the Europe Agreements remain "the basis of the Union's relations" with the applicant states, while the Partnerships become "will mobilize all forms of assistance to the applicant countries of Central and Eastern Europe within a single framework" (points 14 and 16 of the Conclusions of the Luxembourg Council). It is again now that in support of the acquis' adaptation process, the financial assistance and screening are enforced ("the enhance strategy for pre-accession will be accompanied by the analytical study of the European acquis for each Candidate country").

To summarize, a non-exhaustive list of the the levers of Europeanization in case of Candidate countries of the $5^{\text {th }}$ enlargement, as they appear in the Strategic European documents of the European Council, were ${ }^{2}$ :

1. Acquis communautaire, naming the common rights and obligations applied to all EU Member States, comprising the legal norms that regulate the activity of European institutions, actions and policies, namely: declarations and resolutions that were adopted inside the European Union; common actions and positions, signed conventions, resolutions, declarations and other acts adopted within the External and Common Security Policy (ECSP) and the cooperation in the field of Justice and Home Affairs; international agreements to which the European Community is a member, as well as those signed by Member States in connection to the latter.

\section{Pre-accession funds: PHARE, ISPA and SAPARD}

2.1. PHARE - relied primarily on the institutional consolidation and assistance support in the investment area $^{3}$. It provided structural assistance at regional level (institutional construction for economic and social cohesion) and

\footnotetext{
${ }^{2}$ This part of the Report draws from Matei and lancu (2007).

3 In developing the infrastructure needed in order to assure the conformity with the European legislation or the economic and social cohesion
} 
finances measures taken in the fields of cross border cooperation and nuclear security;

2.1. ISPA - organized under the rule of Council Regulation (CE) no.1267/1999 of 21 June 1999; it financed: rehabilitation of the environmental infrastructure (modernizing the water supply resource, sewerage, treatment of used waters, management of urban refuse) and enhances and modernizes the transport infrastructure (modernizing of national roads, rehabilitation and modernization of railways, etc.); and,

2.1. SAPARD, organized under the Council Regulation (CE) no.1268/99 of 21 June 1999); it finances the structural reform of agricultural and rural development sectors, as well as the implementation of the Common Agricultural Policy and its subsequent legislation.

3. Institutional twinning - One of the main challenges the Candidate countries of the last enlargement had to deal with was the administrative capacity criterion established in Madrid. In this sense, the European Union launched in 1998 a human resources and financial mobilization of twinning of administrations and agencies. Concentrated at the beginning on the top one priority sectors (agriculture, environment, public finance, justice and home affairs and preparatory measures for introducing the structural funds), the twinning projects are now covering all the areas of the acquis.

If to assume that national actors are strategic multipliers of utilities, interested only in maximizing their power and welfare, and that they exchange information, threats and promises during the accession negotiation process, while the final outcome depends upon the relative strength of negotiation each possesses, then, it may be concluded that the formal models of the Union were absorbed at domestic level, only if the expected rewards exceeded the internal costs of the model's absorption.

Thus, the cost-benefit balance would have depended on: a) the importance of the norm to be absorbed - was it seen by the European Union as a pre-condition for 
rewarding? (e.g. granting the membership?); b) The clarity of the norm to be absorbed; c) Reward (dimension, time upon receiving, period of "use", etc.); d) European Union's credibility; e) Internal costs of norms' absorption; and, f) The degree of opportunity of the norm's absorption.

According to Sedelmeier (2006, 147 et seq.) and relevant from the point of view of the Europeanization levers already identified, the mechanism the former Candidate countries employed in absorbing the European norms was that of external stimulation by presenting the advantages of European Union's membership; the social learning process or that modeled by previous learning seem not that important. In support of this statement, next to the country reports and the conclusions of annual monitoring, comes the list of benefits EU links to the membership status. The latter was present in almost any political discourse of the Eastern European countries: a stabile political and economic climate that will ensure a durable development; a higher predictability and stability of the economic environment; increase of the access on European capital and investment markets, new equipment and high tech; presence of domestic economic agents on a single, large market; strengthening the national security in order to integrate to ECSP; the European citizenship; perspectives for professional training and access to the European labor market for national citizens.

\subsection{The concept of internalizing norms. On domestic salience}

Scholars of social sciences have tried to demonstrate that international rules influence state behavior by pointing to correlations between the existence of rules and apparent rule-guided state actions (Cortell and Davis, 1996). In fact, part of the relevant doctrine, identified two processes or pathways by which an international institution's rules or norms can become institutionalized at the domestic level. First, it was by infusing the beliefs and values of actors within the state; as pointed by R. McElroy (1992, in Cortell and Davis, 1996, 453): "[T]he 
conscience of a state decision maker can lead him to actually decide in favor of a particular policy action at least in part because of its moral significance." Second, it has been argued that a regime's tenets may become enmeshed in a country's domestic political processes through the standard operating procedures of bureaucratic agencies. Cortell and Davis (1996, 453-454) suggest however two complementary pathways little discussed by the literature. First, government officials and societal actors can invoke an international rule to further their own particularistic interests in domestic policy debates; in other words, a domestic actor can use the existence of an international rule to justify his/her own actions or to call into question the legitimacy of another's. A second way by which an international institution's rules can become institutionalized into the domestic political process is through their incorporation or embodiment in national laws.

However, these pathways, as described by Cortell and Davis $(1996,454)$ will not lead international rules and norms to affect a state's policies in every instance. In fact, there is likely to be some variation in the domestic impact of international rules across countries and across different issue areas within single countries. This variation reflects two factors: the domestic salience of the international rule or norm; and the domestic structure that prevails during a given policy debate.

Relevant to the scope of this Report is the concept of domestic salience. It is conceived as largely relevant to the aspect of internalization of norms, as understood by the authors of this Report. In the words of Cortell and Davis (1996, 456), an international norm's domestic salience largely derives from the legitimacy accorded it in the domestic political context. Usually, "an international rule lacks domestic salience if the state has denied the rule's legitimacy. Such denials might take the form of the state's repeated lack of compliance with the norm's obligations, or its refusal to ratify agreements associated with the international rule".

By internalizing norms, this Report will therefore refer to the situation in which 
international norms receive the state's acknowledgement of the latter's legitimacy.

\section{The European Administrative Space in the context of Europeanization}

\subsection{General concept of the European Administrative Space}

The conceptualization and transformation of the "European Administrative Space" (EAS) into an instrument for evaluating the public administration reforms in the Central and Eastern European countries was developed by SIGMA with the support of the PHARE projects, in response to the European Council's requests regarding the process of accession to the $E U$, formulated at Copenhagen, Madrid or Luxemburg between 1998 and 1999.

According to Fournier $(1998,121)$, the European Administrative "is gradually taking shape. In order to implement Community decisions, the public servants of Member States meet frequently. They get to know each other and trade views and experiences. Patterns of communication develop which have an impact on decision-making, so that common solutions are often found. Officials and experts from European States are becoming used to examining issues jointly, including those having to do with public administration. A European administrative space is emerging with its own traditions which build on but surpass the distinctive administrative traditions of the Union. Administrative reliability, which is necessary for the rule of law, effective implementation of policy and economic development, is one of the key characteristics of this space".

It is obvious that until recently, this administrative space was limited by the national borders of the sovereign states and was the product of the national legislations. The evolutions that followed (gravely marked by the creation and 
enlargement of the European Union that determined the development of the national administrative spaces towards supranational dimensions) lead to the dissolution of the traditional boundaries of sovereignty (Matei and Matei, 2010).

The European Administrative Space is a metaphor with practical implications for Member States and embodying, inter alia, administrative law principles as a set of criteria to be applied by Candidate countries in their efforts to attain the administrative capacity required for EU Membership" (OECD, 1999, 9).

The existence of an European Administrative Space implies that the national public administrations are ruled based on common European principles, norms and regulations, uniformly implemented within a relevant territory (Cardona, 1999, 15). In a summarized view, these principles reflected upon the reliability and predictability of the public administration, its openness and transparency, efficiency and effectiveness and accountability. For the scope of this Report, only the rule of law, openness to the citizens and accountability are to be considered.

\subsection{A possible operationalization of the European Administrative Space}

\subsubsection{Rule of Law}

From a point of view, the rule of law is a "multi-sided mechanism for reliability and predictability" (OECD, 1999, 12). As a principle of the European Administrative Space, it may be rephrased as "administration through law", a principle meant to assure the legal certainty or juridical security of the public administration actions and public decisions.

Other connotations of this principle may be observed when we refer to the opposition of the rule of law in regard to the arbitrary power, cronyism or other 
deviations of the latter that should not be seen as similar to the discretionary power applicable in cases when, within the legal framework, a certain degree of decisional freedom is allowed.

Exercising the discretionary power is limited by the principles of administrative law by means of which the public administration is forced into acting in good trust, follow the public interest, use fair procedures for equal and nondiscriminatory treatment and respect the legal principle of proportionality.

Operationalizing the rule of law is a rather difficult attempt. Taking into consideration the SIGMA papers on the European Administrative Space, the constitutional doctrine (specifically the one relevant to the characteristics of the general, legal norm) as well as the works of other scholars on public administration reforms in Central and Eastern European acceding countries, this report considers that rule of law is quantifiable by means of: 1. law stability and 2. political consensus on the content and implementation procedures of the law.

In what concerns the question of law stability, Central and Eastern European Countries have genuinely known a rather unstable legal framework (Agh, 2005); that actually generated several negative remarks of the European Commission on the progress towards accession to the European Union (The 1998-2004 Regular Reports; The 2005-2006 Monitoring Reports). Therefore, a clear vision of the stability of the law is necessary when discussing the actual put in practice of the rule of law principle.

Political consensus on the final form of the law as well as on the methods for implementing the law is again, a very important factor in the making and maintenance of the rule of law. For the Central and Eastern European Countries, the process of accession to the European Union was overall perceived as a positive one (that giving the very high percentages of Euro-optimists in the Eurobarometers): hence, many of the political factors in the reforming times were in 
agreement on following the exact patterns set forward by the European institutions. That did not necessarily create a true culture for the rule of law, but it at least strengthened its institutional building.

\subsubsection{Openness towards the citizen}

The principle of openness and transparency draw from the reality that public administration is the resonator of the society, assuring the interface with the citizen, the user of its services (Matei and Matei, 2010).

The development of different social phenomena, such as the corruption or maladministration, must be controlled by the society. This urges the administration to become available and to offer sufficient information to the exterior. As such, the openness and transparency refer to these exact attitudes and constitute the necessary instruments for achieving the rule of law and the equality before the law and its representatives. Assuring the openness and transparency, we protect both the public and individual interests.

The reference goes here to the practices imposed by the administrative principles, like in the case of administrative actions being accompanied by statements of reasons, etc. To this, we may add the necessity for the public administration to grant a non-discriminated access to public recordings and recognize the possibility of citizens to address complaints in case of maladministration.

It should be noted that openness gained new characteristics once the public administration was considered to be a public service. In this context, openness becomes acquisitiveness to the citizens or other authorities' initiatives regarding the improvement of public services and their getting closer to the citizen. A new 
concept emerged, largely described by OECD (1996) that of the open administration (Matei and Matei, 2010).

For the scope of this Report, the operationalization of the criterion of "openness to citizens" took into account the issues of discrimination and equality before the law. Deriving from a democratic rule of law, an open public administration was considered to be the one which allowed citizens to participate to the decisionmaking process, without being discriminated on grounds of sex, race, ethnicity, fortune, etc. (lancu, 2010).

Also, considering that in the process of acquiring domestic salience of the principles of administrative openness and transparency, Western practices and principles of administration were delivered as good examples, Eastern countries actually legitimized their changes by creating an ideal picture of the European Union of the 15s. The Report in fact analyzed the potential clash the individual civil servants saw between their administration and that of the European Union's older Member States.

\subsubsection{Self-responsibility of the public administration}

As formulated by OECD (1999), accountability is one of the instruments showing that principles like the rule of law, openness, transparency, impartiality, and equality before the law are respected; it is essential to ensuring values such as efficiency, effectiveness, reliability, and predictability of public administration. As it is described in the doctrine, accountability means that any administrative authority or institution as well as civil servants or public employees should be answerable for its actions to other administrative, legislative or judicial authorities. 
Furthermore, accountability also requires that no authority should be exempt from scrutiny or review by others, which means that, simultaneously or priory, mechanisms for implementation are created.

These mechanisms contain a complex of formal procedures that give a concrete form to the accountability act, as well as supervision procedures that aim to ensure the administrative principle of "administration through law", as it is essential to protect both the public interest and the rights of individuals as well (Matei and Matei, 2010).

In operationalising the principle of accountability, this Report introduced the concept of self-responsibility of the public administration, meaning the capacity the latter shows in acknowledging its behaviors when confronted with the citizens. Closely connected to the principle of openness and transparency, selfresponsibility was defined by means of formal organization, legal procedures and current practices it exhibits in the interaction with the citizens.

The items presented above received a particular attention because of the assumptions this Report made: public employees tend to assume that the responsibility for mal-practices belongs to the heads of their organizations or even to the citizens themselves. The eventual absence of internal evaluation and control of practices would most likely conclude the lack of internal salience of any accountability-related norm. Corruption was another subject of interest in this Report: as argued by Matei, Roşca and Andrei (2009), public administration in transition countries face the doubts of corruption and therefore tend to be considered by their citizens and sometimes, their employees, as less trust-worthy than they actually are. In this respect, the legal procedures aiming at ensuring the existence of accountability mechanisms seem rather not-internalized, than salient. 


\section{The Internalization of the European Administrative Space in Romania}

\subsection{An overview of the public administration in Romania}

According to the ruling of its 2003 Constitution, Romania is a sovereign, independent, unitary and indivisible national state (article 1.1), with a public administration that is organized according to the following general provisions:

1. The state is organized according to the principle of separation and balance of powers (article 4);

2. The Government represents the executive power, is the head of the public administration and is political accountable solely before the Parliament (Chapter 3);

3. „The ordinary and exceptional legislative delegation” enables the Government to adopt rules for primary regulation of the social relations by ordinances and emergency ordinances (article 108);

4. Public administration is organized according to the principles of decentralization, local self-government and devolution of the public services (article 120.1).

Romanian citizens are equal in front of the law and public authorities (article 16.1), might express their thoughts, opinions or beliefs with no fear of censorship (article 30.1,2) and had their rights to petition (article 51.1), apprise the Ombudsman (articles 59) and address a public authority if aggrieved in their legitimate right, in order to get the claimed right acknowledged, annul the act and receive the reparation of the damage suffered (article 52.1). In addition, national minorities have the right to preserve develop and express their ethnic, cultural, linguistic and religious identities guaranteed (article 6.1). 
In Romania, the freedom of the press is recognized (article 30.3), and the individual's right to access any information of public interest is not to be enclosed (article 31.1). Public authorities are asked to correctly inform citizens on public affairs and issues of personal relevance (article 31.2), media - be it private or public - is compelled to give correct information (article 31.4), and the radio and television public services needs to guarantee to important social and political groups the right to antenna (article 31.5).

\subsection{Europeanizing public administration in Romania}

Created for regulating the association between Romania and the European Community, "acknowledging the necessity that the former continues and finalizes, with Community's aid, the transition process to a new political and economic system capable of respecting the rule of law and the human and minority rights, able to exercise the political pluralism based on free and democratic elections and ensure the economic liberalization for developing a market economy", the Europe's Agreement ${ }^{4}$ was the first instrument of formal national contact with the enlargement process. "[...] For Romania, the Union is firstly a door to a balanced and harmonious structure, which organizes the continental micro and macrocosmos under the European civilization flag, a common house where each member keeps its identity (in DOC/97/18)"

The crystallization of the Europeanization's mechanisms for Romania, as a candidate country happened in 1999, at Helsinki, when: "Determined to lend a positive contribution to security and stability on the European continent and in the light of recent developments as well as the Commission's reports, the European Council has decided [...] to begin negotiations with Romania [...] on the conditions for [its] entry into the Union and the ensuing Treaty adjustments." (Conclusions, point I10).

\footnotetext{
${ }^{4}$ Ratified by Law no. 20 of $6^{\text {th }}$ of April 1993 and published in the Official Gazette of Romania, part I, no. 73/12 April 1993.
} 
From this moment on, it become clear the impact of the Union on the Romanian domestic order; it can be also quantified thanks to the three classical, and already mentioned institutional levers of the Europeanization: the acquis communautaire, the pre-accession financial assistance and the institutional twinning.

\subsubsection{Acquis communautaire as Europeanization lever}

Between 2000 and 2004, Romania was involved in a constant process of negotiation of the acquis (table 1 ).

Table 1: Evolution of the negotiation process

\begin{tabular}{|l|c|l|}
\hline In ... & Romania opened $\ldots .$. & And closed.... \\
\hline 2000 & 9 chapters & $\begin{array}{l}6 \text { chapters: Statistics; Small and Medium Size Enterprises; } \\
\text { Science and Research; Education and Professional } \\
\text { Training; External Relations; External and Common } \\
\text { Security Policy }\end{array}$ \\
\hline 2001 & 8 chapters & $\begin{array}{l}\text { 3 chapters: Law of Commercial Societies; Fishery; } \\
\text { Consumer and Health Protection }\end{array}$ \\
\hline 2002 & 13 chapters & $\begin{array}{l}\text { 6 chapters: Economic and Monetary Union; Social Policy; } \\
\text { Industrial Policy; Telecommunications and IT; Culture and } \\
\text { AudioVisual; Union }\end{array}$ \\
\hline 2003 & - & $\begin{array}{l}5 \text { chapters: Free Movement of Persons; Free Movement of } \\
\text { Capital; Transportation Policy; Taxes; Financial Control }\end{array}$ \\
\hline & - & $\begin{array}{l}\text { 9 chapters: Free Movement of Services; Competition } \\
\text { Policy; Agriculture; Energy; Regional Policy and } \\
\text { coordination of structural elements; Environment; Justice } \\
\text { and Home Affairs; Financial and Budgetary dispositions; } \\
\text { Others }\end{array}$ \\
\hline
\end{tabular}




\subsubsection{Pre-accession funds as Europeanization lever}

1. $\mathrm{PHARE}^{5^{19}}$ : Between 2000 and 2003, Romania received more than 1 billion Euros to fulfill the political and economic criteria, strengthen the administrative capacity, respect the obligations deriving from the acquis and accomplish the economic and social cohesion (via national programs of cross border cooperation and specific measures). Between 2004 and 2006, following a strategic multiannual approach, the EU's financial assistance was targeted to specific programs for key sectors (public administration, public finance, agriculture, environment, justice, border management, minorities, economic and social cohesion) and neighboring programs with Republic of Moldavia, Serbia and Montenegro and Ukraine.

2. ISPA: Between 2000 and 2006, Romania received from ISPA, approximately 240 de million Euros per year. During 2000 and 2003, for instance, Romania closed 40 financial memorandums with ISPA comprising an amount of 1446 million Euros EU funds, that is over $70 \%$ of the total amount provided within the forementioned time frame.

3. SAPARD: The National Plan for Agriculture and Rural Development represented the basis for implementing SAPARD in Romania and was approved in December 2000 and revised in August 2003. It includes an amount of over 2 billion Euros (public and private expenses), of which 1.113,4 million is the European Union's share. The four regrouped eligible priorities taken into consideration for Romania's case were: a) development of production and delivery of agricultural and fishery products; b) development of rural infrastructure; c) development of rural economy (investments in firms with agricultural, economic diversification and forestry profiles); d) development of human resources (improvement of professional training, technical assistance, including studies to support and monitor the program, information and publicity

\footnotetext{
5 Source: Official website of the Ministry of External Affairs: http://ue. mae.ro/index.php?lang=ro\&id=199, accesed on 01.09.2006.
} 
campaigns).

\subsubsection{Institutional twining as Europeanization lever}

Twinning programs in Romania were financed by PHARE. According to the European Union data (available online in the information brochure: Twinning, 2006), between 1998 and 2005, Romania was the Candidate country with the largest number of twinning programs developed 191 (out of 1110 possible).

Thus the European Union also counted in Romania's case as a candidate country. Thanks to the 31 negotiation chapters, the institutional models that were suggested as good governing instruments, the financial and technical assistance it received for reforming matters, the periodical monitoring and the consultancy and twinning sessions, Romania was indeed a "consumer" of European goods.

Starting with January 2007, Romania becomes, theoretically speaking, a "producer" of Europeanization: in what way this will cause further changes to the national administrative structures is the subject of another possible scientific investigation.

\subsubsection{Public Administration under Reform. Inputs on the rule of law, openness and self-responsibility}

In order to assess to what extent the formal principles of the European Administrative Space were consolidated, this Report makes use of the exterior scrutiny provided for by the European Commission between 1998-2007 (Matei and lancu, 2010; lancu, 2010).

In fact, it was during this timeframe that Romania's progress to the European Union was under close assessment; giving then that the European acquis contained specific references on good enough governance (as advocated in lancu, 2010) and that during Romania's candidature to the European Union 
(1998-2007), and considering that the Regular (Monitoring) Reports ${ }^{6}$ were elaborated by the European Commission on the basis of real decisions undertaken by Romanian authorities, international treaties and conventions already ratified and effective measures for implementing reforms, the authors agreed to consider the Regular and Monitoring Reports on Romania's progress toward accession within the time frame: 1998-2007 adequate sources of information for our research.

To this end, the documentary investigation of RR and MR on Romania (19982007) (English version) concluded that:

1. Rule of law, a principle fundamental to the political criteria, was considered present in Romania's case in all the reports made public by the European Commission (RR 1998:8; RR 1999:11; RR 2000:14; RR 2001: 16; RR 2002:21; RR 2003:14; RR 2004:15). Its consolidation however represented a constant preoccupation for the Commission, the latter giving notice of the need to clearly separate the legislative from the executive by reducing the number of Governmental simple or emergency ordinances (in RR 1998:8; RR 1999:12; RR 2000:14; RR 2002:129; RR 2003:16; RR 2004:15). It also raised doubts on the efficacy of parliamentary scrutiny when the Government made use of so many ordinances (RR 2003:14; RR 2004:16).

2. Openness and transparency: According to RR 1998, the Romanian administrative system was characterized by administrative weakness, secret of public information and deterioration of equitable application of law (RR 1998:9). Still, adopting the National Strategy for Informatisation and fast implementation of the information society ${ }^{7}$ (in February 1998) appeared as a possible step in increasing the accessibility and efficiency of the public administration (RR 1998:26). In 1999, Commission positively noticed the legal development of the

\footnotetext{
${ }^{6} \mathrm{RR}$ and $\mathrm{MR}$ for future references.

7 Adopted by Decision no.58/1998 on approval of the National Strategy, and published in the Official Gazette of Romania, no.93/27.02.1998.
} 
freedom of expression, making however a point when advocating against the latter's limitations (the case of media censorship was then in debate: RR 1999:17; RR 2000:21). Still on the issue of openness, the Commission suggested the need to increase the visibility of the Ombudsman (RR 1999:17) and the non-discrimination of Roma population in local policy making (RR 1999:19). Still in 1999 and again in connection to the preference-holders participation to policy making, the creation of the Economic and Social Council in 1997 and development of a social dialogue legal framework was positively noticed (RR 1999:18, 46, 51). In regard to the transparency as a principle of local public administration, the Commission enumerated it amongst the prerequisites of an efficient financial management (RR 2000:16-17, 30 and RR 2004:39). However, in direct reference to local policy making (RR 2000:31) and privatization of public enterprises (RR 2000:49), it was considered absent. In the same vein, still in 2000 , the free access to judicial documentation was considered to be restricted (RR 2000:16, but also RR 1999:13).

The principle of participation was at its turn noticed by the Commission but only in connection to the consumer protection and health system, the need for preference-holders involvement in central and local policy making being then seen as imperative (RR 2000:73). In 2001, introducing regulations on eadministration $^{8}$ was considered a positive evolution of the administrative system towards openness and transparency (RR 2001:19); still, the absence of norms implementing the constitutional right to information ${ }^{9}$, and ensuring the transparency of local fiscal policies was considered a major administrative weakness (RR 2001:22; 35). One year later, the Commission advocated for the consolidation of the transparency of policy making processes (RR 2002:22), although progress in this regard was made once the law on free access to

\footnotetext{
${ }^{8}$ Government Decision no.1006/2001, as published by the Official Gazette of Romania no. $660 / 19.10 .2001$.

${ }^{9}$ Article 31 of the initial version of the Constitution of Romania (1991).
} 
information was enacted $^{10}$ (RR 2002:23,27,32; RR 2003:26). On the same topic of free access, with special reference to civil service, RR 2003 reaffirms the positive evolution of Law no. $188 / 1999^{11}$ on civil service (RR 2003:15) and, in direct connection to the law on transparency of the decision-making process, the Commission concluded that: "if implemented, that legislation [Law no.52/2003] could significantly improve the decision making process" (RR 2003:16-17). Same opinions are to be found in RR 2004, where only additional references to local implementation of the quoted legal texts were to be found (RR 2004:16). Still on the local level, RR 2004 recommended that the allocation of resource transfers to local authorities to be made in a transparent manner (RR 2004:18).

3. Self-responsibility: For this Report, self-responsability raises attention only in what concerns the public administration's human resources. In this respect, RR 1999 (p. 56) discussed of the need of regulating accountability, impartiality and legality of civil service. One year later, positive notes were being made once the Civil Service Statute was enacted (RR 2000:16). However, the lack of specific regulations allowing the access to public information continued to create problems to the overall real accountability of the administrative authorities (RR 2001:22). In contrast, the creation of the Ombudsman and its activity to hold accountable all administrative authorities that might have infringed preferenceholders rights and liberties was seen as a good indicator for enhancing the public administration's capacity to adequately answer to the received inputs (RR 1998:9; RR 1999:17; RR 2000:22; RR 2001:23; RR 2002:29; RR 2003:22-23; RR 2004:24). In addition, RR 2004 recognized that: "free access to public information, proved to be an important mechanism promoting public accountability" (p. 26) and called for an institution to hold the explicit responsibility in effectively implement the law on free access to public information.

\footnotetext{
${ }^{10}$ Law no. 544/2001, as published by the Official Gazette of Romania no. $663 / 23.10 .2001$. This legal text however has so far known several amendments.

${ }_{11}$ Law on Civil Servant Statute initially published in the Official Gazette of Romania no. $600 / 08.12 .1999$. This text was severely and continuously amended, and in May 2007 republished (Official Gazette no. 365/29.05.2007. Hence, no alterations were being added.
} 


\section{The European Administrative Space in Romania. Empirical evidences on its internalization}

\section{An Overview}

The socio-statistic research elaborated for the scope of this Report was based on a representative sample of Romanian civil servants and public employees from the central and local public administration and other areas of the public sector, such as education, health, etc.

\subsubsection{Description of the sample}

The research was conducted based on a questionnaire (in Annex 1) that was distributed in March 2008 to 634 subjects, of which 592 offered valid inputs. According to the working place of the subjects, the following distribution may be observed (table 2).

Table 2. Distribution based on working place of the subjects

\begin{tabular}{|l|l|l|l|l|l|}
\hline Organization & Nr. & $\%$ & Organization & Nr. & $\%$ \\
\hline Government / Ministries & 72 & 12.2 & Local Councils & 40 & 6.8 \\
\hline $\begin{array}{l}\text { Organizations under the } \\
\text { supervision of the Government }\end{array}$ & 59 & 10.0 & City-halls & 106 & 17.9 \\
\hline Autonomous organizations & 22 & 3.7 & Education, health, etc. & 78 & 13.2 \\
\hline Deconcentrated services & 11 & 1.9 & Tertiary sector & 89 & 15.1 \\
\hline Decentralized services & 21 & 3.5 & Students / master graduates & 80 & 13.5 \\
\hline $\begin{array}{l}\text { County councils / Prefectural } \\
\text { offices }\end{array}$ & 13 & 2.2 & & & \\
\hline
\end{tabular}

Table 2 clearly shows that $22,2 \%$ of the interrogated subjects are civil servants employed in the central public administration, $5,4 \%$ work as civil servants in the territorial administration and $26,9 \%$ in the local public administration. The current developments present in the Romanian society and the implementation of the European Administrative Space concept have determined the presence, in the 
sampling, of representatives of the tertiary sector. This is because the latter are included in the delivery of services of public interest, organized as a consequence of the privatization of former public services or the creation of public-private partnerships $(15,1 \%)$, autonomous organizations $(3,7 \%)$ and the quaternary sector $(26,7 \%)$. A closer look on the sampling this Report uses is provided for by Table 3 .

Table 3. Distribution of the sampling on age and sex groups

\begin{tabular}{|l|l|l|l|l|l|l|}
\hline Age groups & Nr. & \% & Women & \% & Men & \% \\
\hline 18-25 years & 64 & 10.8 & 33 & 52.2 & 31 & 47.8 \\
\hline $26-35$ years & 213 & 36.0 & 121 & 57.0 & 92 & 43.0 \\
\hline $36-45$ years & 251 & 42.4 & 154 & 61.2 & 97 & 38.8 \\
\hline $46-55$ years & 53 & 9.0 & 32 & 61.4 & 21 & 38.6 \\
\hline $56-65$ years & 8 & 1.4 & 3 & 44.4 & 5 & 55.6 \\
\hline Over 65 years & 3 & 0.5 & 2 & 66.6 & 1 & 33.4 \\
\hline Total & 592 & 100 & 345 & 58.5 & 247 & 41.5 \\
\hline
\end{tabular}

Based on data presented above, several indicators for characterizing this distribution were calculated:

1. the mean age of the sampling is 40,2 years.

2. the variance of the sampling is 0,785 , and standard deviation is 0,886 .

3. the Kurtosis coefficient is 0,707 , while the Skewness coefficient is 0,35 , which shows an asymmetrical, flat distribution with a positive Skewness.

4. the coefficient for homogeneity of the sampling is $15 \%$, which denotes that the series of attached data is relatively homogenous.

Figure 1 presents the histogram associated to the series of data. 
Figure 1: Histogram of the age distribution

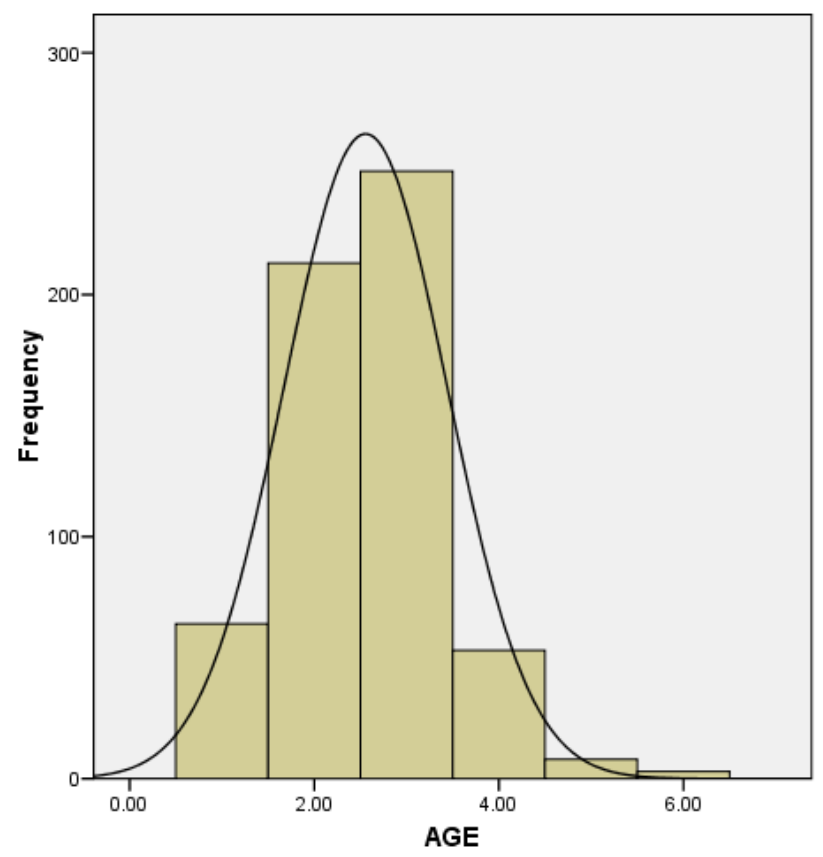

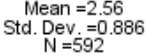

Seniority may be considered an important element for the consistency of the answers received. Table 4 presents the distribution of the sampling based on general seniority and seniority in the current working place.

Table 4. Distribution of the sampling on seniority

\begin{tabular}{|l|c|c|c|c|}
\hline \multicolumn{3}{|c|}{ General seniority } & Seniority in the current working place \\
\hline Seniority groups & $\mathrm{Nr}$. & $\%$ & $\mathrm{Nr}$. & $\%$ \\
\hline 0 years & 12 & 2.0 & 79 & 14.2 \\
\hline 1-5 years & 148 & 25.0 & 222 & 40.0 \\
\hline 6-10 years & 162 & 27.4 & 142 & 25.6 \\
\hline 11-20 years & 161 & 27.2 & 87 & 15.7 \\
\hline Over 20 years & 109 & 18.4 & 25 & 4.5 \\
\hline TOTAL & 592 & 100 & 555 & 100 \\
\hline
\end{tabular}

Table 4 and Figures 2.a and 2.b. offer the following conclusions:

1. the mean of general seniority is 7,15 years, and of seniority in the current working place is of 3,16 years.

2. the variance for the two characteristics is 1,219 ad 1,117 respectively; standard deviation is 1,104 and 1,056 respectively. 
3. the Skewness coefficients of 0,010, and 1,449 respectively, show a rather symmetrical distribution for the general seniority and an asymmetry, with a positive distortion for the seniority at the current working place. In both situations the Kurtosis coefficients $(-1,065$ and $-0,451$ respectively) suggest a flat distribution for the first one, and a picked distribution for the second one.

4. the homogeneity coefficient varies between $7,84 \%$, respectively $10,44 \%$ which place the series of data in the category of the relatively homogenous series.

In Figure 2.a respectively Figure 2.b the histograms of the two distributions are presented.

Figure 2.a. Histogram of the distribution on general seniority

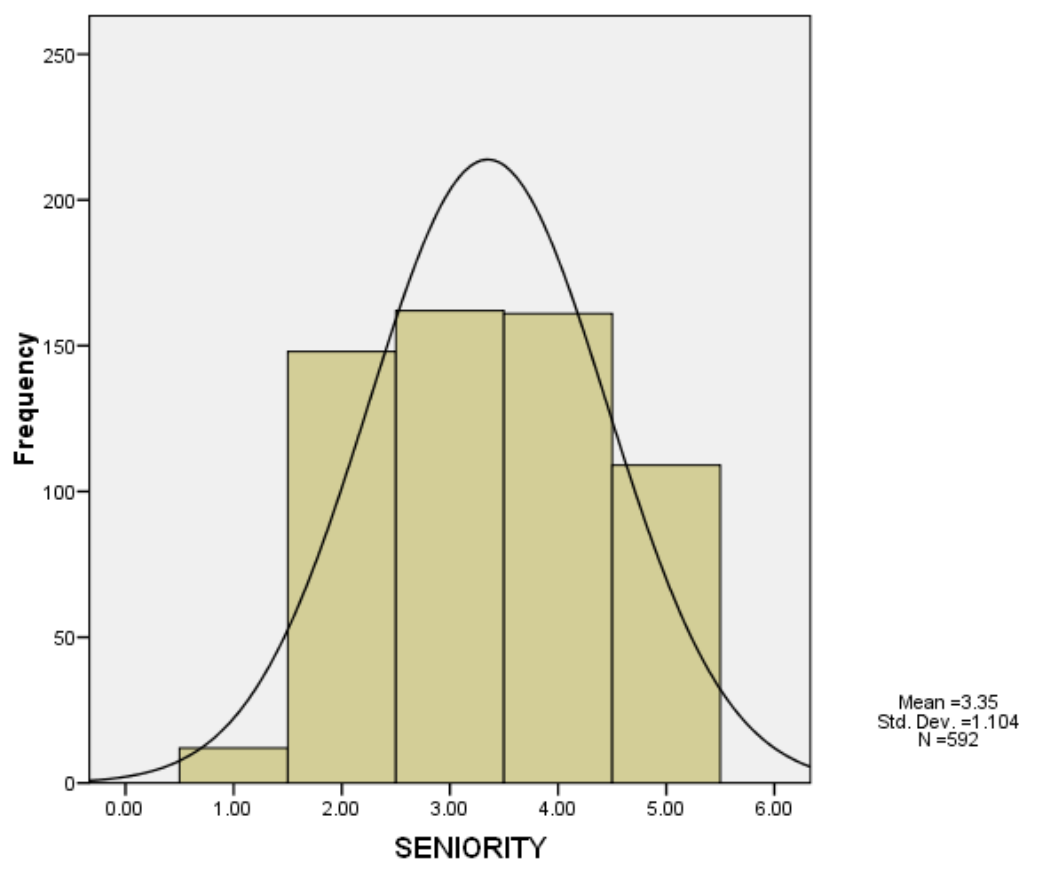


Figure 2.b. Histogram of the distribution on seniority at the current working place

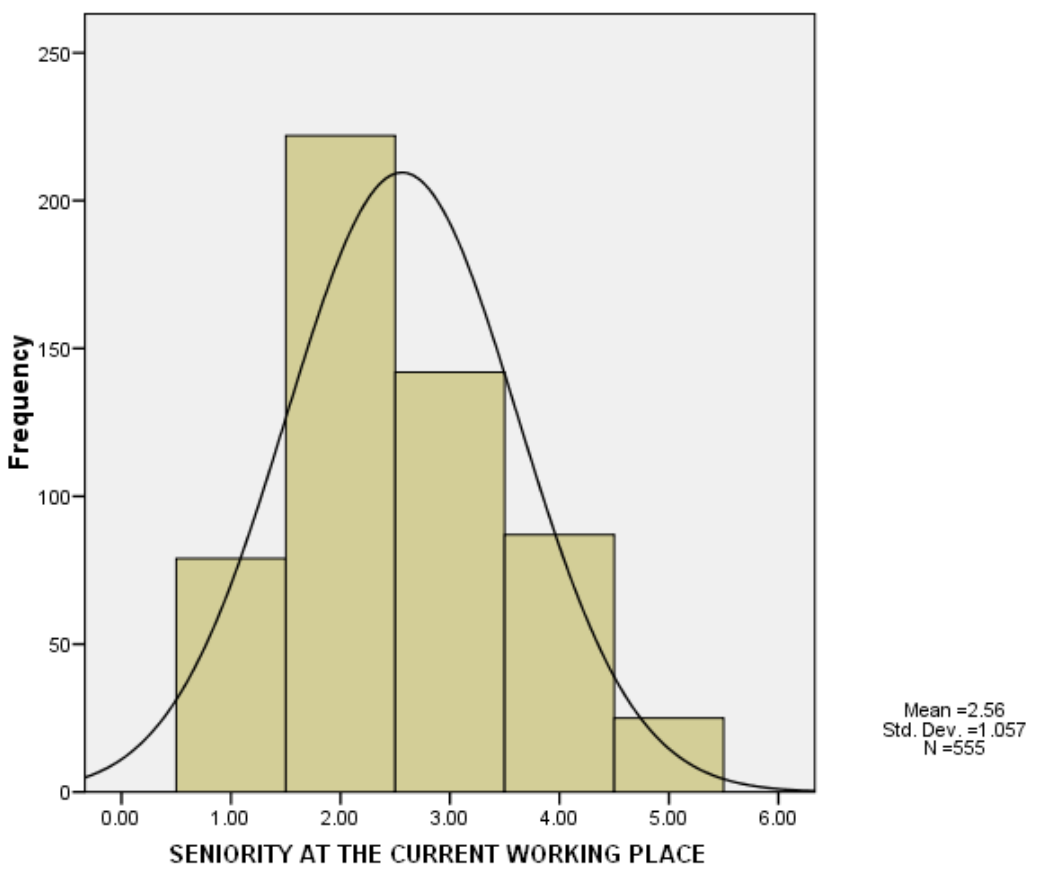

Considering the specific structure of the occupations in the public sector and taking into account the principles of the European Administrative Space, Table 5 shows the distribution of the sampling based on the categories of civil servants, as well as the modalities of recruiting for contracting personnel.

Table 5. Distribution of the sampling on positions occupied in the system

\begin{tabular}{|l|l|l|l|l|l|l|l|c|}
\hline \multirow{2}{*}{ Category } & \multirow{2}{*}{ Nr. } & \multirow{2}{*}{$\%$} & \multicolumn{5}{|c|}{ Employed by means of: } \\
\cline { 4 - 9 } & & & \multicolumn{3}{|c|}{ Contest } & \multicolumn{2}{c|}{ Appointment } & \multicolumn{2}{c|}{ Other } \\
\cline { 4 - 9 } & & & Nr. & $\%$ & Nr. & $\%$ & Nr. & $\%$ \\
\hline $\begin{array}{l}\text { Management civil } \\
\text { servant }\end{array}$ & 88 & 14.9 & 88 & 100 & - & - & - & - \\
\hline $\begin{array}{l}\text { Operational civil } \\
\text { servant }\end{array}$ & 205 & 34.6 & 205 & 100 & - & - & - & - \\
\hline Contractual employer & 131 & 21.9 & 88 & 67.2 & 41 & 31.3 & 2 & 1.5 \\
\hline No working contract & 80 & 13.5 & - & - & - & - & - & - \\
\hline No answer & 88 & 15.1 & - & - & - & - & - & - \\
\hline
\end{tabular}

Taking into consideration only the valid answers, one observes that the sample was formed from 293 civil servants, 131 contractual employees and 80 students, 
master students in programs dedicated to public administration. The sample does not include high civil servants, taking into consideration the political implications that category particularly exhibits and the absence of relevant experience for the civil service.

\subsubsection{Structure of the questionnaire}

The questionnaire is structured on three major themes, correlated to the basic principles of the European Administrative Space: rule of law, openness towards citizens and self-responsibility of the public administration (table 6).

Table 6. Characteristics of the questionnaire

\begin{tabular}{|l|l|c|c|c|}
\hline Nr. & Major themes investigated & $\begin{array}{l}\text { Nr. of closed } \\
\text { questions }\end{array}$ & $\begin{array}{l}\text { Nr. Of primary } \\
\text { variables }\end{array}$ & Open questions \\
\hline 1 & Rule of law & 5 & 20 & 1 \\
\hline 2 & Openness towards citizens & 4 & 27 & - \\
\hline 3 & $\begin{array}{l}\text { Self-responsibility of the } \\
\text { public administration }\end{array}$ & 6 & 41 & - \\
\hline
\end{tabular}

The variables defined and used in the questionnaire are to be found on three levels of aggregation, in connection to the objectives of investigation as formulated for the three major themes. In order to evaluate the quantitative characteristics associated to each primary variable, we used the report scales with values in the following set $\{1,2,3,4,5\}$ or $\{0,1\}$. The values of the scales are equidistant. The primary variables are directly defined based on the questions of the questionnaire. The primary variables were grouped in relation to the connections set between them by the relevant doctrine. The aggregation module was established in relation to the common statistical methods.

Usually, we calculated the level of values and (or) the descriptive indicators that characterize the mean, the variance, the asymmetry and skewness for the majority of primary and aggregated variables 


\subsection{Determining the empirical characteristics of the internationalization of the principles of the European Administrative Space}

As previously mentioned in sections 3.2. and subsection 3.3.1.2., the public administration doctrine offered a characterization of the principles of European Administrative Space based on three themes. These themes are presented in the remaining of this Report.

\subsubsection{Rule of law (Rulelaw)}

The Rulelaw (q1) variable is conceived as level 3 aggregated variable obtained from the aggregation of level 2 variables. They refer to: the legislative sustainability (SusLeg - q11), elimination of deficiencies in the national administrative system (EIDef - q12), the causes of deficiencies in applying the administrative ruling (CausDef - q13), the necessary conditions for the welfare of administrative activities (NecCond - q14), as well as the necessary conditions for stabilizing the legislative framework (NecStab - q15).

\section{a) The legislative sustainability (SusLeg)}

The variable offers an empirical image of the level of sustainability of the legal and normative framework of the public administration. It is formed by aggregating four primary variables which quantify the perception on stability (q11a), clarity (q11b), complexity (q11c) and comprehensiveness (q11d). The results of the statistical analysis employed are presented in Table 7.

Table 7. Statistical characteristics of the primary variable SusLeg

\begin{tabular}{|l|l|l|l|l|l|l|l|l|}
\hline & N & Mean & Std. & Variance & \multicolumn{2}{|c|}{ Skewness } & \multicolumn{2}{|c|}{ Kurtosis } \\
\hline & Statistic & Statistic & Statistic & Statistic & $\begin{array}{l}\text { Statist } \\
\text { ic }\end{array}$ & $\begin{array}{l}\text { Std. } \\
\text { error }\end{array}$ & $\begin{array}{l}\text { Statistic } \\
\text { error }\end{array}$ \\
\hline
\end{tabular}




\begin{tabular}{|c|c|c|c|c|c|c|c|c|}
\hline Stability & 575 & 2.4435 & 1.32512 & 1.756 & .156 & .102 & -1.373 & .203 \\
\hline Clarity & 575 & 2.4417 & 1.27274 & 1.620 & .177 & .102 & -1.183 & .203 \\
\hline Complexity & 575 & 2.7983 & 1.64571 & 2.708 & -.009 & .102 & -1.730 & .203 \\
\hline $\begin{array}{l}\text { Comprehen } \\
\text { siveness }\end{array}$ & 575 & 2.1739 & 1.21733 & 1.482 & .524 & .102 & -.937 & .203 \\
\hline $\begin{array}{l}\text { Valid N } \\
\text { (listwise) }\end{array}$ & 575 & & & & & & & \\
\hline
\end{tabular}

The statistical means situate the social perception evenly equal for stability and clarity of the legal framework $(2,44)$, slightly higher for complexity $(2,80)$ and slightly lower for comprehensiveness $(2,17)$. The proportion of those who do not know or do not answer is high for each variables (q11a - 41\%, q11b - 37,7\%, $q 11 c-42,6 \%, q 11 d-44,5 \%)$. This, correlated with the mean, variance and the internalization, proves a low level of the knowledge on the European Administrative Space principles. Also, it is to be noted that the ratio of those appreciating the mentioned characteristics (with the exception of complexity) is low, respectively $24,9 \%$ for stability, $20,7 \%$ for clarity and $15,3 \%$ for comprehensiveness. The complexity represents the most appreciated characteristic, the percentage, over the mean, being $48,7 \%$.

Analyzing the four variables considering the statistical correlation, as it results from Table 8, they are situated between 0,307 and 0,519.

Table 8. Pearson Correlation for the primary variables of SusLeg

\begin{tabular}{|c|c|c|c|c|c|}
\hline & & Stability & Clarity & Complexity & Comprehensiveness \\
\hline \multirow{7}{*}{ Stability } & $\begin{array}{c}\text { Pearson } \\
\text { Correlation }\end{array}$ & 1 & $.482^{\star * *}$ & $.331^{* * *}$ & $.505^{\star * *}$ \\
\cline { 2 - 6 } & $\begin{array}{c}\text { Sig. (2- } \\
\text { tailed) }\end{array}$ & & .000 & .000 & .000 \\
\cline { 2 - 6 } & $\mathrm{N}$ & 575 & 575 & 575 & 575 \\
\hline \multirow{7}{*}{ Clarity } & $\begin{array}{c}\text { Pearson } \\
\text { Correlation }\end{array}$ & $.482^{* * *}$ & 1 & $.307^{* * *}$ & $.519^{* *}$ \\
\cline { 2 - 6 } & $\begin{array}{c}\text { Sig. (2- } \\
\text { tailed) }\end{array}$ & .000 & & .000 & .000 \\
\cline { 2 - 6 } & $\mathrm{N}$ & 575 & 575 & 575 & 575 \\
\hline Complexity & Pearson & $.331^{* *}$ & $.307^{* *}$ & 1 & $.458^{\star *}$ \\
\hline
\end{tabular}




\begin{tabular}{|c|c|c|c|c|c|}
\hline & Correlation & & & & \\
\hline & $\begin{array}{l}\text { Sig. (2- } \\
\text { tailed) }\end{array}$ & .000 & .000 & & .000 \\
\hline & $\mathrm{N}$ & 575 & 575 & 575 & 575 \\
\hline \multirow[t]{3}{*}{ Comprehensiveness } & $\begin{array}{c}\text { Pearson } \\
\text { Correlation }\end{array}$ & $.505^{\star *}$ & $.519^{* *}$ & $.458^{\star *}$ & 1 \\
\hline & $\begin{array}{l}\text { Sig. (2- } \\
\text { tailed) }\end{array}$ & .000 & .000 & .000 & \\
\hline & $\mathrm{N}$ & 575 & 575 & 575 & 575 \\
\hline
\end{tabular}

${ }^{* *}$ Correlation is significant at the 0.01 level (2-tailed).

All variables present positive correlations and their correlation coefficients are medium. Based on these findings, we will determine the aggregation coefficients for SusLeg (q11), as uniformed means of the Pearson correlation coefficients. As such, we will obtain the variable:

SusLeg: $N->\{1,2,3,4,5\}$

SusLeg $=0,253 q 11 a+0,251 q 11 b+0,211 q 11 c+0,285 q 11 d$.

Table 9 presents the characteristics of the SusLeg variable.

Table 9. Statistical descriptors for SusLeg variable

\begin{tabular}{|l|l|l|l|l|l|l|l|l|}
\hline & $\mathbf{N}$ & Mean & Std. & Variance & \multicolumn{2}{|c|}{ Skewness } & \multicolumn{2}{|l|}{ Kurtosis } \\
\cline { 2 - 9 } & Statistic & Statistic & Statistic & Statistic & Statistic & $\begin{array}{l}\text { Std. } \\
\text { Error }\end{array}$ & Statistic & $\begin{array}{l}\text { Std. } \\
\text { Error }\end{array}$ \\
\hline SusLeg & 575 & 2.441 & 1.02317 & 1.047 & .367 & .102 & -.989 & 203 \\
\hline $\begin{array}{l}\text { Valid N } \\
\text { (listwise) }\end{array}$ & 575 & & & & & & & \\
\hline
\end{tabular}

- the statistical analysis for SusLeg shows us a variable with a mean of 2,44 and a variance of 1,047 which strengthens the already presented conclusions on the law level of internalization of the characteristics which describe the sustainability of the current legislative framework. 
- The homogeneity coefficient is of 10,64 which corresponds to a relative homogenous variable. However, it is of notice that the level of responses between 1 and 2 represents $47 \%$.

- The Skewness coefficient $(0,367)$ shows an almost symmetrical, sharp and lightly negatively distorted variable.

Figure 3. Histogram of SusLeg variable

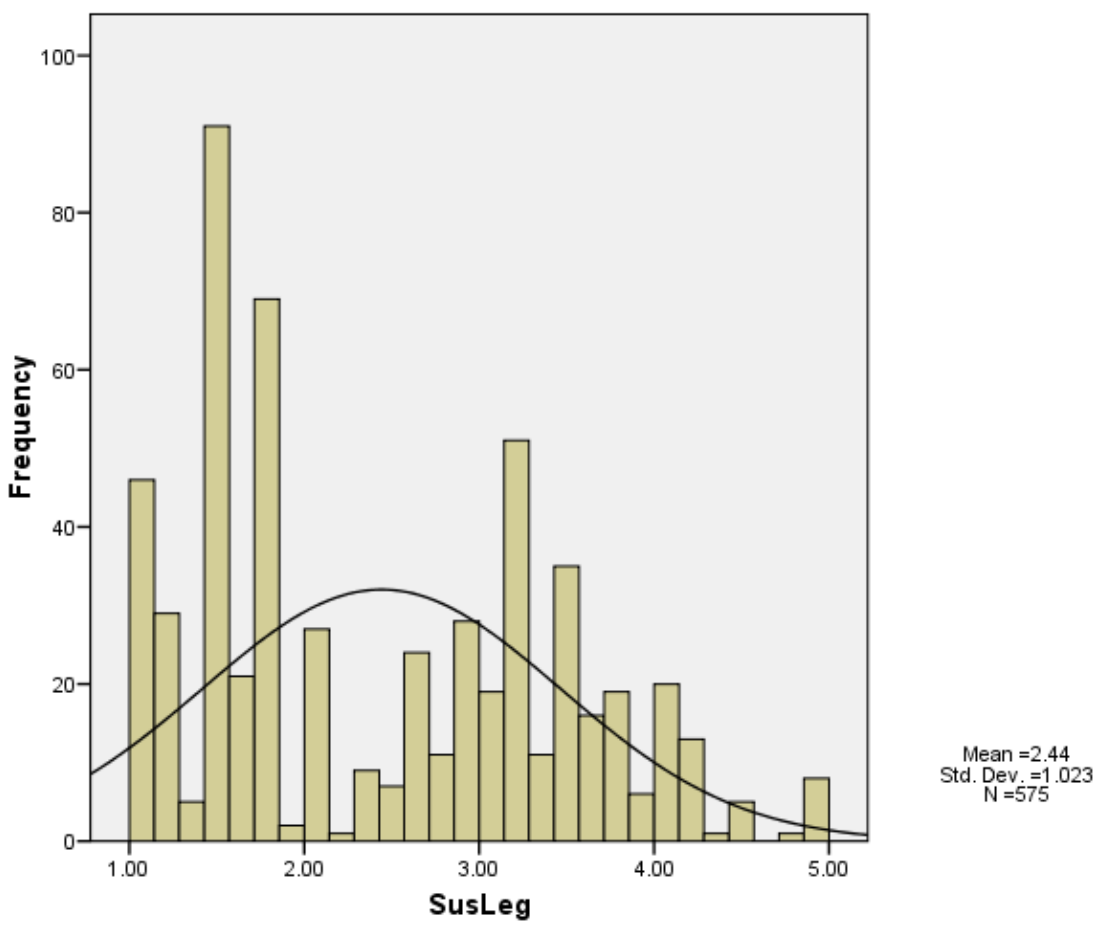

b) Eliminating the deficiencies in the national administrative system (EIDef)?

The variable attempts to identify the ways to eliminate the deficiencies in the national administrative system, suggesting as premises for analysis: the internal political consensus ( $q 12 a$ ), the control of the legality of administrative acts (q12b), the speeding of the procedures aimed at adopting the law (q12c) and the control of the law application (q12d).

According to the importance granted by the answers, the four characteristics are prioritized as in Table 10. 
Table 10. Hierarchy of options on eliminating the deficiencies of the national administrative system

\begin{tabular}{|l|l|l|}
\hline Variable & Options & Mean \\
\hline Control (q12b) & 323 & 0.56 \\
\hline Supervision $(\mathrm{q} 12 \mathrm{~d})$ & 236 & 0.41 \\
\hline Speeding & 234 & 0.40 \\
\hline Consensus & 221 & 0.38 \\
\hline
\end{tabular}

The most notable observation is that the majority of answers advocate in favor of a rigorous control of the legality of administrative acts and almost equally they indicate the rest of the methods.

Also, one may observe that the answers generally tend to choose a complex of alternatives aimed at the good functioning of the national administrative system.

The analysis of several relevant characteristics of the four variables indicate a majority option $(56,2 \%)$ towards the need of control of decision-making process. The rest of variables are equally representative $(38,4 \%-41 \%)$. The Skewness Coefficient close to 0 in a rather equal value $(0,237$ - 0,247) indicates a symmetrical distribution of the answers. Table 11 gives account to these empirical findings.

Table 11. Statistical characteristics of the internal political consensus (q12a), the control of the legality of administrative acts (q12b), the speeding of the procedures aimed at adopting the law $(q 12 c)$ and the control of the law application (q12d).

\begin{tabular}{|l|l|l|l|l|l|}
\hline \multicolumn{1}{|c|}{ Characteristics } & \multicolumn{1}{|c|}{$\mathbf{N}$} & \multicolumn{1}{|c|}{ Mean } & Variance & Skewness & \multicolumn{1}{c|}{ Sum } \\
\cline { 1 - 3 } Variables & & & & & \\
\hline q12a & 575 & 0.3843 & 0.247 & 0.477 & 221 \\
\hline q12b & 575 & 0.5617 & 0.247 & -0.250 & 323 \\
\hline
\end{tabular}




\begin{tabular}{|l|l|l|l|l|l|}
\hline q12c & 575 & 0.4070 & 0.242 & 0.380 & 234 \\
\hline q12d & 575 & 0.4104 & 0.242 & 0.365 & 236 \\
\hline
\end{tabular}

A more conclusive image on the answers is offered by calculating the frequencies for a sum variable of the four independent variables (Table 12). The majority of answers (51,5\%) opts for several concomitant actions leading to an increase of the efficiency of the decision-making process.

Table 12. Cumulative frequencies of the variables

\begin{tabular}{|l|l|l|l|l|}
\hline $\mathbf{q 1 2 a + q 1 2 b + q 1 2 c + q 1 2 d}$ & Frequency & Percent & Valid Percent & $\begin{array}{l}\text { Cumulative } \\
\text { Percent }\end{array}$ \\
\hline 0.00 & 25 & 7.0 & 4.3 & 4.3 \\
\hline 1.00 & 254 & 15.3 & 44.2 & 48.5 \\
\hline 2.00 & 168 & 29.2 & 29.2 & 77.7 \\
\hline 3.00 & 88 & 15.3 & 15.3 & 93.0 \\
\hline 4.00 & 40 & 7.0 & 7.0 & 100 \\
\hline
\end{tabular}

An analysis of the correlations of the four variables indicate the absence of any correlation (with the exception of one positive and significant - 0,146-0,01 level, for $\mathrm{q} 12 \mathrm{~b}$, control and $\mathrm{q} 12 \mathrm{~d}$, supervision). However, a combination of the four variables seems possible, given the data provided in Table 13.

In this context, we form the aggregate variable:

q12 : $N$-> [0,5]

$q 12=(q 12 a+q 12 b+q 12 c+q 12 d)^{*} 5 / 4$

Table 13. Descriptive statistics for variable q12

\begin{tabular}{|l|l|l|l|l|l|l|l|}
\hline $\mathbf{N}$ & Mean & Std. & Variance & \multicolumn{2}{c|}{ Skewness } & \multicolumn{2}{c|}{ Kurtosis } \\
\hline Statistic & Statistic & Statistic & Statistic & Statistic & Std. error & Statistic & Std. error \\
\hline 575 & 2.2043 & 1.24545 & 1.551 & .647 & .102 & -.274 & .203 \\
\hline
\end{tabular}


Table 13 offers an image for the following:

- A low homogeneity, due to a high variance $(1,551)$ of the series of data obtained by aggregation of the four variables.

- The series of data presents a positive Skewness $(S=0,647)$, and its shape is flattened (as observed in Figure 4. Also, it may be noted the significant deviation from normality.

Figure 4. Histogram of series q12.
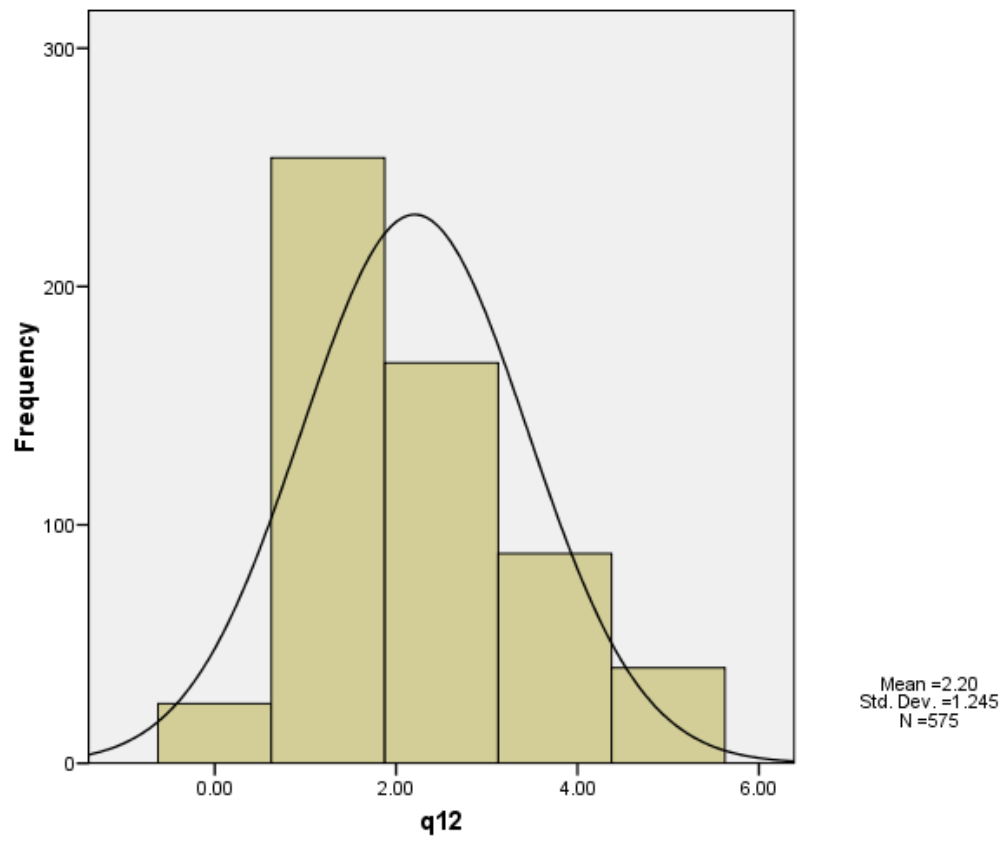

c) Enforcing the administrative rules

The assessment designed from the viewpoint of own professional experiences in strengthening the enforcement of administrative rules takes into account four independent variables. Defining these variables starts from the existent situation in the Romanian public administration, one that suggests the absence of the law and the instruments and procedures needed for its implementation as well as the methodological inconsistency. In this context, the four variables refer to the concomitant existence of several contradictory legal procedures (q13a), and 
methodological and procedural provisions (q13b), and the absence of a proper legislative framework for driving an efficient administrative action (q13c) and of a methodology for the proper application of the law (q13d).

The analysis of the statistical characteristics of the four variables point a high percentage $(48,35 \%)$ of contradictory legal provisions, while for the rest of variables, the percentage is approximately equal $(38,26 \%-39,13 \%)$. The empirical findings are presented in Table 14.

Table 14. Statistical characteristics of the variables regarding the enforcing of the administrative rules

\begin{tabular}{|c|c|c|c|c|c|c|}
\hline Characteristics & \multirow[t]{2}{*}{$\mathbf{N}$} & \multirow[t]{2}{*}{ Mean } & \multirow[t]{2}{*}{ Variance } & \multirow[t]{2}{*}{ Skewness } & \multirow[t]{2}{*}{ Kurtosis } & \multirow[t]{2}{*}{ Sum } \\
\hline Variables & & & & & & \\
\hline q13a & 575 & 0.4835 & 0.250 & 0.066 & -2.003 & 278 \\
\hline$q 13 b$ & 575 & 0.3826 & 0.237 & 0.484 & -1.772 & 220 \\
\hline$q 13 c$ & 575 & 0.3861 & 0.237 & 0.469 & -1.786 & 222 \\
\hline$q 13 d$ & 575 & 0.3913 & 0.239 & 0.447 & -1.807 & 225 \\
\hline
\end{tabular}

The simultaneous appearance of several types of causes that affect the application of administrative rules may be pointed by analyzing the sum dependent variable (Table 15). If we eliminate the lack of options for one of the four variables, we find that $48,5 \%$ of the answers opt for the simultaneity of several causes of the ill enforcement of administrative rule.

Table 15. Cumulative frequencies of the variables on enforcing the administrative rules

\begin{tabular}{|l|l|l|l|l|}
\hline $\mathbf{q 1 3 a + q 1 3 b + q 1 3 c + q 1 3 d}$ & Frequency & Percent & Valid Percent & $\begin{array}{l}\text { Cumulative } \\
\text { Percent }\end{array}$ \\
\hline 0.00 & 38 & 6.6 & 6.6 & 6.6 \\
\hline 1.00 & 282 & 49.0 & 49.0 & 55.7 \\
\hline
\end{tabular}




\begin{tabular}{|l|l|l|l|l|}
\hline 2.00 & 149 & 25.9 & 25.9 & 81.6 \\
\hline 3.00 & 59 & 10.3 & 10.3 & 91.8 \\
\hline 4.00 & 47 & 8.2 & 8.2 & 100 \\
\hline
\end{tabular}

An analysis of the correlations between the variables suggests a weak correlation $(-0.080-0.123)$. The correlations are significant at the 0.01 level and only between q13d and q13a $(0.123)$ or q13c $(0.118)$.

The behavior the four independent variables exhibit gives us the possibility of considering a cumulative dependent variable, q13, which should be correlated with the other dependent variables already defined or not. As such, we will consider the following dependent variable:

q13: $\mathrm{N}->[0,5]$.

$q 13=(q 13 a+q 13 b+q 13 c+q 13 d)$

Table 16 offers the characteristics of the variable q13.

Table 16. Characteristics of the aggregate variable regarding the enforcing of the administrative rules

\begin{tabular}{|l|l|l|l|l|l|l|l|l|}
\hline & $\mathbf{N}$ & Mean & Std. & Variance & \multicolumn{2}{|c|}{ Skewness } & \multicolumn{2}{|l|}{ Kurtosis } \\
\cline { 2 - 9 } & Statistic & Statistic & Statistic & Statistic & Statistic & $\begin{array}{l}\text { Std. } \\
\text { error }\end{array}$ & Statistic & $\begin{array}{l}\text { Std. } \\
\text { error }\end{array}$ \\
\hline q13poz & 575 & 1.6435 & 1.02912 & 1.059 & .843 & .102 & .087 & .203 \\
\hline $\begin{array}{l}\text { Valid } \\
\text { (listwise) }\end{array}$ & 575 & & & & & & & \\
\hline
\end{tabular}

From the characteristics presented above and in Figure 5, we conclude that:

- The series of data presents a low homogeneity $(62,7 \%)$, due to a high standard deviation and variance.

- There is a positive Skewness $(S=0,843)$, and a not significant deviation from normality $(K=0,087)$. 
Figure 5. Histogram of series on enforcing the administrative rules

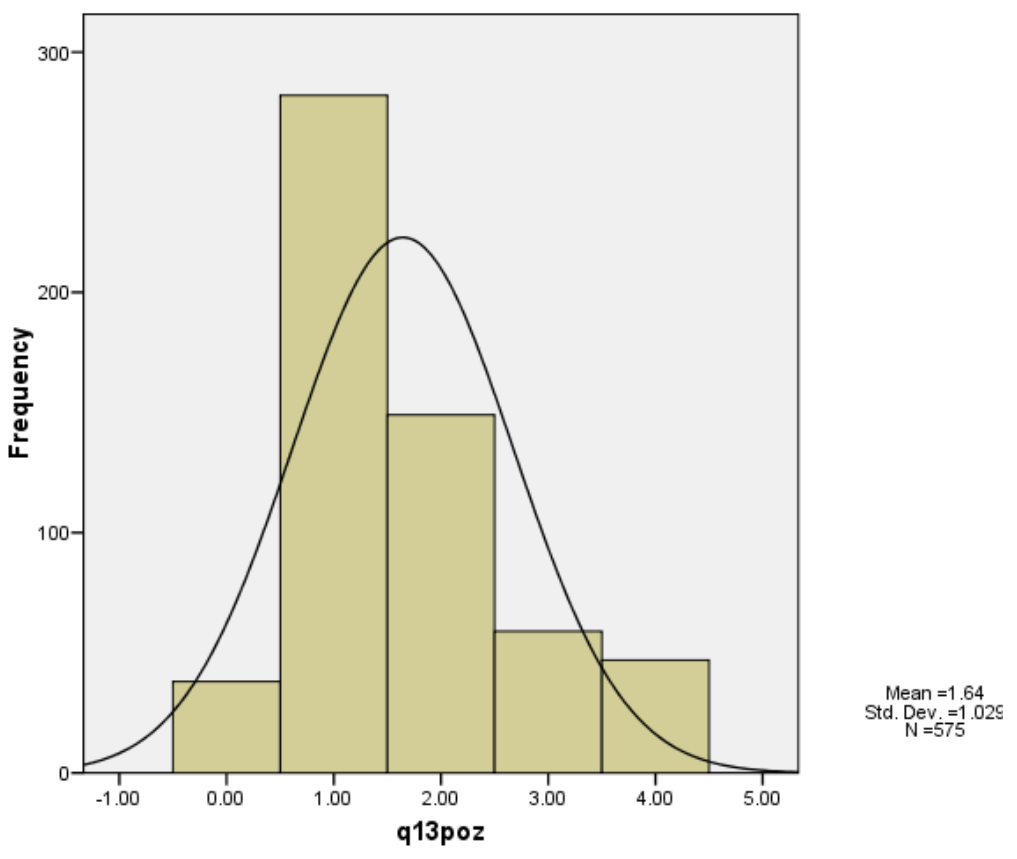

From the viewpoint of our study, an aggregated variable which better expresses the state of art of the public administration system on the internalization of the rule of law should integrate a complementary variable:

q13compl: $\mathrm{N}->[1,5]$

q13compl $=5-q 13$.

The justification of this option comes from a positive approach of the internalization of principles and values the European Administrative Space exhibits. This implies the aggregation of several variables whose values have the same trend - of increasing and downsizing - as the trends of the administrative processes evaluating the variables in question.

d) Improving the legal framework specific to the administrative rules 
Deepening the internalization of the European Administrative Space principles and values in the Romanian public administration needs continuous and diverse legal provisions so as to more properly describe the new realities of the reformed national administration. The actual assessment offers a more opportune perspective on four directions derived from both the strategic reform orientation as well as from the good European practices and the principles of the European Administrative Space.

In this context, the four variables present the stabilization of the normative framework in force $(q 14 a)$, regulation of new administrative realities (q14b), increasing the complexity of the legal provisions (q14c), as well as a better correlation of the legislative provisions ( $q 14 d)$. There was the possibility of multiple answers, and a analysis of the results gave us the certitude of the need to approach the process described by the four variables in a more complex manner. The analysis of the statistical characteristics of the four variables shows a high ratio $(60,5 \%)$ of the options regarding the better correlation of the legal provisions, followed by the stabilization of the legal framework $(46,1 \%)$.

Table 17 comprises the empirical results of the analysis we performed.

Table 17. Statistical characteristics of the variables regarding the directions for improving the legislative framework of the public administration

\begin{tabular}{|c|c|c|c|c|c|c|}
\hline Characteristics & \multirow[t]{2}{*}{$\mathbf{N}$} & \multirow[t]{2}{*}{ Mean } & \multirow[t]{2}{*}{ Variance } & \multirow[t]{2}{*}{ Skewness } & \multirow[t]{2}{*}{ Kurtosis } & \multirow[t]{2}{*}{ Sum } \\
\hline Variables & & & & & & \\
\hline q14a & 575 & 0.4609 & 0.249 & 0.157 & -1.982 & 265 \\
\hline$q 14 b$ & 575 & 0.3426 & 0.226 & 0.665 & -1.563 & 197 \\
\hline q14c & 575 & 0.0957 & 0.087 & 2.757 & 5.619 & 55 \\
\hline $\mathrm{q14d}$ & 575 & 0.6052 & 0.239 & -0.432 & -1.820 & 348 \\
\hline
\end{tabular}

Going back to the idea of systemic effects arising from the complexity of the process under scrutiny, we will find an empirical support of those results coming from the analysis of the sum dependent variable. The data in Table 18 lead us to 
the conclusion that $44,7 \%$ of the answers opt for the simultaneity of $2-4$ administrative actions.

Table 18. Cumulative frequencies of the variables regarding the directions for improving the legislative framework of the public administration

\begin{tabular}{|l|l|l|l|l|}
\hline q14a+q14b+q14c+q14d & Frequency & Percent & Valid Percent & $\begin{array}{l}\text { Cumulative } \\
\text { Percent }\end{array}$ \\
\hline 0.00 & 37 & 6.4 & 6.4 & 6.4 \\
\hline 1.00 & 281 & 48.9 & 48.9 & 55.3 \\
\hline 2.00 & 196 & 34.1 & 34.1 & 89.4 \\
\hline 3.00 & 52 & 9.0 & 9.0 & 98.4 \\
\hline 4.00 & 9 & 1.6 & 1.6 & 100.0 \\
\hline
\end{tabular}

The four variables are relatively independent, Pearson correlation coefficients being settled between 0,002 (between q14c and q14b), 0,033 (between q14a and $q 14 d$ ), respectively $-0,190$ (between $q 14 a$ and $q 14 b$ ). A significant negative correlation at the 0,01 level appears between $q 14 a$ and $q 14 b$, and at the 0,05 level, between q14b and q14d $(-0,107)$.

In this context, just in the case of previous variables, we note the necessity of constructing a cumulative dependent variable, q14, which should systemically include the directions set forward for the improving of the legal framework of public administration.

We will consider, as such, the variables:

q14 : N $->[0,5]$

$q 14=(q 14 a+q 14 b+q 14 c+q 14 d)^{\star} 5 / 4$

Table 19 offers the characteristics of the variable q14. 
Table 19. Characteristics of the aggregate variable regarding the directions for improving the legislative framework of the public administration

\begin{tabular}{|l|l|l|l|l|l|l|l|}
\hline N & Mean & Std. & Variance & \multicolumn{2}{|c|}{ Skewness } & \multicolumn{2}{c|}{ Kurtosis } \\
\hline Statistic & Statistic & Statistic & Statistic & Statistic & Std. error & Statistic & Std. error \\
\hline 575 & 1.8804 & 1.01134 & 1.023 & .580 & .102 & .390 & .203 \\
\hline 575 & & & & & & & \\
\hline
\end{tabular}

From the characteristics presented above and in Figure 6, we conclude that:

- The series of data presents a lower homogeneity than the previous $(53,77 \%)$.

- There is a positive Skewness $(S=0,580)$, and a not significant deviation from normality $(K=0,390)$.

Figure 6. Histogram of the series of data regarding the directions for improving the legislative framework of the public administration

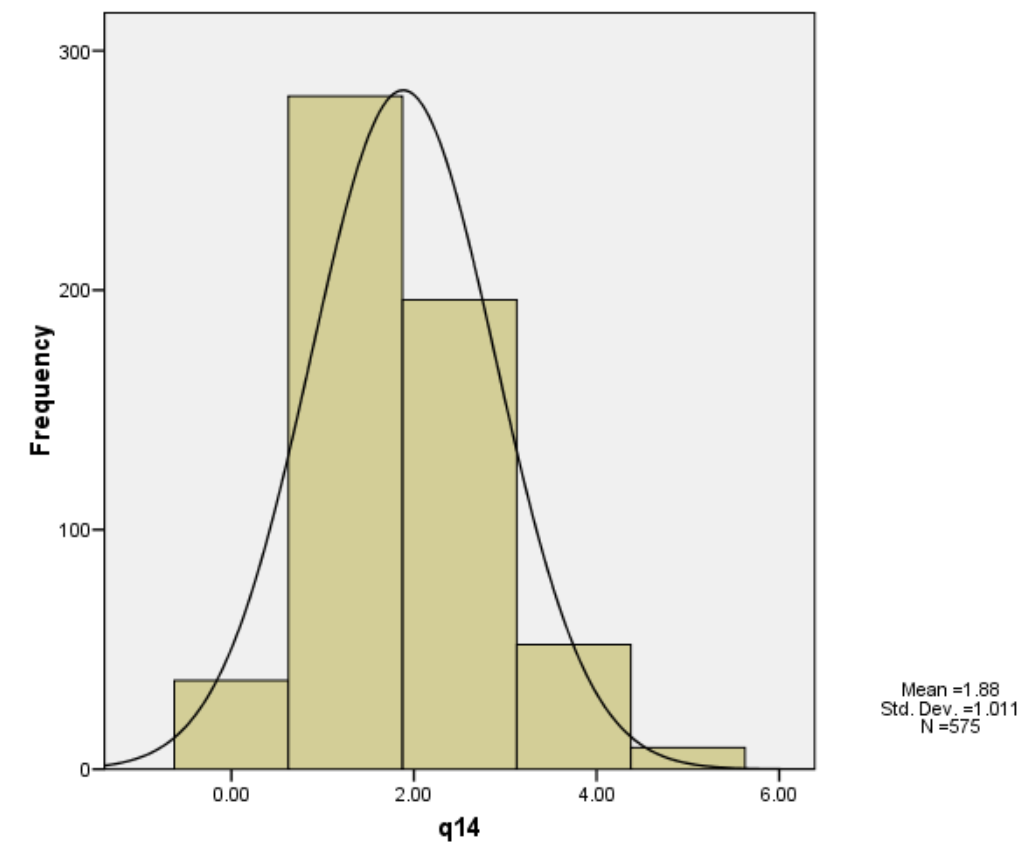




\section{e) Stability of legal framework of the public administration}

The study of different reports on the state of art and the problematic of the Romanian public administration pointed towards some of the most important problems regarding the stability of the legal framework of the public administration. The multitude of legal texts, as well as their frequent amendments determined a serious and disruptive phenomenon which endangers, as will be shown, the internalization of the European Administrative Space principles.

In this context, we considered necessary to introduce several control variables that should evaluate the views inside the system in regard to the stability of a certain legal framework. Using such control variables is to be considered complementary to the already defined variables of the European Administrative Space principles.

Considering that the stability of the legal framework is directly proportional to the number of years of continuous application of the same provisions, the control variable will be:

q15compl: $\mathrm{N}->[1,5]$

q15compl: (4 - q15)*5/3.

The characteristics of the control variable denote, on one hand, the general opinion $(46,8 \%)$ according to which the legal framework is stable after a minimum of 5 years practice. Also, 38,6\% of the answers link the stability to a minimum 10 years practice, while only $14,6 \%$ support the idea of stability as linked to a minimum 1 year of practice. Naturally, considering the type of variables, the one in question is independent in connection to all other aggregated variables, its Pearson correlation coefficients being between -0.042 and 0,032 .

Table 20. Characteristics of the variable regarding the stability of legal framework 


\begin{tabular}{|l|l|l|l|l|l|l|l|}
\hline N & Mean & Std. & Variance & \multicolumn{2}{|c|}{ Skewness } & \multicolumn{2}{c|}{ Kurtosis } \\
\hline Statistic & Statistic & Statistic & Statistic & Statistic & Std. error & Statistic & Std. error \\
\hline 575 & 3.7304 & 1.15646 & 1.337 & -.389 & .102 & -.769 & .203 \\
\hline 575 & & & & & & & \\
\hline
\end{tabular}

Figure 7. Histogram of the series of data regarding the stability of legal framework

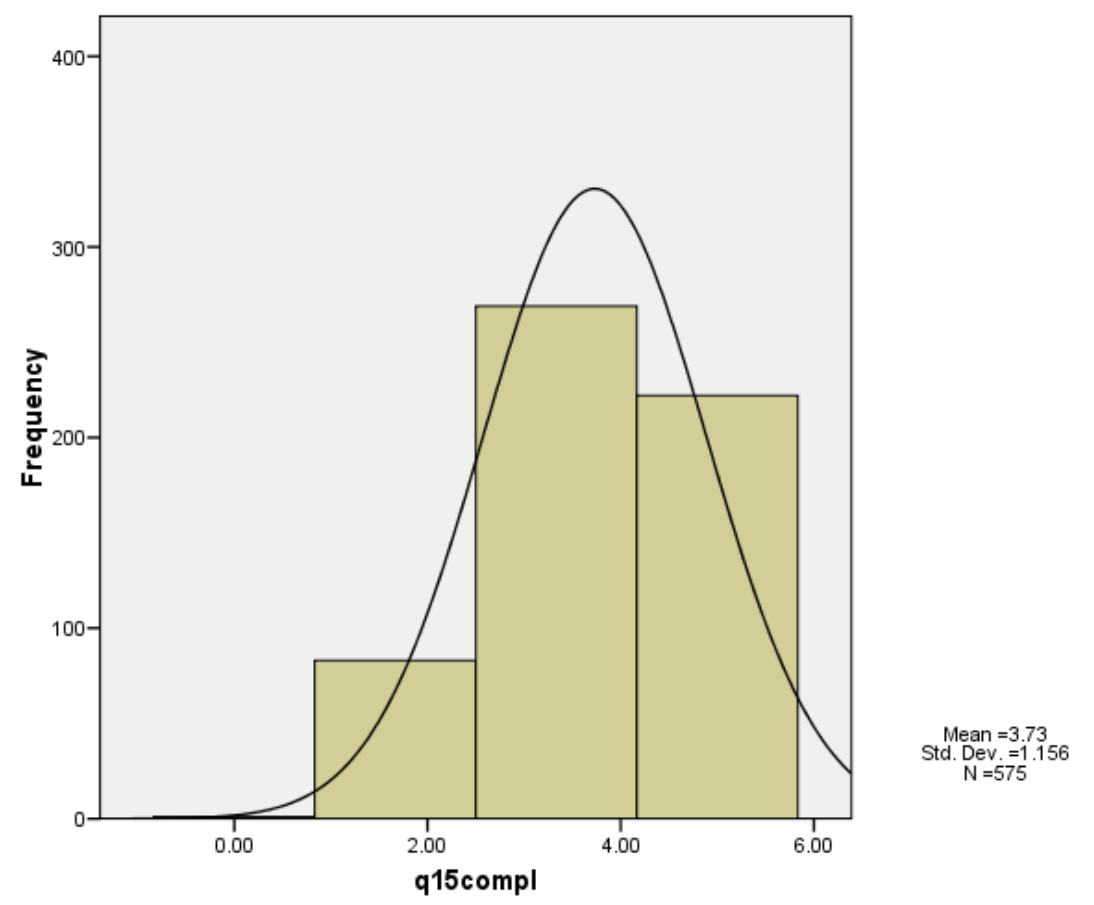

The series of data presents a relatively high homogeneity $(30,1 \%)$, due to the high level of the mean and of standard deviation. Also, the series has a negative Skewness and a not significant deviation from normality.

\section{f) Partial conclusions (1)}

These conclusions aim to make a quantitative assessment of the internalization of the principles and values of the European Administrative Space in the Romanian public administration. These principles referred to the rule of law. To approach this, we define a dependent aggregated variable (q1) of level 3 , as a 
weighted average of the four variables of level 2 which we have already analyzed (q11-pond, q12, q13compl, q14).

The bivariate statistical correlations between the four variables are presented in Table 21.

Table 21. Statistical correlation between the variables which describe the rule of law

\begin{tabular}{|c|c|c|c|c|c|}
\hline & & SusLeg & $q 12$ & q13compl & q14 \\
\hline \multirow[t]{3}{*}{ SusLeg } & $\begin{array}{c}\text { Pearson } \\
\text { Correlation }\end{array}$ & 1 & $.293^{* *}$ & $-.224^{\star \star}$ & .274 \\
\hline & $\begin{array}{l}\text { Sig. (2- } \\
\text { tailed) }\end{array}$ & & .000 & .000 & .000 \\
\hline & $\mathrm{N}$ & 575 & 575 & 575 & 575 \\
\hline \multirow[t]{3}{*}{ q12 } & $\begin{array}{c}\text { Pearson } \\
\text { Correlation }\end{array}$ & $.293^{* *}$ & 1 & $-.400^{\star *}$ & $.397^{\star *}$ \\
\hline & $\begin{array}{l}\text { Sig. (2- } \\
\text { tailed) }\end{array}$ & .000 & & .000 & .000 \\
\hline & $\mathrm{N}$ & 575 & 575 & 575 & 575 \\
\hline \multirow[t]{3}{*}{ q13compl } & $\begin{array}{c}\text { Pearson } \\
\text { Correlation }\end{array}$ & $-.224^{* *}$ & $-.400^{* *}$ & 1 & $-.547^{* *}$ \\
\hline & $\begin{array}{l}\text { Sig. (2- } \\
\text { tailed) }\end{array}$ & .000 & .000 & & .000 \\
\hline & $\mathrm{N}$ & 575 & 575 & 575 & 575 \\
\hline \multirow[t]{3}{*}{ q14 } & $\begin{array}{c}\text { Pearson } \\
\text { Correlation }\end{array}$ & $.274^{\star \star}$ & $.397^{\star *}$ & $-.547^{\star \star}$ & 1 \\
\hline & $\begin{array}{l}\text { Sig. (2- } \\
\text { tailed) }\end{array}$ & .000 & .000 & .000 & \\
\hline & $\mathrm{N}$ & 575 & 575 & 575 & 575 \\
\hline
\end{tabular}

${ }^{* *}$ Correlation is significant at the 0.01 level (2-tailed).

It is worth noting that all correlations are significant for 0.01 level. Also, between q11 (SusLeg), q12 and q14 the correlations are positive, and for q13compl they are negative. All these correlations are of below mean intensity.

The aggregated variable of level 3, q1, will be defined as:

q1: $N$-> $[1,5]$

$\mathrm{q} 1=\left(\mathrm{q} 11 \_\right.$pond $\left.+\mathrm{q} 12+\mathrm{q} 13 \mathrm{compl}+\mathrm{q} 14\right) / 4$. 
Its characteristics are presented in Table 22.

Table 22. Statistical characteristics of the aggregate variable regarding the rule of law

\begin{tabular}{|l|l|l|l|l|l|l|l|l|}
\hline & $\mathbf{N}$ & Mean & Std. & Variance & \multicolumn{2}{c|}{ Skewness } & \multicolumn{2}{c|}{ Kurtosis } \\
\cline { 2 - 9 } & Statistic & Statistic & Statistic & Statistic & Statistic & Statistic & Statistic & Std. error \\
\hline $\mathrm{q} 1$ & 575 & 2.4706 & .52186 & .272 & .536 & .272 & -.094 & .203 \\
\hline $\begin{array}{l}\text { Valid N } \\
\text { (listwise) }\end{array}$ & 575 & & & & & & & \\
\hline
\end{tabular}

Statistically speaking, the new series that corresponds to the $q 1$ variable is characterized by a higher homogeneity $(21 \%)$ and a mean closer to the sum $(2,4706)$. Also, we can observe a positive Skewness and a not significant deviation from normality (see Figure 8).

Figure 8. Histogram of the series of data regarding the rule of law

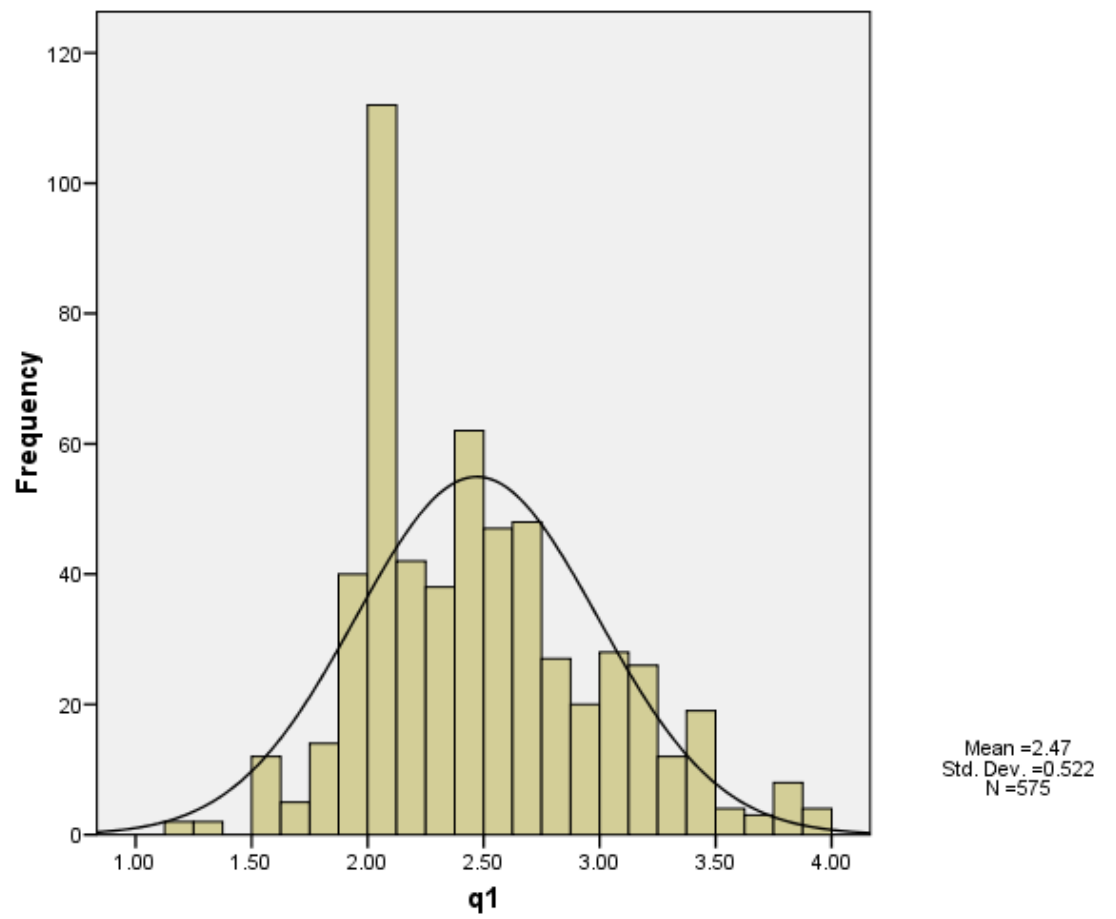


Regarding the internalization process of the principles and values of the European Administrative Space, one may conclude, in a first instance, the following:

- the research shows a medium internalization ( $m=2,47)$;

- the majority distribution of the answers is found around the mean, with a deviation of 0,521 , which means almost $21 \%$.

- The homogeneity jumps that are included in the mean standard deviation are due to the answers that favor the instability, confusion, simplicity and incompleteness of the legal framework. To this we add the answers describing the necessity to aggregate more complex measures for the strengthening and improvement of the legal framework.

To obtain further data may be achieved by means of the analysis of several relevant regressions for the relevant components of the q1 variable. One of these regressions offers us a linear estimation for the SusLeg variable, which attempts to evaluate the legal sustainability of the legal framework and procedures specific to public administration.

Table 23. Statistic coefficients and characteristics for the variables regarding the legal sustainability (case 1)

\begin{tabular}{|c|c|c|c|c|c|c|}
\hline \multirow[t]{2}{*}{ Model } & & \multicolumn{2}{|c|}{$\begin{array}{l}\text { Unstandardized } \\
\text { coefficients }\end{array}$} & $\begin{array}{l}\text { Standardized } \\
\text { Coefficients }\end{array}$ & $t$ & Sig. \\
\hline & & B & Std. error & Beta & & \\
\hline \multirow[t]{4}{*}{1} & (Constant) & 1.876 & .199 & & 9.407 & .000 \\
\hline & q12 & .171 & .036 & .208 & 4.718 & .000 \\
\hline & q13compl & -.041 & .038 & -.052 & -1.074 & .283 \\
\hline & q14 & .165 & .049 & .163 & 3.370 & .001 \\
\hline
\end{tabular}

\begin{tabular}{|l|l|r|r|r|r|}
\hline \multirow{3}{*}{ Model } & \multirow{2}{*}{$95 \%$ Confidence interval for B } & \multicolumn{2}{|c|}{ Collinearity Statistics } \\
\cline { 3 - 6 } & & Lower Bound & Upper Bound & Tolerance & VIF \\
\cline { 2 - 6 } & (Constant) & 1.485 & 2.268 & & \\
\hline
\end{tabular}




\begin{tabular}{|l|l|r|r|r|r|}
\hline $\mathbf{1}$ & q12 & .100 & .242 & .795 & 1.258 \\
\cline { 2 - 6 } & q13compl & -.117 & .034 & .661 & 1.513 \\
\cline { 2 - 6 } & q14 & .069 & .261 & .663 & 1.508 \\
\hline
\end{tabular}

Using the data from Table 23 we find a linear relation according to which:

SusLeg $=1,876+0,171 q 12-0,041$ q13compl $+0,165 q 14$

The levels of trust and tolerance regarding the statistic collinearity are connected in offering an image of the influence each function has on the legal sustainability. It is very interesting that the influence of the variables q12 and q14 are based on a direct proportionality. This comes as different from the influence of q13compl where the proportionality is indirect. In connection to the other variables, we observe that its influence is low, given the regression coefficient $(-0,041)$ and the high standard error $(0,038)$. In this context, we may consider the situation in which the regression for SusLeg ignores the q13compl variable.

Table 24. Statistic coefficients and characteristics for the variables regarding the legal sustainability (case 2)

\begin{tabular}{|c|c|c|c|c|c|c|}
\hline \multirow{2}{*}{\multicolumn{2}{|c|}{ Model }} & \multicolumn{2}{|c|}{$\begin{array}{c}\text { Unstandardized } \\
\text { Coefficients }\end{array}$} & \multirow{2}{*}{$\begin{array}{c}\text { Standardized } \\
\text { Coefficients } \\
\text { Beta } \\
\end{array}$} & \multirow[b]{2}{*}{$\mathrm{t}$} & \multirow[b]{2}{*}{ Sig. } \\
\hline & & $B$ & Std. Error & & & \\
\hline \multirow[t]{3}{*}{1} & (Constant) & 1.689 & .096 & & 17.549 & .000 \\
\hline & q12 & .180 & .035 & .219 & 5.121 & .000 \\
\hline & q14 & .189 & .043 & .187 & 4.356 & .000 \\
\hline
\end{tabular}

\begin{tabular}{|c|c|c|c|c|c|}
\hline \multicolumn{2}{|c|}{ Model } & \multicolumn{2}{|c|}{$\begin{array}{c}\text { 95\% Confidence Interval for } \\
\text { B }\end{array}$} & \multicolumn{2}{|c|}{ Collinearity Statistics } \\
\hline & & Lower Bound & $\begin{array}{l}\text { Upper } \\
\text { Bound }\end{array}$ & Tolerance & VIF \\
\hline \multirow[t]{3}{*}{1} & (Constant) & 1.500 & 1.878 & & \\
\hline & q12 & .111 & .249 & .843 & 1.187 \\
\hline & q14 & .104 & .274 & .843 & 1.187 \\
\hline
\end{tabular}


In this second case, one observes an increase of the impact the variables q12, regarding the elimination of the deficiencies and q14 regarding the improvement of legal framework have on the sustainability of legal framework. In the same time, the constant part is decreasing concomitant with the reduction of nearly $50 \%$ of the standard error. This leads us to the conclusion that the influence of other factors on the legal sustainability is lower.

\subsubsection{Openness towards the citizen}

The evaluation of the openness towards citizens of the public administration is based on four aggregated variables of level 2, which in accordance to the principles of the European Administrative Space and their content take into consideration: firstly, the internal assessment, from a national and European perspective, of the level of multiplication and implementation of the situations in which administration works for the citizen, does not discriminate them and treats them equally. Secondly, the degrees of multiplication and implementation of the non-discriminatory attitudes (towards religion, ethnicity, gender, sex, disabilities), as well as different other important characteristics of the public administration regarding the institutional transparency, the procedural simplification and equity, the efficiency, the dynamism and coherence of the actions, the decisional objectivity and the political independence.

a) Characteristics of the relation between the national public administration with the citizen

The three independent variables, q21a - Romanian public administration in the citizens' service, q21b - Romanian citizens are non-discriminated and q21c Romanian citizens are equal before the law have been evaluated in a scale from 1 to 5 . in order to ensure the compatibility of evaluation with the objectives of the present study, we have considered true the assumption that the process of internalization of the analyzed principle has the same trend as the existence of the other three characteristics. In this context, for the aggregated dependent 
variable, q21, we will use several complementary independent variables, $q 21 x \_c o m p l=6-q 21 x, x=a, b, c$.

The statistical characteristics of the three variables are presented in Table 25 while the Pearson correlations of the four variables are presented in Table 26.

Table 25. Statistical characteristics of the independent variables describing the relation between the Romanian administration and the citizen

\begin{tabular}{|l|r|r|r|r|r|r|r|r|}
\hline & $\mathrm{N}$ & Mean & $\begin{array}{c}\text { Std. } \\
\text { Deviation }\end{array}$ & Variance & \multicolumn{2}{c|}{ Skewness } & \multicolumn{2}{c|}{ Kurtosis } \\
\hline & Statistic & Statistic & Statistic & Statistic & Statistic & Std. Error & Statistic & Std. Error \\
\hline q21a_compl & 575 & 3.2330 & 1.27750 & 1.632 & -.176 & .102 & -.934 & .203 \\
q21b_compl & 575 & 2.8070 & 1.31698 & 1.734 & .052 & .102 & -1.137 & .203 \\
q21c_compl & 575 & 2.9496 & 1.41885 & 2.013 & .122 & .102 & -1.289 & .203 \\
Valid N & 575 & & & & & & & \\
(listwise) & & & & & & \\
\hline
\end{tabular}

Table 26. Statistical correlations of the independent variables describing the relation between the Romanian administration and the citizen

\begin{tabular}{|c|c|c|c|c|}
\hline & & q21a_compl & q21b_compl & q21c_compl \\
\hline \multirow[t]{3}{*}{ q21a_compl } & $\begin{array}{l}\text { Pearson } \\
\text { Correlation }\end{array}$ & 1 & $.338\left({ }^{* *}\right)$ & $.328\left({ }^{* *}\right)$ \\
\hline & Sig. (2-tailed) & & .000 & .000 \\
\hline & $\mathrm{N}$ & 575 & 575 & 575 \\
\hline \multirow[t]{3}{*}{ q21b_compl } & $\begin{array}{l}\text { Pearson } \\
\text { Correlation }\end{array}$ & $.338\left({ }^{* *}\right)$ & 1 & $.416\left({ }^{* *}\right)$ \\
\hline & Sig. (2-tailed) & .000 & & .000 \\
\hline & $\mathrm{N}$ & 575 & 575 & 575 \\
\hline \multirow[t]{3}{*}{ q21c_compl } & $\begin{array}{l}\text { Pearson } \\
\text { Correlation }\end{array}$ & $.328\left({ }^{* *}\right)$ & $.416\left({ }^{* *}\right)$ & 1 \\
\hline & Sig. (2-tailed) & .000 & .000 & \\
\hline & $\mathrm{N}$ & 575 & 575 & 575 \\
\hline
\end{tabular}

Correlation is significant at the 0.01 level (2-tailed).

One may observe that all correlations are positive and significant relevant for 0.01 level and below mean intensity. The dependent aggregated variable of level 2, q21 will be built as a weighted average of the three independent variables. The 
coefficients for the weightiness are determined with the help of the correlation coefficients as normalized. We will thus obtain:

q21: $\mathrm{N}->[1,5]$

$q 21=0,308$ * q21a_compl + 0,348 * q21b_compl + 0,344 * q21c_compl.

The statistical characteristics of the variable q21 are presented in Table 27.

Table 27. Statistical characteristics of the aggregated variable q21.

\begin{tabular}{|l|r|r|c|c|r|r|r|r|}
\hline & $\mathrm{N}$ & Mean & $\begin{array}{c}\text { Std. } \\
\text { Deviation }\end{array}$ & Variance & \multicolumn{2}{|c|}{ Skewness } & \multicolumn{2}{c|}{ Kurtosis } \\
\hline & Statistic & Statistic & Statistic & Statistic & Statistic & Std. Error & Statistic & Std. Error \\
\hline q21 & 575 & 2.9872 & 1.01859 & 1.038 & -.051 & .102 & -.575 & .203 \\
$\begin{array}{l}\text { Valid N } \\
\text { (listwise) }\end{array}$ & 575 & & & & & & & \\
\hline
\end{tabular}

The series of data we obtained by aggregating the independent variables presented above is a homogenous series (34\%), almost symmetrical, with a slight left curve and a significant deviation (see Figure 9).

Figure 9. Histogram of the series of data regarding the relation between the Romanian administration and the citizen

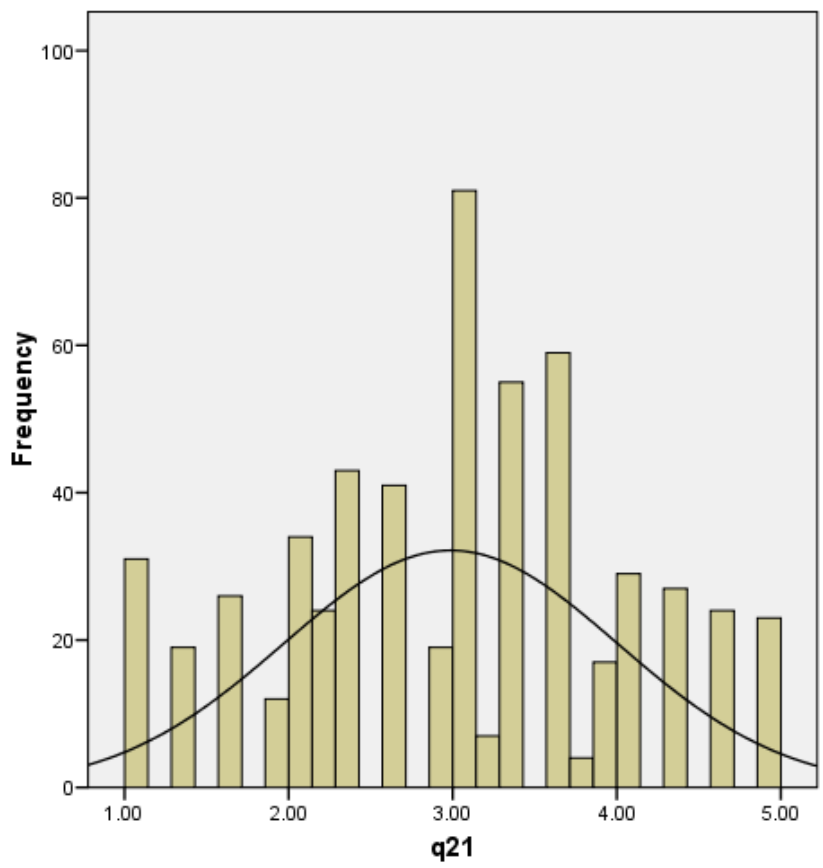


b) Characteristics of the European public administration in relation to the citizen

From similar considerations with those presented in the previous sub section (a), we will take into consideration the independent variables $q 22 x \_c o m p l=6-q 22 x$, $x=a, b, c$.

The statistical characteristics of the three independent variables are presented in Table 28, and the statistical correlations are described in Table 29.

Table 28. Statistical characteristics of the independent variables regarding the relation between the European administration and the citizen

\begin{tabular}{|l|r|r|c|r|r|r|r|r|}
\hline & $\mathrm{N}$ & Mean & $\begin{array}{c}\text { Std. } \\
\text { Deviation }\end{array}$ & \multicolumn{1}{c|}{ Variance } & \multicolumn{2}{|c|}{ Skewness } & \multicolumn{2}{|c|}{ Kurtosis } \\
\hline & Statistic & \multicolumn{1}{c|}{ Statistic } & \multicolumn{1}{c|}{ Statistic } & \multicolumn{1}{c|}{ Statistic } & \multicolumn{1}{|c|}{ Statistic } & Std. Error & Statistic & Std. Error \\
\hline q22a_compl & 575 & 3.6643 & 1.57740 & 2.488 & -.876 & .102 & -.872 & .203 \\
q22b_compl & 575 & 3.1009 & 1.62201 & 2.631 & -.260 & .102 & -1.584 & .203 \\
q22c_compl & 575 & 3.4243 & 1.64246 & 2.698 & -.588 & .102 & -1.343 & .203 \\
Valid N & 575 & & & & & & & \\
(listwise) & & & & & & & \\
\hline
\end{tabular}

Table 29. Statistical correlations of the independent variables regarding the relation between the European administration and the citizen

\begin{tabular}{|rl|r|r|r|}
\hline & & q22a_compl & q22b_compl & q22c_compl \\
\hline q22a_compl & Pearson & 1 & $.589\left(^{* *}\right)$ & $.510\left(^{* *}\right)$ \\
& Correlation & & .000 & .000 \\
& Sig. (2-tailed) & 575 & 575 & 575 \\
& N & $.589\left(^{* *}\right)$ & 1 & $.663\left(^{* *}\right)$ \\
q22b_compl & Pearson & .000 & & .000 \\
& Correlation & 575 & 575 & 575 \\
& Sig. (2-tailed) & $.510\left(^{* *}\right)$ & $.663\left(^{* *}\right)$ & 1 \\
& N & .000 & .000 & \\
q22c_compl & Pearson & 575 & 575 & 575 \\
& Correlation & Sig. (2-tailed) & & \\
& N & &
\end{tabular}

** Correlation is significant at the 0.01 level (2-tailed). 
Just as in the previous chapter, the correlations are significant for 0.01 level, positive and situated above the mean. In this context, we will consider the aggregated variable q22 as a weighted average between the three variables analyzed above. Their weightiness coefficients will be determined in the same way as before.

We will obtain:

q22: $\mathrm{N}->[1,5]$

$\mathrm{q} 22=0,312{ }^{*} \mathrm{q} 22 \mathrm{a} \_\mathrm{compl}+0,355{ }^{*} \mathrm{q} 22 \mathrm{~b} \_\mathrm{compl}+0,333^{*} \mathrm{q} 22 \mathrm{c} \_\mathrm{compl}$.

The statistical characteristics of the variable q22 are presented in Table 30.

Table 30. Statistical characteristics of the aggregated variable q22

\begin{tabular}{|l|r|r|c|c|r|r|r|r|}
\hline & $\mathrm{N}$ & Mean & $\begin{array}{c}\text { Std. } \\
\text { Deviation }\end{array}$ & Variance & \multicolumn{2}{|c|}{ Skewness } & \multicolumn{2}{|c|}{ Kurtosis } \\
\hline & Statistic & Statistic & Statistic & Statistic & Statistic & Std. Error & Statistic & Std. Error \\
\hline q22 & 575 & 3.3844 & 1.37779 & 1.898 & -.533 & .102 & -1.068 & .203 \\
Valid N \\
(listwise)
\end{tabular}

For the new variable, the average is higher and the not-homogeneity is also high $(41 \%)$. Just as other independent variables, the aggregate variable presents an important negative distortion due to the high weightiness of the "not-answers" (see Figure 10). 
Figure 10. Histogram of the series of data regarding the relation between the European administration and the citizen

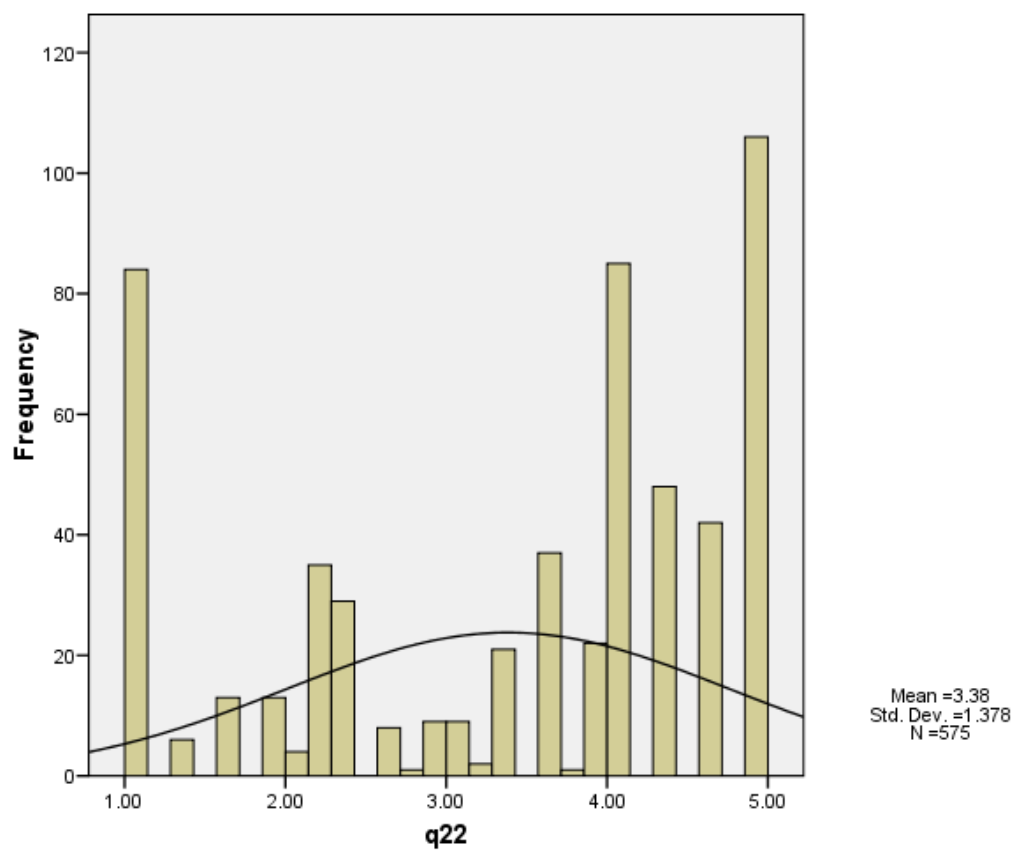

c) Non-discrimination in relation between the Romanian public administration and the citizen

The questionnaire analyzes the perception on the non-discrimination (based on religion, ethnicity, gender, sex and disabilities) of the citizen in relation to the public administration. Just in the last two cases described in the subsections above, the used variables will be $q 23 x \_c o m p l=6-q 23 x, x=a, b, c, d, e$.

Table 31. Statistical characteristics of the independent variables regarding the non-discrimination in the relation of the Romanian public administration with the citizen

\begin{tabular}{|l|r|r|r|r|r|r|r|r|}
\hline & $\mathrm{N}$ & Mean & $\begin{array}{c}\text { Std. } \\
\text { Deviation }\end{array}$ & Variance & \multicolumn{2}{|c|}{ Skewness } & \multicolumn{2}{c|}{ Kurtosis } \\
\hline & Statistic & Statistic & Statistic & Statistic & Statistic & Std. Error & Statistic & Std. Error \\
\hline q23a_compl & 575 & 3.4017 & 1.61881 & 2.621 & -.482 & .102 & -1.416 & .203 \\
q23b_compl & 575 & 3.1843 & 1.50056 & 2.252 & -.354 & .102 & -1.335 & .203 \\
q23c_compl & 575 & 3.1461 & 1.59470 & 2.543 & -.271 & .102 & -1.521 & .203
\end{tabular}




\begin{tabular}{|l|l|l|l|l|l|l|l|l|} 
q23d_compl & 575 & 3.1635 & 1.58094 & 2.499 & -.250 & .102 & -1.513 & .203 \\
q23e_compl & 575 & 3.0974 & 1.53391 & 2.353 & -.164 & .102 & -1.460 & .203 \\
Valid N & 575 & & & & & & & \\
(listwise) & & & & & & & \\
\hline
\end{tabular}

The brief analysis of the empirical data from Table 31 shows a uniform perception, above the average, on the aspects that deal with the nondiscrimination in its multiple forms. The series of data we obtained are nothomogenous, with a level of non-homogeneity situated between $47 \%$ and $51 \%$. All variables present a negative distortion due, in principle, to the high number of "not answers".

Table 32. Pearson correlations for the independent variables regarding the nondiscrimination in the relation of the Romanian public administration with the citizen

\begin{tabular}{|c|c|c|c|c|c|c|}
\hline & & q23a_compl & q23b_compl & q23c_compl & q23d_compl & q23e_compl \\
\hline \multirow[t]{3}{*}{ q23a_compl } & $\begin{array}{l}\text { Pearson } \\
\text { Correlation }\end{array}$ & 1 & $.734\left({ }^{* *}\right)$ & $.690\left({ }^{* *}\right)$ & $.738\left({ }^{* *}\right)$ & $.614\left(^{* *}\right)$ \\
\hline & Sig. (2-tailed) & & .000 & .000 & .000 & .000 \\
\hline & $\mathrm{N}$ & 575 & 575 & 575 & 575 & 575 \\
\hline \multirow[t]{3}{*}{ q23b_compl } & $\begin{array}{l}\text { Pearson } \\
\text { Correlation }\end{array}$ & $.734\left({ }^{* *}\right)$ & 1 & $.734\left({ }^{* *}\right)$ & $.757\left({ }^{* *}\right)$ & $\left..691{ }^{(* *}\right)$ \\
\hline & Sig. (2-tailed) & .000 & & .000 & .000 & .000 \\
\hline & $\mathrm{N}$ & 575 & 575 & 575 & 575 & 575 \\
\hline \multirow[t]{3}{*}{ q23c_compl } & $\begin{array}{l}\text { Pearson } \\
\text { Correlation }\end{array}$ & $.690\left({ }^{* *}\right)$ & $.734\left({ }^{* *}\right)$ & 1 & $.805\left({ }^{* *}\right)$ & $.714\left(^{* *}\right)$ \\
\hline & Sig. (2-tailed) & .000 & .000 & & .000 & .000 \\
\hline & $\mathrm{N}$ & 575 & 575 & 575 & 575 & 575 \\
\hline \multirow[t]{3}{*}{ q23d_compl } & $\begin{array}{l}\text { Pearson } \\
\text { Correlation }\end{array}$ & $.738\left({ }^{* *}\right)$ & $.757\left({ }^{* *}\right)$ & $.805\left({ }^{* *}\right)$ & 1 & $.759\left({ }^{* *}\right)$ \\
\hline & Sig. (2-tailed) & .000 & .000 & .000 & & .000 \\
\hline & $N$ & 575 & 575 & 575 & 575 & 575 \\
\hline \multirow[t]{3}{*}{ q23e_compl } & $\begin{array}{l}\text { Pearson } \\
\text { Correlation }\end{array}$ & $.614\left(^{* *}\right)$ & $\left..6911^{* *}\right)$ & $.714\left({ }^{* *}\right)$ & $.759\left(^{* *}\right)$ & 1 \\
\hline & Sig. (2-tailed) & .000 & .000 & .000 & .000 & \\
\hline & $\mathrm{N}$ & 575 & 575 & 575 & 575 & 575 \\
\hline
\end{tabular}

** Correlation is significant at the 0.01 level (2-tailed).

Worth noticing is that all correlation coefficients are positive and are situated above average (between 0,614 - 0,805), and the correlations are significant for 
0,01 level. Just as in previous situations, we will design a variable on dondiscrimination, $\mathrm{q} 23$, as an weighted average of the analyzed independent variables. As such,

q23: $\mathrm{N}->[1,5]$

$q 23=0,192{ }^{*} \mathrm{q} 23 a \_c o m p l+0,202{ }^{*} \mathrm{q} 23 \mathrm{~b} \_$compl $+0,203{ }^{*} \mathrm{q} 23 \mathrm{c}$ _compl $+0,211$

* q23d_compl + 0,192* q23e_compl.

The statistical characteristics of the variable q23 are presented in Table 33.

Table 33. Statistical characteristics of the aggregated variable regarding the nondiscrimination in the relation of the Romanian public administration with the citizen

\begin{tabular}{|l|r|r|r|r|r|r|r|r|}
\hline & \multicolumn{1}{|c|}{$\mathrm{N}$} & \multicolumn{1}{c|}{ Mean } & Std. Deviation & Variance & \multicolumn{2}{c|}{ Skewness } & \multicolumn{2}{c|}{ Kurtosis } \\
\hline & Statistic & Statistic & Statistic & Statistic & Statistic & Std. Error & Statistic & Std. Error \\
\hline q23 & 575 & 3.1972 & 1.38321 & 1.913 & -.336 & .102 & -1.234 & .203 \\
$\begin{array}{l}\text { Valid N } \\
\text { (listwise) }\end{array}$ & 575 & & & & & & & \\
\hline
\end{tabular}

The series of data we obtained has a high level of homogeneity (43\%), considerably reduced in comparison to that of the independent variables. The series presents a negative distortion due to the high frequency of the "notanswers" (see Figure 11).

Figure 11. Histogram of the series of data regarding the non-discrimination in the relation of the Romanian public administration with the citizen 


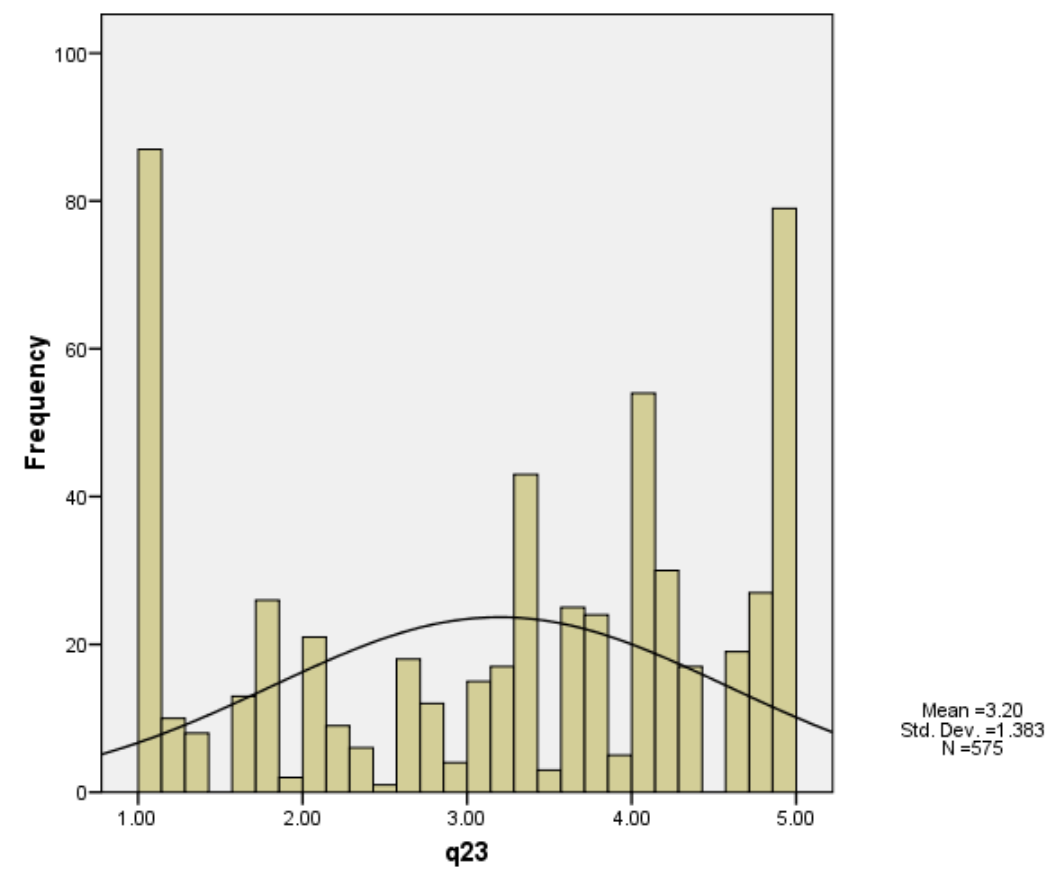

d) Characteristics of an open administration

An open administration is a desideratum of the European Administrative Space and includes, amongst others, the institutional transparency, the simplification, equity and decisional and procedural objectivity, as well as the political independency. These characteristics which are not to be treated exhaustively, have been evaluated by introducing several complementary, binary variables whose aggregation should offer us a proper image on the current state of art in the Romanian public administration.

Taking into account the complementary issue existent between the 16 variables this analysis uses just the first eight. Their statistical characteristics of these variables are presented in Table 34.

Table 34. Statistical characteristics of the independent variables regarding the open administration

\begin{tabular}{|c|c|c|c|}
\hline & $\mathrm{N}$ & Sum & Mean \\
\hline & Statistic & Statistic & Statistic \\
\hline
\end{tabular}




\begin{tabular}{|l|r|r|r|}
\hline Institutional & 575 & 139.00 & .2417 \\
transparency & 575 & 48.00 & .0835 \\
Procedural simplicity & 575 & 94.00 & .1635 \\
Efficiency & 575 & 56.00 & .0974 \\
Organizational & 575 & 53.00 & .0922 \\
dynamism & 575 & 58.00 & .1009 \\
Coherence of actions & 574 & 89.00 & .1551 \\
Procedural equity & 575 & 145.00 & .2522 \\
Decisional objectivity & 574 & & \\
Political independence & & & \\
Valid N (listwise) &
\end{tabular}

\begin{tabular}{|c|r|r|r|r|r|}
\hline $\begin{array}{c}\text { Std. } \\
\text { Deviation }\end{array}$ & Variance & \multicolumn{2}{|c|}{ Skewness } & \multicolumn{2}{|c|}{ Kurtosis } \\
\hline \multicolumn{1}{c|}{ Statistic } & \multicolumn{1}{|c|}{ Statistic } & \multicolumn{1}{c|}{ Statistic } & \multicolumn{1}{|c|}{ Std. Error } & \multicolumn{1}{c|}{ Statistic } & Std. Error \\
\hline .42851 & .184 & 1.210 & .102 & -.539 & .203 \\
.27684 & .077 & 3.020 & .102 & 7.143 & .203 \\
.37012 & .137 & 1.825 & .102 & 1.334 & .203 \\
.29675 & .088 & 2.723 & .102 & 5.433 & .203 \\
.28952 & .084 & 2.827 & .102 & 6.013 & .203 \\
.30142 & .091 & 2.658 & .102 & 5.080 & .203 \\
.36227 & .131 & 1.911 & .102 & 1.658 & .204 \\
.43464 & .189 & 1.144 & .102 & -.693 & .203 \\
& & & & & \\
\hline
\end{tabular}

We observe that the considerably low means of several variables refer to the administrative simplification $(0,0835)$, the organizational dynamics $(0,0975)$ and the coherence of the actions $(0,0922)$. This might lead to more serious analyses on the evolution of the bureaucratic processes in the Romanian public administration. The qualitative conclusions expressed by the media as well as by scholars and practitioners regarding the low efficiency of the Romanian public administration, the lack of institutional transparency and decisional objectivity are confirmed by our data. As such, the aspects we analyzed remain, in perspective, the most important characteristics to influence the general level of internalization of the principles and values of the European Administrative Space. The highest mean $(0,2522)$ we obtained for the political independency may be explained due to the structure of the sample we used, which includes a significant high ratio of high civil servants that are usually the target group for political interventions. An analysis of the Pearson correlation notes positive correlations, of low intensity 
$(0,078-0,412)$ between all the variables in question, except that of political independency, negatively correlated to the rest of variables. (see Table 35).

Table 35. Statistical correlations of independent variables regarding the open administration

\begin{tabular}{|c|c|c|c|c|}
\hline & $\begin{array}{c}\text { Institutional } \\
\text { transparency }\end{array}$ & $\begin{array}{l}\text { Procedural } \\
\text { simplicity }\end{array}$ & Efficiency & $\begin{array}{c}\text { Organizational } \\
\text { dynamism }\end{array}$ \\
\hline $\begin{array}{l}\text { Institutional } \\
\text { transparency }\end{array}$ & 1 & $.211\left(^{* *}\right)$ & $.366\left(^{* *}\right)$ & $.212\left({ }^{* *}\right)$ \\
\hline Procedural simplicity & $.211\left({ }^{* *}\right)$ & 1 & $.207\left(^{* *}\right)$ & $\left..261{ }^{* *}\right)$ \\
\hline Efficiency & $.366\left(^{* *}\right)$ & $.207\left({ }^{* *}\right)$ & 1 & $.283\left({ }^{* *}\right)$ \\
\hline $\begin{array}{l}\text { Organizational } \\
\text { dynamism }\end{array}$ & $.212\left(^{* *}\right)$ & $.261\left(^{* *}\right)$ & $\left..283^{(* *}\right)$ & 1 \\
\hline Coherence of actions & $.213\left({ }^{* *}\right)$ & $.165\left(^{* *}\right)$ & $.412\left({ }^{* *}\right)$ & $.260(* *)$ \\
\hline Procedural equity & $.256\left(^{* *}\right)$ & $.129\left(^{* *}\right)$ & $.227\left(^{* *}\right)$ & $.241\left({ }^{* *}\right)$ \\
\hline Decisional objectivity & $.349\left(^{* *}\right)$ & .078 & $.314\left({ }^{* *}\right)$ & $.278(* *)$ \\
\hline Political independence & $-.216\left(^{* \star}\right)$ & -.059 & $-.138\left(^{* *}\right)$ & -.029 \\
\hline
\end{tabular}

\begin{tabular}{|l|r|r|r|r|}
\hline & $\begin{array}{c}\text { Coherence } \\
\text { of actions }\end{array}$ & $\begin{array}{c}\text { Procedural } \\
\text { equity }\end{array}$ & $\begin{array}{c}\text { Decisional } \\
\text { objectivity }\end{array}$ & \multicolumn{1}{c|}{$\begin{array}{c}\text { Political } \\
\text { independence }\end{array}$} \\
\hline Institutional & $.213\left(^{* *}\right)$ & $.256\left(^{* *}\right)$ & $.349\left(^{* *}\right)$ & $-.216\left(^{* *}\right)$ \\
transparency & $\left..165^{* *}\right)$ & $.129\left(^{* *}\right)$ & .078 & -.059 \\
Procedural simplicity & $.412\left(^{* *}\right)$ & $.227\left(^{* *}\right)$ & $.314\left(^{* *}\right)$ & $-.138\left(^{* *}\right)$ \\
Efficiency & $.260\left(^{* *}\right)$ & $.241\left(^{* *}\right)$ & $.278\left(^{* *}\right)$ & -.029 \\
dynanizational & 1 & $.313\left(^{* *}\right)$ & $.326\left(^{* *}\right)$ & -.019 \\
Coherence of actions & $.313\left(^{* *}\right)$ & 1 & $.364\left(^{* *}\right)$ & -.035 \\
Procedural equity & $.326\left(^{* *}\right)$ & $.364\left(^{* *}\right)$ & 1 & $-.107\left(^{*}\right)$ \\
Decisional objectivity & -.019 & -.035 & $-.107\left(^{*}\right)$ & 1 \\
Political independence & & &
\end{tabular}

** Correlation is significant at the 0.01 level (2-tailed).

* Correlation is significant at the 0.05 level (2-tailed).

In this context, the aggregated variable to be used for the evaluation of the openness of the Romanian public administration will be:

q24: $\mathrm{N}->[1,5]$

$q 24=0,143$ * $q 24 a+0,102 * q 24 b+0,172 * q 24 c+0,115 *$ * $24 d+0,172$ * $q 24 e$

$+0,154{ }^{*} q 24 f+0,164 * q 24 g+0,062 * q 24 h$. 
The coefficients we used in expressing the variable q24 are normalized correlation coefficients, extracted from Table 35.

Table 36. Statistical characteristics of the aggregated variable regarding an open administration

\begin{tabular}{|l|r|r|r|r|r|}
\hline & \multicolumn{1}{|c|}{$\begin{array}{c}\mathrm{N} \\
\text { Statistic }\end{array}$} & $\begin{array}{c}\text { Minimum } \\
\text { Statistic }\end{array}$ & $\begin{array}{c}\text { Maximum } \\
\text { Statistic }\end{array}$ & $\begin{array}{c}\text { Std. } \\
\text { Mean } \\
\text { Statistic }\end{array}$ & $\begin{array}{c}\text { Deviation } \\
\text { Statistic }\end{array}$ \\
\hline q24 & 575 & -.31 & 5.31 & .6386 & 1.13114 \\
$\begin{array}{l}\text { Valid N } \\
\text { (listwise) }\end{array}$ & 575 & & & & \\
\hline
\end{tabular}

\begin{tabular}{|l|r|r|r|r|r|}
\hline & Variance & \multicolumn{2}{|c|}{ Skewness } & \multicolumn{2}{c|}{ Kurtosis } \\
\hline & Statistic & \multicolumn{1}{|c|}{ Statistic } & Std. Error & \multicolumn{1}{c|}{ Statistic } & Std. Error \\
\hline $\begin{array}{l}\text { q24 } \\
\text { Valid N } \\
\text { (listwise) }\end{array}$ & 1.279 & 1.703 & .102 & 2.765 & .203 \\
\hline
\end{tabular}

We observe a not-homogenous emphasis, an asymmetry of the normal curve and a strong positive distortion. Also, we see that the series of data has a significant deviation from normality. (see Figure 12).

Figure 12. Histogram of the series of data regarding an open administration 


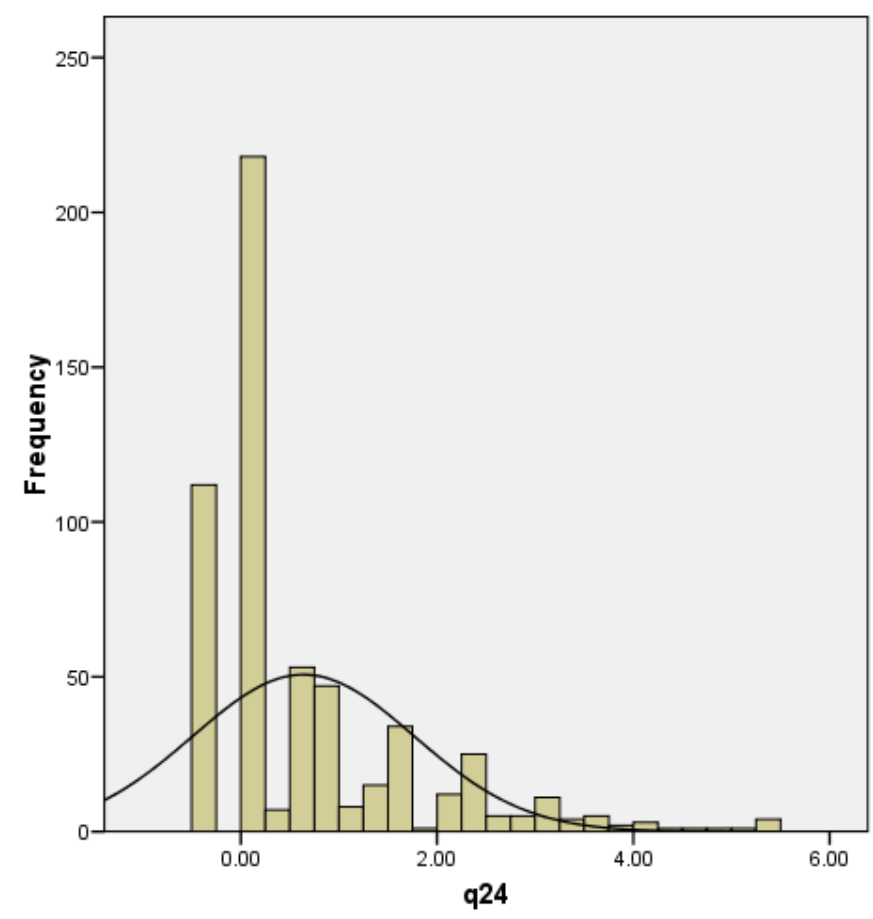

$\begin{aligned} \text { Mean } & =0.64 \\ \text { Std. Dev. } & =1.131\end{aligned}$

e) Partial conclusions (2)

The four aggregated variables offer both an evaluation regarding the level of internalization of the principles and values of the European Administrative Space regarding the openness of the Romanian public administration towards citizens (q21, q23, q24), as well as an image on the way the answer givers see the European administration as a service in the benefit of the citizen (q22). The idea of seeing the national and European public administration as a public service working for the citizens strengthens the latter characteristics regarding the nondiscrimination and equality in connection to the public service.

Amongst the empirical opinions expressed, the two variables - one referring to the Romanian administration (q21) and the other regarding the European administration - are correlated statistical $(0,447)$.

Table 37 presents the Pearson statistical correlation for all aggregated variables analyzed in this sub-section. 
Table 37. Statistical correlations for aggregated variables regarding the openness of the administration towards the citizens

\begin{tabular}{|c|c|c|c|c|c|}
\hline & & q21 & q22 & q23 & q24 \\
\hline \multirow[t]{3}{*}{ q21 } & $\begin{array}{l}\text { Pearson } \\
\text { Correlation }\end{array}$ & 1 & $.447\left({ }^{* *}\right)$ & $.420\left({ }^{* *}\right)$ & $.295\left(^{* *}\right)$ \\
\hline & Sig. (2-tailed) & & .000 & .000 & .000 \\
\hline & $\mathrm{N}$ & 575 & 575 & 575 & 575 \\
\hline \multirow[t]{3}{*}{ q22 } & $\begin{array}{l}\text { Pearson } \\
\text { Correlation }\end{array}$ & $.447\left({ }^{* *}\right)$ & 1 & $.412\left({ }^{* *}\right)$ & $.082\left(^{*}\right)$ \\
\hline & Sig. (2-tailed) & .000 & & .000 & .050 \\
\hline & $\mathrm{N}$ & 575 & 575 & 575 & 575 \\
\hline \multirow[t]{3}{*}{ q23 } & $\begin{array}{l}\text { Pearson } \\
\text { Correlation }\end{array}$ & $.420\left({ }^{* *}\right)$ & $.412\left({ }^{* *}\right)$ & 1 & $.093\left(^{*}\right)$ \\
\hline & Sig. (2-tailed) & .000 & .000 & & .026 \\
\hline & $\mathrm{N}$ & 575 & 575 & 575 & 575 \\
\hline \multirow[t]{3}{*}{ q24 } & $\begin{array}{l}\text { Pearson } \\
\text { Correlation }\end{array}$ & $.295\left({ }^{* *}\right)$ & $.082\left(^{*}\right)$ & $.093\left(^{*}\right)$ & 1 \\
\hline & Sig. (2-tailed) & .000 & .050 & .026 & \\
\hline & $\mathrm{N}$ & 575 & 575 & 575 & 575 \\
\hline
\end{tabular}

Considering all the significant correlations presented in Table 37 in a regression analysis, we will be able to determine both a linear relation between the perception of the Romanian public administration and the European one as a public service, as well as between the first variable and those on nondiscrimination and other characteristics of an open administration.

The latter are described below:

$q 21: 1,869+0,330 * q 22$

$q 21=1,906+0,292 * q 23+0,233 * q 24$

All coefficients of the above regressions are statistically significant. 
The statistical characteristics of the two regressions are presented din Table 38 $(a, b)$

Table 38 a. Statistical characteristics of the regressions regarding the openness of the administration towards citizens

\begin{tabular}{|rl|r|r|r|r|r|}
\hline \multirow{2}{*}{ Model } & \multicolumn{2}{|c|}{$\begin{array}{c}\text { Unstandardized } \\
\text { Coefficients }\end{array}$} & $\begin{array}{c}\text { Standardized } \\
\text { Coefficients }\end{array}$ & $\mathrm{t}$ & Sig. \\
\cline { 2 - 7 } & \multicolumn{1}{|c|}{$\mathrm{B}$} & Std. Error & Beta & $\mathrm{B}$ & Std. Error \\
\hline 1 & (Constant) & 1.869 & .101 & & 18.516 & .000 \\
& $\mathrm{q} 22$ & .330 & .028 & .447 & 11.958 & .000 \\
\hline
\end{tabular}

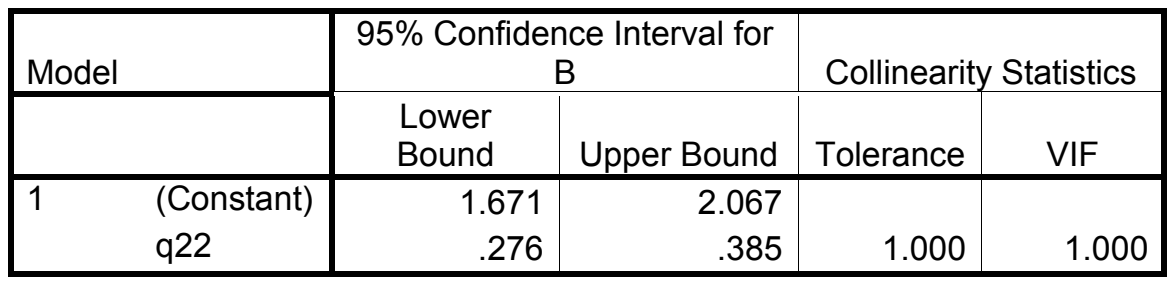

a Dependent Variable: q21

\section{Collinearity Diagnostics(a)}

\begin{tabular}{|rr|r|r|r|r|}
\hline Model Dimension & Eigenvalue & $\begin{array}{c}\text { Condition } \\
\text { Index }\end{array}$ & \multicolumn{2}{|c|}{$\begin{array}{c}\text { Variance } \\
\text { Proportions }\end{array}$} \\
\hline & & (Constant) & \multicolumn{1}{c|}{ q22 } & (Constant) & q22 \\
\hline 1 & 1 & 1.926 & 1.000 & .04 & .04 \\
& 2 & .074 & 5.113 & .96 & .96 \\
\hline
\end{tabular}

a Dependent Variable: q21

Table $38 \mathrm{~b}$. Statistical characteristics of the regressions regarding the openness of the administration towards citizens

\begin{tabular}{|c|c|c|c|c|c|c|}
\hline \multirow{2}{*}{\multicolumn{2}{|c|}{$\begin{array}{l}\text { Mode } \\
\text { I }\end{array}$}} & \multicolumn{2}{|c|}{$\begin{array}{c}\text { Unstandardized } \\
\text { Coefficients }\end{array}$} & \multirow{2}{*}{$\begin{array}{c}\text { Standardized } \\
\text { Coefficients } \\
\text { Beta }\end{array}$} & \multirow[b]{2}{*}{$\mathrm{t}$} & \multirow[b]{2}{*}{ Sig. } \\
\hline & & $\mathrm{B}$ & Std. Error & & & \\
\hline \multirow[t]{3}{*}{1} & (Constant) & 1.906 & .094 & & 20.226 & .000 \\
\hline & q23 & .292 & .027 & .396 & 10.840 & .000 \\
\hline & q24 & .233 & .033 & .259 & 7.075 & .000 \\
\hline
\end{tabular}




\begin{tabular}{|c|c|c|c|c|c|}
\hline \multirow{2}{*}{\multicolumn{2}{|c|}{ Model }} & \multicolumn{2}{|c|}{$\begin{array}{c}\text { 95\% Confidence Interval for } \\
\text { B }\end{array}$} & \multicolumn{2}{|c|}{ Collinearity Statistics } \\
\hline & & Lower Bound & $\begin{array}{l}\text { Upper } \\
\text { Bound }\end{array}$ & Tolerance & VIF \\
\hline \multirow[t]{3}{*}{1} & (Constant) & 1.721 & 2.091 & & \\
\hline & q23 & .239 & .345 & .991 & 1.009 \\
\hline & q24 & .168 & .297 & .991 & 1.009 \\
\hline
\end{tabular}

a Dependent Variable: q21

Collinearity Diagnostics(a)

\begin{tabular}{|c|c|c|c|c|c|c|}
\hline \multirow[t]{2}{*}{ Model } & \multirow[t]{2}{*}{ Dimension } & \multirow{2}{*}{$\begin{array}{l}\text { Eigenvalue } \\
\text { (Constant) }\end{array}$} & \multirow{2}{*}{$\begin{array}{c}\begin{array}{c}\text { Condition } \\
\text { Index }\end{array} \\
\text { q23 } \\
\end{array}$} & \multicolumn{3}{|c|}{ Variance Proportions } \\
\hline & & & & q24 & (Constant) & q23 \\
\hline \multirow[t]{3}{*}{1} & 1 & 2.288 & 1.000 & .03 & .03 & .07 \\
\hline & 2 & .630 & 1.905 & .03 & .03 & .93 \\
\hline & 3 & .082 & 5.281 & .95 & .94 & .00 \\
\hline
\end{tabular}

a Dependent Variable: q21

The description of the cumulative effects of the variables we analyzed will be achieved by the introduction of an aggregated variable of level 3 :

q2: $\mathrm{N}->[1,5]$

$q 2=(q 21+q 23+q 24) / 3$

This variable has the characteristics presented in Table 39. Given the correlations of different intensity, existent between the variables, the latter may be viewed as an weighted variable:

q2_pond $=0,442 * q 21+0,317 * q 13+0,241 * q 14$.

Naturally, the two variables are strongly correlated $(0,990)$. The correlation coefficient is significant for 0,01 level.

Table 39. Characteristics of the aggregated variables regarding the openness of the administration towards citizens 


\begin{tabular}{|l|r|r|r|r|r|r|}
\hline & \multicolumn{1}{|c|}{$\mathrm{N}$} & Minimum & Maximum & Sum & Mean & $\begin{array}{c}\text { Std. } \\
\text { Deviation } \\
\text { Statistic }\end{array}$ \\
\hline Static & Statistic & Statistic & Statistic & Statistic & \multicolumn{1}{c|}{ Static } \\
\hline q2_pond & 575 & .67 & 5.10 & 1307.75 & 2.2744 & .84225 \\
Valid N & 575 & .76 & 5.07 & 1430.48 & 2.4878 & .85427 \\
(listwise) & 575 & & & & & \\
\hline
\end{tabular}

\begin{tabular}{|r|r|r|r|r|}
\hline Variance & \multicolumn{2}{|c|}{ Skewness } & \multicolumn{2}{c|}{ Kurtosis } \\
\hline Statistic & \multicolumn{1}{c|}{ Statistic } & Std. Error & \multicolumn{1}{c|}{ Statistic } & Std. Error \\
\hline .709 & .164 & .102 & -.272 & .203 \\
.730 & -.059 & .102 & -.417 & .203 \\
& & & & \\
\hline
\end{tabular}

We obtained a series of data of high level of homogeneity, almost symmetrical that do not have a significant deviation from normality in both situations (Figure 13). In view of the internalization process, the second variable, having a higher mean, is more convenient for the Romanian public administration.

Figure 13. Histograms $(a, b)$ of the aggregated variables regarding the openness of the administration towards citizens

a)

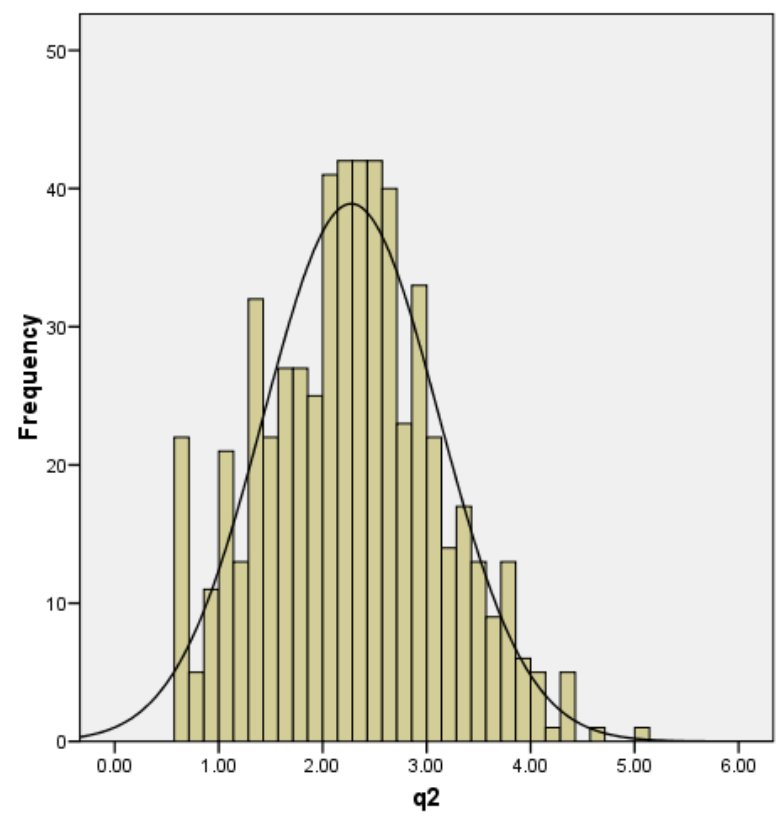

b)

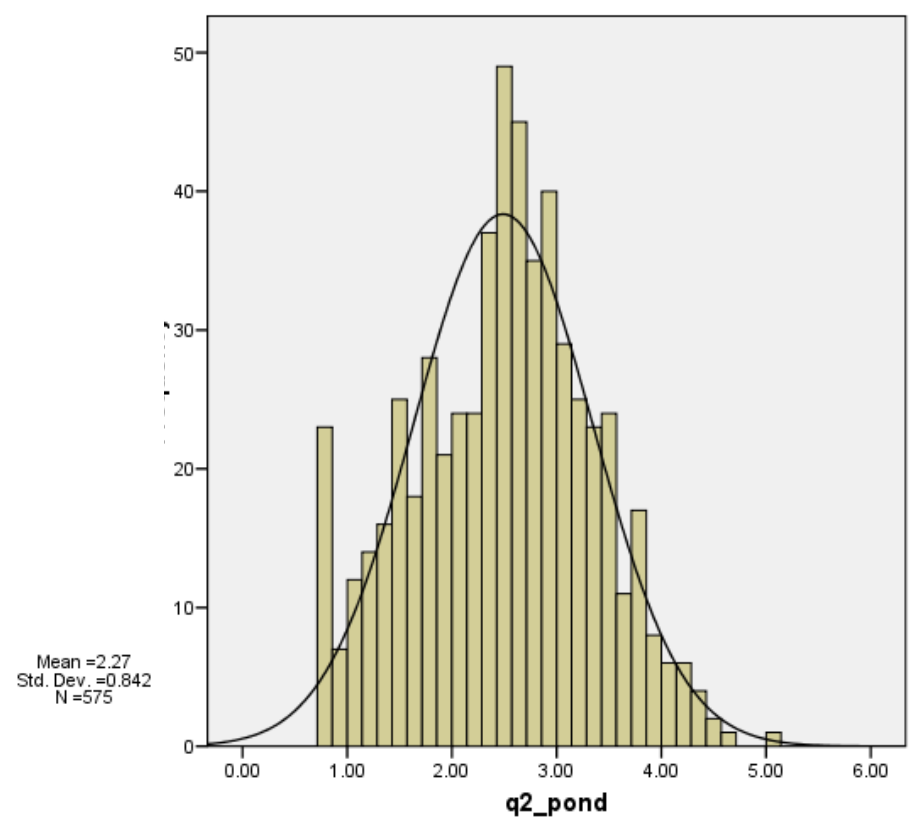




\subsubsection{Self-responsibility of the public administration}

The level 3 aggregated variable to be built, attempts to analyze the internal transformations, specific to administrative organizations that may lead to the increase of internal responsibility and to create the conditions for evolution of the public administration in accordance to the processes of the European Administrative Space.

The independent variables are multiple, and they will lead to:

- evaluation of the responsibility for the administrative "failure" to the European level (q31) or the national one (q32);

- description of the instruments and frequencies of using the latter to the practice of the public administration (q33);

- description of the main characteristics of the civil servants of the national public administrations (q34);

- emphasizing the simpler "ways" to solve the problems raised by citizens (q35);

- self-assessment of the opinions of the public authorities regarding the implication of the citizens in the decision-making process (q36).

a) General, national view of the administrative "failure" in a European country

The administrative "failure" refers to the concept of mal administration, the absence or inconsistency of the democratic procedures of the administrative system, the lack of a strategic vision at central or local level and, of course, the inefficiency of administrative processes. In this context, the variables will empirically evaluate the responsibility specific to the main actors of the decisional and operational bodies of the administration. The assessment offers a comparative landmark for the Romanian public administration, in comparison to 
the perception of the European realities. Table 40 presents the levels of responsibility according to the answers we have received.

Table 40. Distribution of responsibility for the administrative "failure" in any European country

\begin{tabular}{|l|r|r|r|r|}
\hline & \multicolumn{1}{|c|}{$\mathrm{N}$} & \multicolumn{1}{c|}{ Sum } & \multicolumn{1}{c|}{ Mean } & \multicolumn{1}{c|}{$\begin{array}{c}\text { Std. } \\
\text { Deviation }\end{array}$} \\
\hline President of the & 575 & 57.00 & .0991 & .29910 \\
state & 575 & 129.00 & .2243 & .41752 \\
Prime Minister & 575 & 337.00 & .5861 & .49296 \\
Government & 575 & 141.00 & .2452 & .43059 \\
Parliament & 575 & 273.00 & .4748 & .49980 \\
Local authorities & 575 & 162.00 & .2817 & .45024 \\
Civil servants & 575 & 36.00 & .0626 & .24247 \\
Contract-based & 575 & 67.00 & .1165 & .32113 \\
employees & 575 & & & \\
Citizens & & & & \\
Valid N (listwise) & & &
\end{tabular}

As expected, the highest responsibility is placed under the central Government $(58,6 \%)$, the local authorities $(47,5 \%)$ and the civil servants $(28,2 \%)$. It is rather interesting the opinion on the responsibility of the citizens $(11,7 \%)$, far higher than the responsibility placed to the President / leader of the state.

The dependent variable of level 2 will be obtained by aggregating the eight independent variables and the contraction of the results in the interval $[1,5]$.

q31: $N->[1,5]$

$q 31=(q 31 a+q 31 b+q 31 c+q 31 d+q 31 e+q 31 f+q 31 g+q 31 h) * 5 / 8$

The characteristics of the new variable are presented in Table 41.

Table 41. Characteristics of the aggregated variables regarding the general responsibility, in a European country, for the administrative "failure" 


\begin{tabular}{|l|r|c|c|c|}
\hline & \multicolumn{1}{|c|}{$\mathrm{N}$} & Sum & Mean & $\begin{array}{c}\text { Std. } \\
\text { Deviation }\end{array}$ \\
\hline & Statistic & Statistic & Statistic & Statistic \\
\hline q31 & 575 & 751.25 & 1.3065 & .91241 \\
$\begin{array}{l}\text { Valid N } \\
\text { (listwise) }\end{array}$ & 575 & & & \\
\hline
\end{tabular}

\begin{tabular}{|r|r|r|r|r|}
\hline Variance & \multicolumn{2}{|c|}{ Skewness } & \multicolumn{2}{c|}{ Kurtosis } \\
\hline Statistic & \multicolumn{1}{|c|}{ Statistic } & Std. Error & \multicolumn{1}{c|}{ Statistic } & Std. Error \\
\hline .832 & .911 & .102 & 1.205 & .203 \\
& & & & \\
\hline
\end{tabular}

From the cumulated analysis of the answers we observe the opinion expressed towards a collective responsibility (that normally implies two or three actors). Still, the series of data we obtain is not-homogenous, a thing which may mean the responsibility of more than 3 actors. Table 42 presents the frequencies of several cumulated responsibilities.

Table 42. Hierarchy of the cumulative responsibilities for the "failure" of public administration

\begin{tabular}{|l|l|l|l|}
\hline Results & Frequency & Percent & Cumulative percent \\
\hline 0.00 & 59 & 10.3 & 10.3 \\
\hline 1.00 & 176 & 30.6 & 40.9 \\
\hline 2.00 & 138 & 24.0 & 64.9 \\
\hline 3.00 & 116 & 20.2 & 85.1 \\
\hline 4.00 & 48 & 8.3 & 93.4 \\
\hline 5.00 & 27 & 4.7 & 98.1 \\
\hline 6.00 & 6 & 1.0 & 99.1 \\
\hline 7.00 & 1 & 0.2 & 99.3 \\
\hline 8.00 & 4 & 0.7 & 100.00 \\
\hline
\end{tabular}

Figure 14. Histogram of the series of data regarding the responsibility for the "failure" of public administration in a European country 


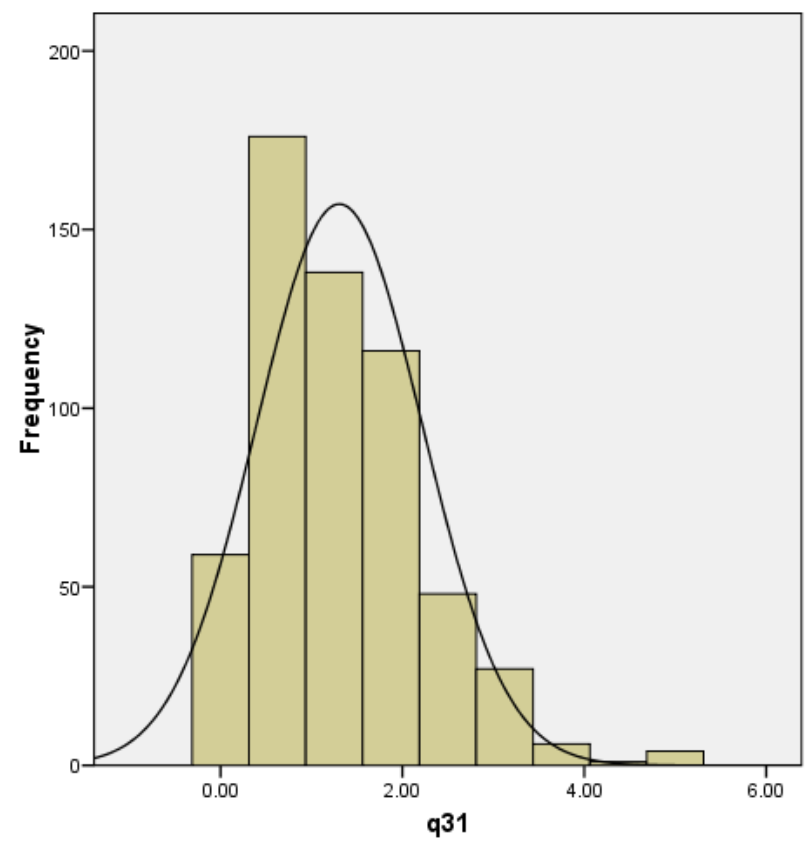

Mean $=1.31$
Std. Dev $=0.912$
$N=575$

The series of data presents a positive Skewness, it not homogenous and is significant deviated from normality.

b) Evaluation of the administrative "failure" in Romania

In the context of understanding the "failure" just in the previous chapter, the actors taken into consideration are the national ones. Table 43 present the levels of responsibility according to the answers provided to our questionnaire.

Table 43. Distribution of responsibilities regarding the "failure" of the Romanian public administration

\begin{tabular}{|l|r|r|r|r|}
\hline & $\mathrm{N}$ & \multicolumn{1}{c|}{ Sum } & \multicolumn{1}{c|}{ Mean } & \multicolumn{1}{c|}{$\begin{array}{c}\text { Std. } \\
\text { Deviation }\end{array}$} \\
\hline President of the & 575 & 84.00 & .1461 & .35350 \\
state & 575 & 156.00 & .2713 & .44502 \\
Prime Minister & 574 & 336.00 & .5854 & .49309 \\
Government & 575 & 172.00 & .2991 & .45828 \\
Parliament & 575 & 288.00 & .5009 & .50043 \\
\hline
\end{tabular}




\begin{tabular}{|l|r|r|r|r|} 
Civil servants & 575 & 171.00 & .2974 & .45751 \\
Contract-based & 575 & 62.00 & .1078 & .31043 \\
employees & 575 & 59.00 & .1026 & .30371 \\
Citizens & 574 & & & \\
Valid N (listwise) & &
\end{tabular}

The most important changes in the views expressed by the answer givers refer to the increase in the complexity of responsibilities with almost $11 \%$, as well as of the President's responsibility (with 4\%), that of the Prime Minister's (with $5 \%$ ), of the Parliament (with 5,5\%), as well as of the other actors, except the citizens.

The aggregated dependent variable of level 2 will be obtained, just as previous, from:

$$
\begin{aligned}
& \text { q32: } N->[1,5] \\
& q 32=(q 32 a+q 32 b+q 32 c+q 32 d+q 32 e+q 32 f+q 32 g+q 32 h) * 5 / 8
\end{aligned}
$$

The characteristics of the new variable are presented in Table 44.

Table 44. Characteristics of the aggregated variables regarding the national responsibility for the administrative "failure"

\begin{tabular}{|l|r|r|r|c|}
\hline & $\mathrm{N}$ & Sum & Mean & $\begin{array}{c}\text { Std. } \\
\text { Deviation }\end{array}$ \\
\hline & Statistic & Statistic & Statistic & Statistic \\
\hline q32 & 574 & 829.38 & 1.4449 & 1.07880 \\
$\begin{array}{l}\text { Valid N } \\
\text { (listwise) }\end{array}$ & 574 & & & \\
\hline
\end{tabular}

\begin{tabular}{|r|r|r|r|r|}
\hline Variance & \multicolumn{2}{|c|}{ Skewness } & \multicolumn{2}{c|}{ Kurtosis } \\
\hline Statistic & Statistic & Std. Error & Statistic & Std. Error \\
\hline 1.164 & .886 & .102 & .484 & .204 \\
& & & & \\
\hline
\end{tabular}

The series of data has a higher mean than in the case of the European level, decreases asymmetrically, and maintains a lower positive Skewness. It also 
increases not-homogenously, but it does not exhibit a significant deviation from normality (see Figure 15).

Just in the European case, the responsibility belongs, in average, to 2 up to 3 actors, but due to a standard deviation, it points to a relevant responsibility of more than four actors. Table 45 presents the frequencies for the cumulated responsibilities.

Table 45. Hierarchy of the cumulative responsibilities for the "failure" of national public administration

\begin{tabular}{|ll|r|r|r|r|}
\hline & & $\begin{array}{r}\text { Frequenc } \\
\text { y }\end{array}$ & Percent & $\begin{array}{c}\text { Valid } \\
\text { Percent }\end{array}$ & $\begin{array}{c}\text { Cumulative } \\
\text { Percent }\end{array}$ \\
\hline Valid & .00 & 65 & 11.3 & 11.3 & 11.3 \\
& 1.00 & 158 & 27.5 & 27.5 & 38.9 \\
& 2.00 & 127 & 22.1 & 22.1 & 61.0 \\
& 3.00 & 103 & 17.9 & 17.9 & 78.9 \\
& 4.00 & 49 & 8.5 & 8.5 & 87.5 \\
& 5.00 & 41 & 7.1 & 7.1 & 94.6 \\
& 6.00 & 17 & 3.0 & 3.0 & 97.6 \\
& 7.00 & 9 & 1.6 & 1.6 & 99.1 \\
& 8.00 & 5 & .9 & .9 & 100.0 \\
& Total & 574 & 99.8 & 100.0 & \\
Missing & System & 1 & .2 & & \\
Total & & 575 & 100.0 & & \\
\hline
\end{tabular}

Figure 15. Histogram of the series of data regarding the national responsibility for the "failure" of public administration 


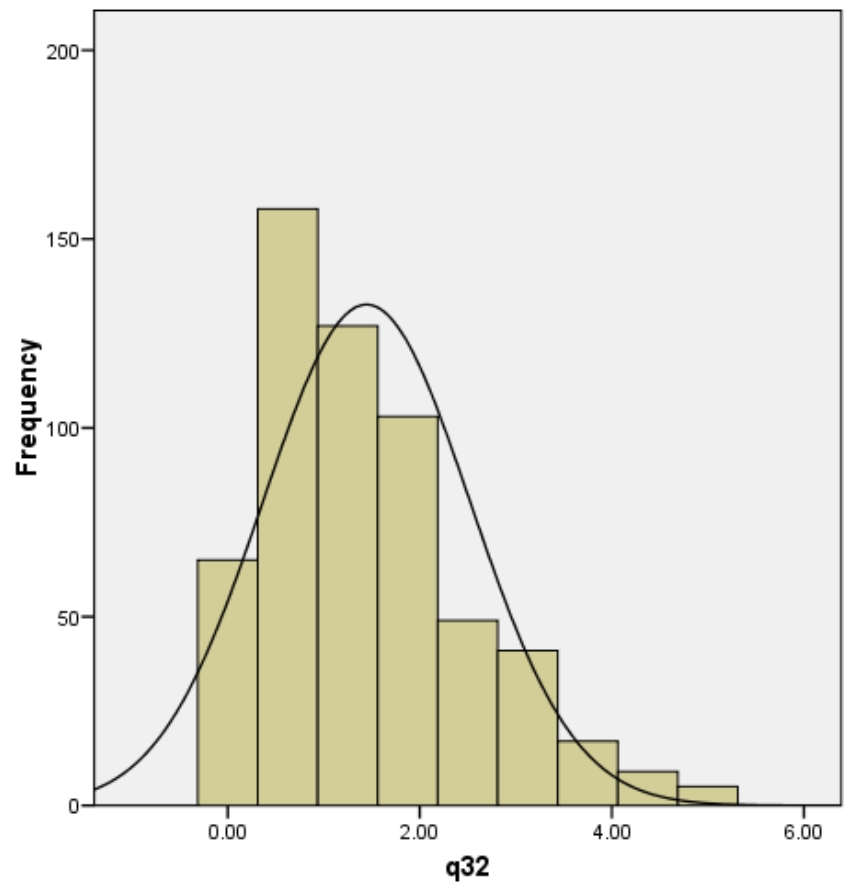

Mean $=1.44$
Std. Dev. $=1.079$
$N=574$

c) Instruments and procedures for the organization of daily public administration activities

The internalization in daily activity of the public administration of several instruments, procedures and best practices of the European administrations of the European Administrative Space represents one of the most important objectives of the diversification and further investigation of the principles of the European Administrative Space.

Analyzing the current activity of several administrations, the present assessment took into account six instruments and procedures relevant to the organization and scientific planning (q33a, q33b), internal audit (q33c), assessment of the employees and their activity (q33d, q33e) and the monitoring of the activities (q33f). The frequencies of the relevant answers are presented in Table 46.

Table 46. Frequencies of the use of instruments and procedures for the planning, organizing, and deployment of activities in the daily activities of the public administration 


\begin{tabular}{|l|r|r|r|r|}
\hline & $\mathrm{N}$ & \multicolumn{1}{c|}{ Sum } & \multicolumn{1}{c|}{ Mean } & \multicolumn{1}{c|}{$\begin{array}{c}\text { Std. } \\
\text { Deviation }\end{array}$} \\
\hline Strategies for labour & 575 & 163.00 & .2835 & .45108 \\
organization & 575 & 225.00 & .3913 & .48847 \\
Action plans & 575 & 236.00 & .4104 & .49234 \\
Missions of internal & 575 & 318.00 & .5530 & .49761 \\
audit & 575 & 200.00 & .3478 & .47670 \\
Assessments of the & & & & .48808 \\
employees & 575 & 224.00 & .3896 & \\
Assessments of the & 575 & & & \\
activities & & &
\end{tabular}

We observe that the most often instruments used are: assessment of the employees (55,3\%), internal audit (41\%) and action plans (39\%). Their high frequency is determined by the necessity to respect several legal provisions specific to public administration in Romania.

As observed in Table 46, the instruments enumerated above are used, most of the times, concomitant. Table 47 presents the cumulated frequencies of those instruments.

Table 47. Hierarchy of the cumulated use of instruments for the organization and deployment of activities in the Romanian public administration

\begin{tabular}{|rl|r|r|r|r|}
\hline & & $\begin{array}{r}\text { Frequenc } \\
\text { y }\end{array}$ & Percent & $\begin{array}{c}\text { Valid } \\
\text { Percent }\end{array}$ & $\begin{array}{c}\text { Cumulative } \\
\text { Percent }\end{array}$ \\
\hline Valid & .00 & 86 & 15.0 & 15.0 & 15.0 \\
& 1.00 & 133 & 23.1 & 23.1 & 38.1 \\
& 2.00 & 118 & 20.5 & 20.5 & 58.6 \\
3.00 & 97 & 16.9 & 16.9 & 75.5 \\
4.00 & 53 & 9.2 & 9.2 & 84.7 \\
5.00 & 34 & 5.9 & 5.9 & 90.6 \\
6.00 & 54 & 9.4 & 9.4 & 100.0 \\
& Total & 575 & 100.0 & 100.0 & \\
\hline
\end{tabular}


One observes the concomitant use of up to three instruments, and the weight of the use of all instruments is relatively low $(9,4 \%)$

The aggregated dependent variable of level 2 is to be obtained just as in the case of the previous situations, by summing and contracting the six variables to the interval $[1,5]$, as follows:

q33: $N->[1,5]$

$q 33=(q 33 a+q 33 b+q 33 c+q 33 d+q 33 e+q 33 f) * 5 / 6$.

The characteristics of the new variable are presented in Table 48.

Table 48. Characteristics of the aggregated variables regarding the instruments used for the planning, organizing, and deployment of activities in the Romanian public administration

\begin{tabular}{|l|r|r|c|c|r|r|r|r|}
\hline & $\mathrm{N}$ & Mean & $\begin{array}{c}\text { Std. } \\
\text { Deviation }\end{array}$ & Variance & \multicolumn{2}{|c|}{ Skewness } & \multicolumn{2}{|c|}{ Kurtosis } \\
\hline & Statistic & Statistic & Statistic & Statistic & Statistic & Std. Error & Statistic & Std. Error \\
\hline q33 & 575 & 1.9797 & 1.50608 & 2.268 & .572 & .102 & -.618 & .203 \\
$\begin{array}{l}\text { Valid N } \\
\text { (listwise) }\end{array}$ & 575 & & & & & & & \\
\hline
\end{tabular}

The series of data has a higher mean and a high distortion which leads us to conclude on their high in homogeneity. The series is asymmetrical and it contains a positive Skeweness and a significant deviation from normality (see Figure 16).

Figure 16. Histogram of the series of data regarding the instruments used in the activity of the public administration 


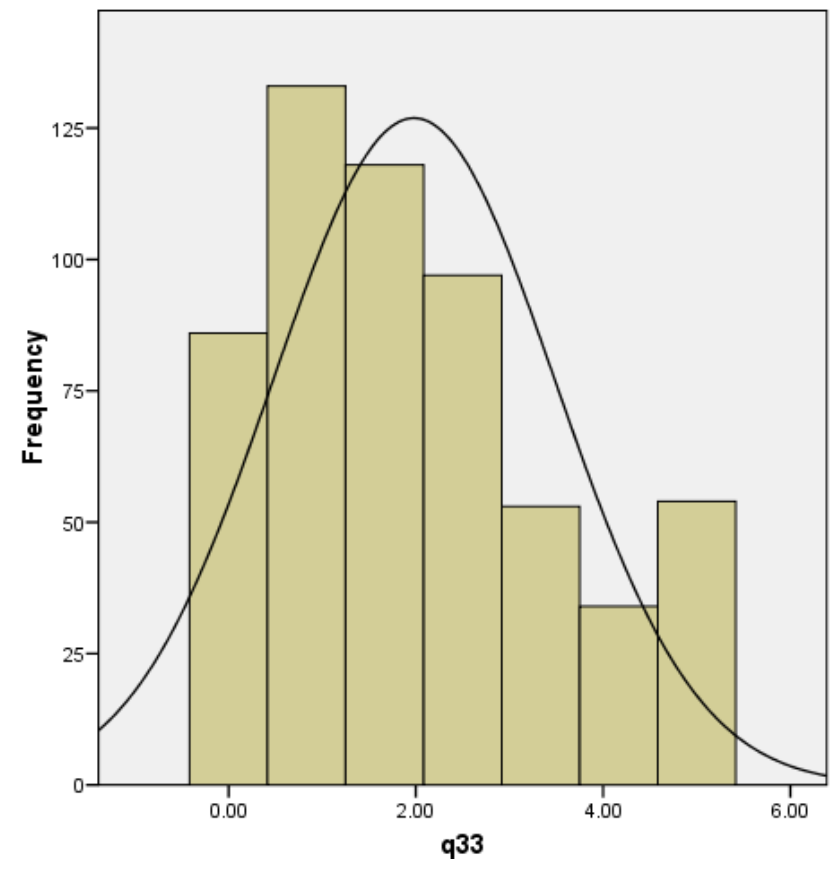

Mean $=1.98$
Std. Dev. $=1.506$
$N=575$

d) Characteristics of the Romanian civil servants

We have included in this study several variables on civil service, based on our conclusion that almost all the studies regarding the public sector reform and public management reform give a special attention to the development of the civil service as a politically independent, meritocratic, professional and ethical service. In this context, we have stopped to six independent variables which in our view are the most relevant for the extension of the European Administrative Space: objectivity (q34a), political independence (q34b), morality (q34c), tolerance (q34d), professionalism (q34e) and integrity (q34f). All their opposite characteristics were also evaluated and presented. Using a bivalent evaluation, we consider the study of the six variables to be relevant (the other variables remained complementary).

Table 49. Frequencies of the characteristics of the civil servants

\begin{tabular}{|l|r|r|r|r|}
\hline & $\mathrm{N}$ & Sum & Mean & $\begin{array}{c}\text { Std. } \\
\text { Deviation }\end{array}$ \\
\hline Objectivity & 575 & 165.00 & .2870 & .45273 \\
\hline
\end{tabular}




\begin{tabular}{|l|l|l|l|l|} 
Political & 575 & 187.00 & .3252 & .46886 \\
independence & 575 & 216.00 & .3757 & .48471 \\
Morality & 575 & 232.00 & .4035 & .49102 \\
Tolerance & 575 & 288.00 & .5009 & .50043 \\
Professionalism & 575 & 146.00 & .2539 & .43563 \\
Integrity & 575 & & & \\
Valid N (listwise) & &
\end{tabular}

One can easily see three important groups for the main characteristics of the civil servants - professionalism and tolerance (40-50\%), morality and political independence (32-37\%) and integrity and objectivity (25-28\%).

Generally, the options were significant increase for professionalism and political independence; this comes as a contradiction with the current academic and public opinion views. This situation may be justified by the fact that our target group was formed out of civil servants (management and operational). Placing together the answers, we find a considerable relevancy to two up to three characteristics (41\%), but also, of all other characteristics $(3,8 \%)$ (see Table 50$)$.

Table 50. Conjugation of the most important features of the civil service

\begin{tabular}{|rl|r|r|r|r|}
\hline & Frequency & Percent & \multicolumn{1}{c|}{$\begin{array}{c}\text { Valid } \\
\text { Percent }\end{array}$} & $\begin{array}{c}\text { Cumulative } \\
\text { Percent }\end{array}$ \\
\hline Valid & .00 & 2 & .3 & .3 & .3 \\
& 1.00 & 245 & 42.6 & 42.6 & 43.0 \\
& 2.00 & 153 & 26.6 & 26.6 & 69.6 \\
3.00 & 85 & 14.8 & 14.8 & 84.3 \\
4.00 & 44 & 7.7 & 7.7 & 92.0 \\
5.00 & 24 & 4.2 & 4.2 & 96.2 \\
6.00 & 22 & 3.8 & 3.8 & 100.0 \\
Total & 575 & 100.0 & 100.0 & \\
\hline
\end{tabular}

The dependent variables of level 2, needed for the aggregated evaluation of the most important features of the civil servants, according to the development principles of the civil service in the European Administrative Space may be obtained as following: 
q34: $N->[1,5]$

$q 34=(q 34 a+q 34 b+q 34 c+q 34 d+q 34 e+q 34 f)^{*} 5 / 6$.

Table 51. Characteristics of the aggregated variable regarding the main characteristics of the civil servants

\begin{tabular}{|l|r|r|c|c|c|r|r|r|}
\hline & $\mathrm{N}$ & Mean & $\begin{array}{c}\text { Std. } \\
\text { Deviation }\end{array}$ & Variance & \multicolumn{2}{|c|}{ Skewness } & \multicolumn{2}{|c|}{ Kurtosis } \\
\hline & Statistic & Statistic & Statistic & Statistic & Statistic & Std. Error & Statistic & Std. Error \\
\hline q34 & 575 & 1.7884 & 1.13763 & 1.294 & 1.210 & .102 & .773 & .203 \\
$\begin{array}{l}\text { Valid N } \\
\text { (listwise) }\end{array}$ & 575 & & & & & & & \\
\hline
\end{tabular}

The series of data we obtained is asymmetrical, with a positive distortion, without any significant deviation from normality. There is a significant not-homogeneity $(38,8 \%)$, justified by a high variance $(1,294)$ (see Figure 17$)$.

Figure 17. Histogram of the series of data regarding the features of the civil servants

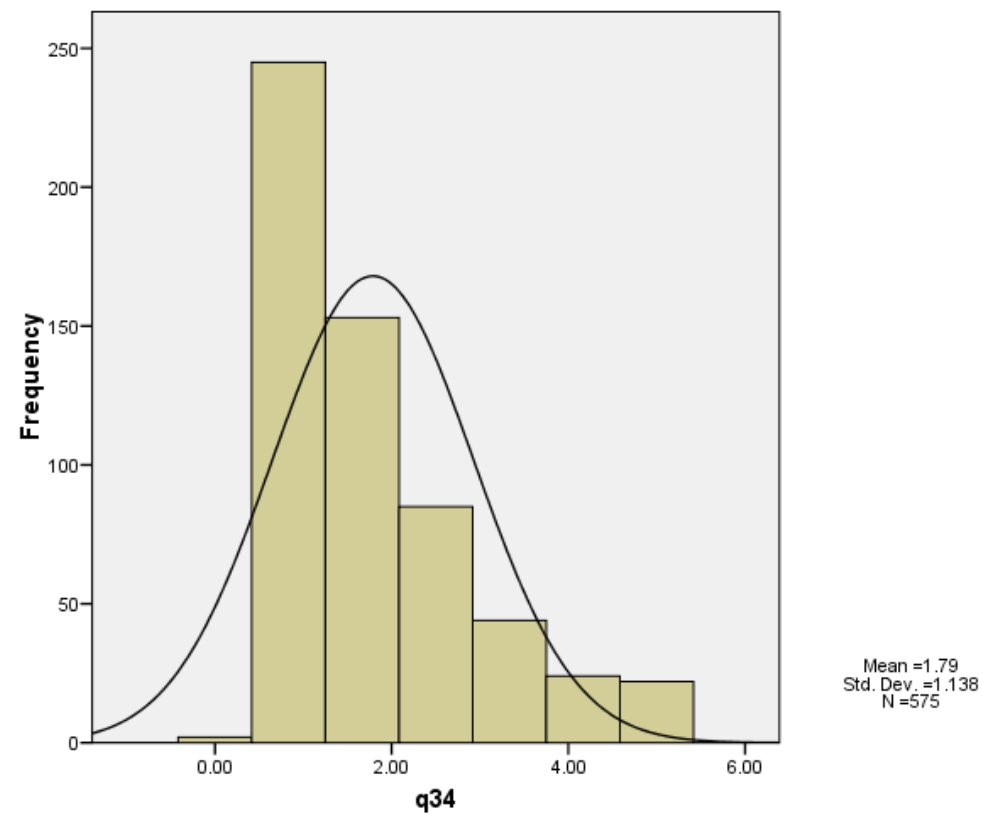

e) Evaluation of preferential attitudes in civil services 
Public administrations in the states that have recently become part of the European Union are suspected, just fully, to have developed favorable attitudes towards certain citizens. This attitude, not in line with the principles of the European Administrative Space, is determined by several causes amongst which, for this present study, we have selected only the following:

1. granting of gifts or mutual services in exchange of public services (q35a);

2. existence of mutual acquaintances or direct connections (friendship relations, family relationships) (q35b);

3. membership in the same party of interest groups (q35c).

Evaluated on a scale of 1 to 5 , the three independent variables can offer us an image of the public perception on these phenomena which, in time, with the development of the European Administrative Space, should diminish. To assess these features, we have employed an inversed scale (top-bottom in reference to the development of the phenomena).

Table 52. Characteristics of the independent variables regarding the preferential attitude in the civil service

\begin{tabular}{|c|c|c|c|c|c|c|c|c|}
\hline & \multirow{2}{*}{$\frac{\mathrm{N}}{\text { Statistic }}$} & \multirow{2}{*}{$\begin{array}{l}\text { Mean } \\
\text { Statistic }\end{array}$} & \multirow{2}{*}{$\begin{array}{c}\text { Std. } \\
\text { Deviation } \\
\text { Statistic }\end{array}$} & \multirow{2}{*}{$\begin{array}{c}\text { Variance } \\
\text { Statistic }\end{array}$} & \multicolumn{2}{|c|}{ Skewness } & \multicolumn{2}{|c|}{ Kurtosis } \\
\hline & & & & & Statistic & Std. Error & Statistic & Std. Error \\
\hline $\begin{array}{l}\text { "The gifts" and/or } \\
\text { "mutual services" }\end{array}$ & 575 & 2.5339 & 1.59763 & 2.552 & .526 & .102 & -1.331 & .203 \\
\hline $\begin{array}{l}\text { To know civil } \\
\text { servants }\end{array}$ & 575 & 2.5774 & 1.57524 & 2.481 & .533 & .102 & -1.309 & .203 \\
\hline $\begin{array}{l}\text { Declared political } \\
\text { affiliation }\end{array}$ & 575 & 2.9270 & 1.60516 & 2.577 & .152 & .102 & -1.567 & .203 \\
\hline Valid N (listwise) & 575 & & & & & & & \\
\hline
\end{tabular}

Even with an inversed scale, we notice that the means of the variables are rather high. Still, the series of data are strongly and positively distorted, a fact explained by offering a level 5 to the answer "I do not know". Analyses using another scale will possible bring better results. The three independent variables are positively correlated; all the coefficients are significant for 0,01 level (Table 53). 
Table 53. Correlations of the independent variables regarding the preferential attitudes in public services

\begin{tabular}{|c|c|c|c|c|}
\hline & & $\begin{array}{l}\text { "The gifts" } \\
\text { and/or } \\
\text { "mutual } \\
\text { services" }\end{array}$ & $\begin{array}{l}\text { To know } \\
\text { civil } \\
\text { servants }\end{array}$ & $\begin{array}{l}\text { Declared } \\
\text { political } \\
\text { affiliation }\end{array}$ \\
\hline $\begin{array}{l}\text { "The gifts" and/or } \\
\text { "mutual services" }\end{array}$ & $\begin{array}{l}\text { Pearson } \\
\text { Correlation } \\
\text { Sig. (2-tailed) } \\
\mathrm{N}\end{array}$ & 575 & $\begin{array}{r}.575\left({ }^{* *}\right) \\
.000 \\
575\end{array}$ & $\begin{array}{r}.441\left({ }^{* *}\right) \\
.000 \\
575\end{array}$ \\
\hline $\begin{array}{l}\text { To know civil } \\
\text { servants }\end{array}$ & $\begin{array}{l}\text { Pearson } \\
\text { Correlation } \\
\text { Sig. (2-tailed) } \\
\mathrm{N}\end{array}$ & $\begin{array}{r}.575\left(^{* *}\right) \\
.000 \\
575\end{array}$ & 575 & $\begin{array}{r}\left..531{ }^{* *}\right) \\
.000 \\
575\end{array}$ \\
\hline $\begin{array}{l}\text { Declared political } \\
\text { affiliation }\end{array}$ & $\begin{array}{l}\text { Pearson } \\
\text { Correlation } \\
\text { Sig. (2-tailed) } \\
\mathrm{N}\end{array}$ & $\begin{array}{r}.441\left(^{* *}\right) \\
.000 \\
575\end{array}$ & $\begin{array}{r}.531\left(^{\star *}\right) \\
.000 \\
575\end{array}$ & 575 \\
\hline
\end{tabular}

In this context, similarly to the previous cases, we will build an aggregated variable of level 2 , as:

1. mean of independent variables: $q 35=(q 35 a+q 35 b+q 35 c) / 3$

2. weighted mean of independent variables: $q 35$ _pond $=0,328 * \mathrm{q} 35 \mathrm{a}$ $+0,357^{*} q 35 b+0,315^{*} q 35 c$.

The characteristics of the two variables are presented in Table 54, a, b.

Table 54 a. Characteristics of the aggregated variable regarding the preferential attitude in public services

\begin{tabular}{|l|r|r|r|r|r|c|}
\hline & \multicolumn{1}{|c|}{$\mathrm{N}$} & Minimum & Maximum & Sum & Mean & $\begin{array}{c}\text { Std. } \\
\text { Deviation }\end{array}$ \\
\cline { 2 - 7 } & Statistic & Statistic & Statistic & Statistic & Statistic & Statistic \\
\hline q35 & 575 & 1.00 & 5.00 & 1540.67 & 2.6794 & 1.31028 \\
$\begin{array}{l}\text { Valid N } \\
\text { (listwise) }\end{array}$ & 575 & & & & & \\
\hline
\end{tabular}




\begin{tabular}{|l|r|r|r|r|r|}
\hline & Variance & \multicolumn{2}{|c|}{ Skewness } & \multicolumn{2}{c|}{ Kurtosis } \\
\hline & Statistic & \multicolumn{1}{|c|}{ Statistic } & Std. Error & \multicolumn{1}{c|}{ Statistic } & Std. Error \\
\hline q35 & 1.717 & .421 & .102 & -1.067 & .203 \\
$\begin{array}{l}\text { Valid N } \\
\text { (listwise) }\end{array}$ & & & & & \\
\hline
\end{tabular}

Table $54 \mathrm{~b}$. Characteristics of the aggregated variable regarding the preferential attitude in public services

\begin{tabular}{|l|r|r|r|r|r|r|}
\hline & $\begin{array}{c}\mathrm{N} \\
\text { Statistic }\end{array}$ & $\begin{array}{c}\text { Minimum } \\
\text { Statistic }\end{array}$ & $\begin{array}{c}\text { Maximum } \\
\text { Statistic }\end{array}$ & $\begin{array}{c}\text { Sum } \\
\text { Statistic }\end{array}$ & $\begin{array}{c}\text { Mean } \\
\text { Statistic }\end{array}$ & $\begin{array}{c}\text { Std. } \\
\text { Deviation } \\
\text { Statistic }\end{array}$ \\
\hline $\begin{array}{l}\text { q35_pond } \\
\text { Valid N } \\
\text { (listwise) }\end{array}$ & 575 & 1.00 & 5.00 & 1537.11 & 2.6732 & 1.31189 \\
\hline
\end{tabular}

\begin{tabular}{|l|r|r|r|r|r|}
\hline & Variance & \multicolumn{2}{|c|}{ Skewness } & \multicolumn{2}{c|}{ Kurtosis } \\
\hline & Statistic & \multicolumn{1}{|c|}{ Statistic } & Std. Error & \multicolumn{1}{c|}{ Statistic } & Std. Error \\
\hline $\begin{array}{l}\text { q35_pond } \\
\text { Valid N } \\
\text { (listwise) }\end{array}$ & 1.721 & .429 & .102 & -1.069 & .203 \\
\hline
\end{tabular}

The presented characteristics are not significantly different, but present a positive distortion and a deviation from normality.

Figure 18. Histogram of the series of data regarding the preferential attitude in the civil service

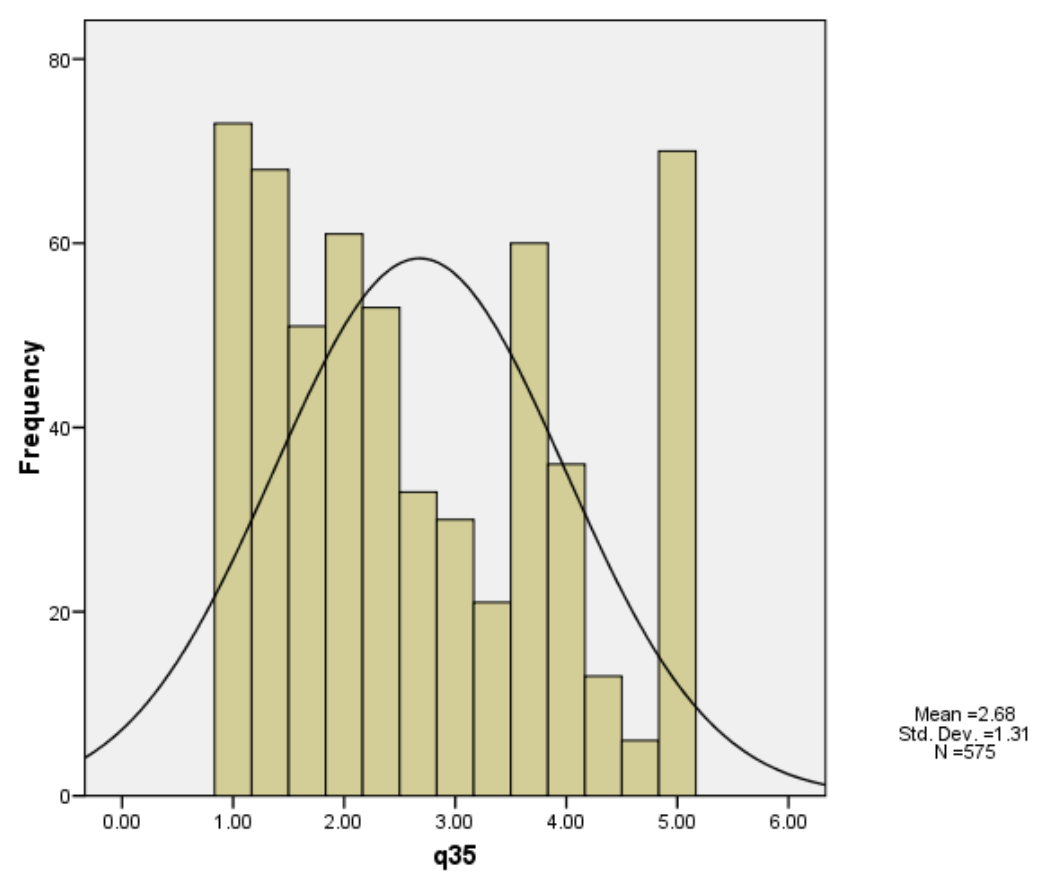


f) Perception on the impact of the citizens on decision-making process

The implication of citizens in the decision-making process is clearly established in the Romanian legal provisions. The studies and analyses reveal an attitude, not quite favorable, of the public administrators. As such, the variable is quite relevant, and it evaluates the negative perception the citizens have in connection to the public authorities.

The independent variables separately evaluate:

1. "the discontent" with regard to the administrative actions due to the citizens' involvement in the decision-making process (q36a);

2. "the delay" in taking a decision due to the involvement of citizens in the decision-making process (q36b);

3. "the lack of practical utility" of the involvement of citizens in the decisionmaking process (q36c).

Given the lack of compatibility with the principles of the European Administrative Space, the evaluation scale of the variables was also set in a top to bottom perspective. The characteristics of the three independent variables are presented in Table 55.

Table 55. Characteristics of the independent variables regarding the impact of citizens to the decision-making process

\begin{tabular}{|l|r|c|c|c|}
\hline & $\mathrm{N}$ & Sum & Mean & $\begin{array}{c}\text { Std. } \\
\text { Deviation }\end{array}$ \\
\hline & Statistic & Statistic & Statistic & Statistic \\
\hline $\begin{array}{l}\text { Enhances the } \\
\text { degree of } \\
\text { dissatisfaction } \\
\text { concerning the }\end{array}$ & 575 & 1951.00 & 3.3930 & 1.52743 \\
$\begin{array}{l}\text { actions of } \\
\text { administration } \\
\begin{array}{l}\text { Postpones a } \\
\text { concrete decision- } \\
\text { making }\end{array}\end{array}$ & 575 & 1944.00 & 3.3809 & 1.49540 \\
\hline
\end{tabular}


Consumes the resources of administration, without proving its practical utility Valid N (listwise)

\begin{tabular}{|l|l|l|l|}
575 & 2088.00 & 3.6313 & 1.42760 \\
& & & \\
\hline
\end{tabular}

\begin{tabular}{|r|r|r|r|r|}
\hline Variance & \multicolumn{2}{|c|}{ Skewness } & \multicolumn{2}{c|}{ Kurtosis } \\
\hline \multicolumn{1}{c|}{ Statistic } & \multicolumn{1}{|c|}{ Statistic } & Std. Error & \multicolumn{1}{c|}{ Statistic } & Std. Error \\
\hline 2.333 & -.222 & .102 & -1.519 & .203 \\
2.236 & -.173 & .102 & -1.487 & .203 \\
2.038 & -.483 & .102 & -1.216 & .203 \\
\hline
\end{tabular}

The means of the three variables remain high, a fact which situates the attitudes of the authorities between level 3 and 4, meaning, between "rather disagree" and "total disagreement". Also, the Pearson correlations are positive, have average intensity and are significant at 0.01 level (Table 56).

Table 56. Statistical Pearson Correlations between independent variables on the impact of the citizens to the decision-making process

\begin{tabular}{|c|c|c|c|c|}
\hline & & $\begin{array}{l}\text { Enhances the } \\
\text { degree of } \\
\text { dissatisfactio } \\
\mathrm{n} \text { concerning } \\
\text { the actions of } \\
\text { administration }\end{array}$ & $\begin{array}{l}\text { Postpones a } \\
\text { concrete } \\
\text { decision- } \\
\text { making }\end{array}$ & $\begin{array}{c}\text { Consumes } \\
\text { the resources } \\
\text { of } \\
\text { administration } \\
\text {, without } \\
\text { proving its } \\
\text { practical } \\
\text { utility }\end{array}$ \\
\hline \multirow{3}{*}{$\begin{array}{l}\text { Enhances the degree of } \\
\text { dissatisfaction } \\
\text { concerning the actions } \\
\text { of administration }\end{array}$} & Pearson & 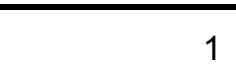 & $\left..397^{(* *}\right)$ & $.434\left(^{* *}\right)$ \\
\hline & $\begin{array}{l}\text { Correlation } \\
\text { Sig. (2-tailed) }\end{array}$ & & .000 & .000 \\
\hline & $N$ & 575 & 575 & 575 \\
\hline \multirow[t]{3}{*}{$\begin{array}{l}\text { Postpones a concrete } \\
\text { decision- making }\end{array}$} & $\begin{array}{l}\text { Pearson } \\
\text { Correlation }\end{array}$ & $.397\left(^{* *}\right)$ & 1 & $\left..501{ }^{* *}\right)$ \\
\hline & Sig. (2-tailed) & .000 & & .000 \\
\hline & $\mathrm{N}$ & 575 & 575 & 575 \\
\hline $\begin{array}{l}\text { Consumes the } \\
\text { resources of }\end{array}$ & $\begin{array}{l}\text { Pearson } \\
\text { Correlation }\end{array}$ & $.434\left({ }^{* *}\right)$ & $.501\left(^{* *}\right)$ & 1 \\
\hline administration, without & Sig. (2-tailed) & .000 & .000 & \\
\hline
\end{tabular}


proving its practical utility
$\mathrm{N}$

** Correlation is significant at the 0.01 level (2-tailed).

In this context, similarly to the previous procedures, we will build an aggregated variable which represents the mean of the three variables. A possible variable built as a weighted mean will not produce any significant results:

$q 36=(q 36 a+q 36 b+q 36 c) / 3$

Table 57. Characteristics of the aggregated variables regarding the impact of the citizens to the decision-making process

\begin{tabular}{|l|r|r|c|c|r|r|r|r|}
\hline & $\mathrm{N}$ & Mean & $\begin{array}{c}\text { Std. } \\
\text { Deviation }\end{array}$ & Variance & \multicolumn{2}{|c|}{ Skewness } & \multicolumn{2}{|c|}{ Kurtosis } \\
\hline & Statistic & \multicolumn{1}{|c|}{ Statistic } & Statistic & Statistic & Statistic & Std. Error & Statistic & Std. Error \\
\hline q36 & 575 & 3.4684 & 1.17634 & 1.384 & -.110 & .102 & -1.153 & .203 \\
$\begin{array}{l}\text { Valid N } \\
\text { (listwise) }\end{array}$ & 575 & & & & & & & \\
\hline
\end{tabular}

The aggregated variables are listed within the margins of the independent variables. The series of data presents the lack of homogeneity due to the high frequency of the scale 5, the "not know" answers. Just as in the previous chapter, it is necessary to rebuild the scaling of the variable. The series of data present a strong asymmetry, it has a positively distortion and it has a significant deviation from normality (Figure 19).

Figure 19. Histogram of the series of data regarding the impact of the citizens' involvement in the decision-making process 


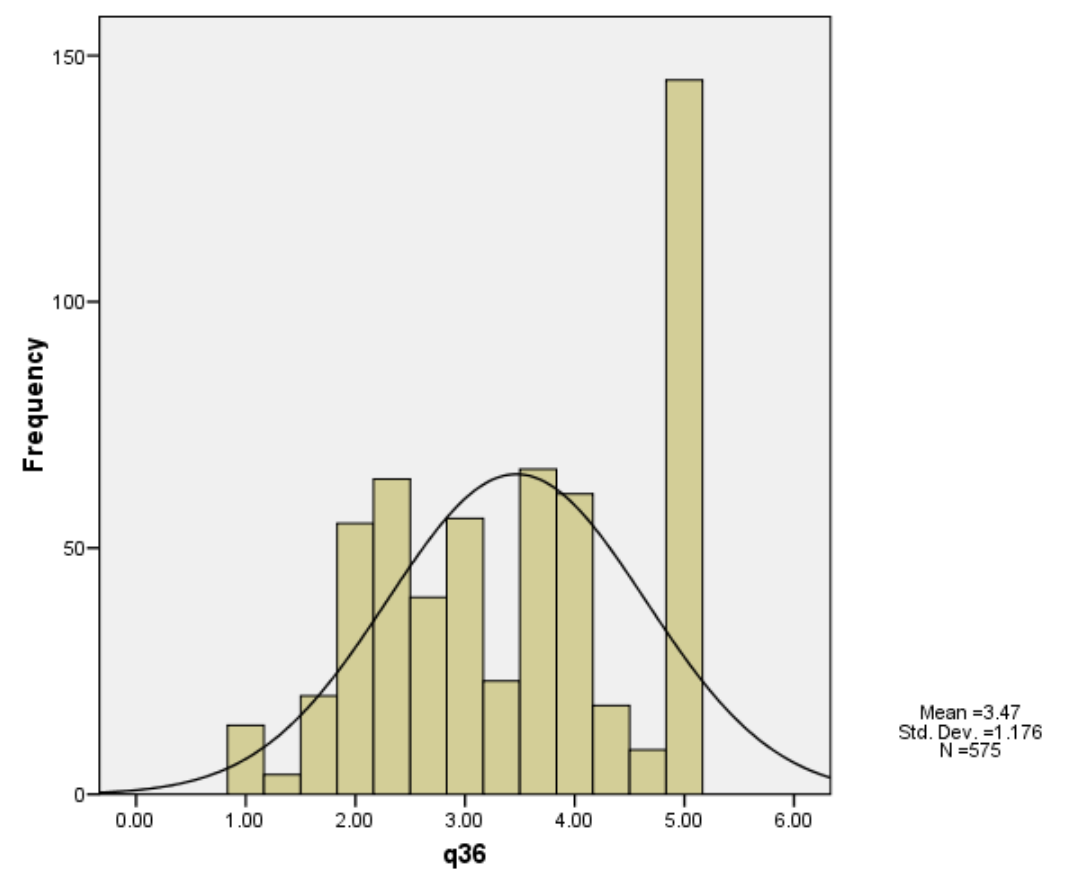

g) Partial conclusions (3)

The partial conclusions refer to the use of the variables analyzed in this section for the assessment of the level of internalization of the European Administrative Space's principles. Amongst the six variables of level 2 we have analyzed, one in particular, q31 has the right features for a control variable, with the role in offering a relatively standard regarding the developing trends of the Romanian public administration.

The correlations between variables $q 31$ and $q 32$ are strong $(0,755)$; this is compatible with the developments of the European and national public administrations.

As such, in order to assess the self-responsibility of the public administration, we will use five variables, q32, q33, q34, q35 and q36. The correlations between these five aggregated variables are presented in Table 58. 
Table 58. Statistical Pearson correlations of the variables assessing the selfresponsibility of the public administration

\begin{tabular}{|c|c|c|c|c|c|c|}
\hline & & q32 & q33 & q34 & q35 & $q 36$ \\
\hline \multirow[t]{3}{*}{$q 32$} & $\begin{array}{l}\text { Pearson } \\
\text { Correlation }\end{array}$ & 1 & $\left..180^{* \star}\right)$ & .065 & $-.429\left({ }^{* *}\right)$ & $-.259\left({ }^{* *}\right)$ \\
\hline & Sig. (2-tailed) & & .000 & .121 & .000 & .000 \\
\hline & $\mathrm{N}$ & 574 & 574 & 574 & 574 & 574 \\
\hline \multirow[t]{3}{*}{ q33 } & $\begin{array}{l}\text { Pearson } \\
\text { Correlation }\end{array}$ & $.180\left({ }^{* *}\right)$ & 1 & $.187\left(^{* *}\right)$ & $-.128\left(^{(* *}\right)$ & $-.116\left({ }^{* *}\right)$ \\
\hline & Sig. (2-tailed) & .000 & & .000 & .002 & .005 \\
\hline & $\mathrm{N}$ & 574 & 575 & 575 & 575 & 575 \\
\hline \multirow[t]{3}{*}{ q34 } & $\begin{array}{l}\text { Pearson } \\
\text { Correlation }\end{array}$ & .065 & $\left..187^{* *}\right)$ & 1 & $\left..1511^{* *}\right)$ & .004 \\
\hline & Sig. (2-tailed) & .121 & .000 & & .000 & .931 \\
\hline & $\mathrm{N}$ & 574 & 575 & 575 & 575 & 575 \\
\hline \multirow[t]{3}{*}{ q35 } & $\begin{array}{l}\text { Pearson } \\
\text { Correlation }\end{array}$ & $-.429\left({ }^{* \star}\right)$ & $-.128\left(^{(* *}\right)$ & $\left..1511^{(* *}\right)$ & 1 & $.468\left(^{* *}\right)$ \\
\hline & Sig. (2-tailed) & .000 & .002 & .000 & & .000 \\
\hline & $\mathrm{N}$ & 574 & 575 & 575 & 575 & 575 \\
\hline \multirow[t]{3}{*}{ q36 } & $\begin{array}{l}\text { Pearson } \\
\text { Correlation }\end{array}$ & $-.259\left({ }^{* *}\right)$ & $-.116\left(^{* *}\right)$ & .004 & $.468\left({ }^{* *}\right)$ & 1 \\
\hline & Sig. (2-tailed) & .000 & .005 & .931 & .000 & \\
\hline & $\mathrm{N}$ & 574 & 575 & 575 & 575 & 575 \\
\hline
\end{tabular}

** Correlation is significant at the 0.01 level (2-tailed).

The correlations, significant for level 0,01 are different, both in terms of orientation and intensity. The negative correlations, in our opinion, are influenced, just as previously shown, by the "not know" answer. A re-scaling may bring the correlations in real margins. In this context, unlike other chapters, we will not calculate regressions to determine the linear dependencies between variables. Also, in the same context, the construction of the aggregated variable of level 3 regarding the self-responsibility of the public administration represents the statistical mean of the five variables above mentioned.

Table 59. Characteristics of the aggregated variable self responsibility of the public administration

\begin{tabular}{|c|c|c|}
\hline & $\mathrm{N}$ & \\
\hline & & \\
\hline
\end{tabular}




\begin{tabular}{|l|l|l|l|l|l|l|l|l|}
\hline q3 & 574 & 2.2727 & .57768 & .334 & .310 & .102 & -.020 & .204 \\
$\begin{array}{l}\text { Valid N } \\
\text { (listwise) }\end{array}$ & 574 & & & & & & & \\
\hline
\end{tabular}

The series of data we have obtained benefit from a proper level of homogeneity, its has a positive distortion and does not deviate from normality (Figure 20).

Figure 20. Histogram of the series of data regarding the self-responsibility of the public administration

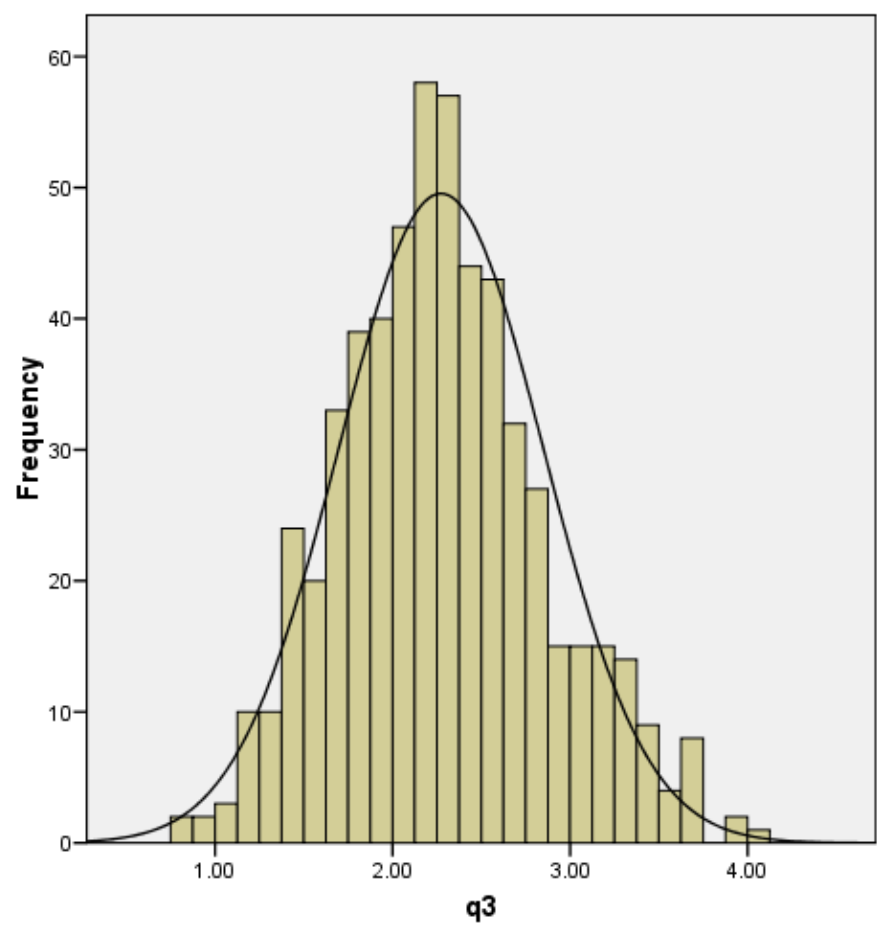

Mean $=2.27$
Std. Dev. $=0.578$
$N=574$ 


\section{List of References}

Ágh, A. (coord.). 2005. Institutional Design and Regional Capacity - Building in the Post-Accession Period, Budapest: Hungarian Centre for Democracy Studies.

Andersen, S.S. 2004. The Mosaic of Europeanization. An Organizational Perspective on National Re-contextualization. ARENA Working Papers, WP 04/11, Oslo: Centre for European Studies.

Andrei, T.; Bourbonnais, R. 2008. „Econometrie”, Bucharest: The Economica Publishing House.

Bomberg, E.; Peterson, J. 2000. Policy Transfer and Europeanization: Passing the Heineken Test?, paper for the 50th Annual Conference of Political Studies Association - UK, April 2000.

Börzel, T.A.; Risse, T. 2000. „When Europe Hits Home: Europeanization and Domestic Change", European Integration online Papers, vol. 4, nr. 15.

Bulmer, S.; Radaelli, C.M. 2004. „The Europeanisation of National Policy?”, Queen's Papers on Europeanisation, no.1/2004.

Cortell, A.; Davis, J. W. 1996. „How do International Institutions Matter? The Domestic Impact of International Rules and Norms", International Studies Quarterly, nr. 40, pp. 451-478.

Demmke, C. 2004. Functia publica europeana (The European civil service), Bucharest: Economica Publishing House.

Dimitrova, A. 2002. „Enlargment, Institution-Building and the EU's Administrative Capacity Requirement", West European Politics, Vol.25, nr.4, Frank Cass, pp.171-190.

Featherstone, K.; Radaelli, C.M. 2003. The Politics of Europeanisation. Oxford: Oxford University Press. 
Fournier, J. 1998. „Governance and European Integration — Reliable Public Administration", SIGMA Papers nr.23, "Preparing public administrations for the European Administrative Space", pp.119-135.

Granell, F. 1995. „The European Union's Enlargement Negotiations with Austria, Finland, Norway and Sweden", Journal of Common Market Studies, Vol 22, Nr. 1 (martie), pp.117-141.

Hoffman, O. 2004. Sociology of organizations (Romanian translation). Bucharest: Economica Publishing House.

Huizingh, E. 2007. Applied Statistics with SPSS. London: Sage Publications.

Iancu, D.C. 2010. Uniunea Europeana si administratia publica (European Union and public administration). lasi: Polirom Publishing House.

Knill, C.; Lehmkuhl, D. 1999. „How Europe Matters. Different Mechanisms of Europeanization", European Integration online Papers, vol. 3, nr.7.

Ladrech, R. 1994. „The Europeanization of Domestic Politics and Institutions: The Case of France", Journal of Common Market Studies 32(1): pp. 6988.

Laegreid, P. 2000. Europeanization and Domestic Administrative Response Adaptation Pressure, Structural Features and Adaptive Behavior, ARENA seminar - Oslo 21.11.2000.

Matei, A., Matei, L. 2009. The Systemic Acquis of Public Administration, available at http://ssrn.com/abstract=1503410.

Matei, A., Matei, L., Săvulescu, C. 2010. „Local Development. Theoretical and Empirical Models", Saarbrücken: Lambert Academic Publishing.

Matei, A., Săvulescu, C. 2010. „System Analysis - Support of the European Administrative Space”, Workshop „Public Administration in the Balkams from Weberian Bureaucracy to the New Public Management", Athens, Greece, 5 - 6 February.

Matei, A.; Matei, L. 2010. European Administration. Normative Fundaments and Systemic Models, available at SSRN: http://ssrn.com/abstract=1651782. 
Matei, A.; Rosca, I.; Tudorel, A. 2009. The Corruption. An Economic and Social Analysis. Bucharest: Economica Publishing House.

Matei, L. lancu, D.C. 2010. "On the way to modernization: "good enough" governance in Romania", International Journal of Regulation and Governance, nr.10, vol. 6.

Matei, L., (ed). 2005. „European Administration Contemporary Concepts and Approaches", Bucharest: Economica Publishing House.

Matei, L., lancu, D. C. 2009. Procese fundamentale ale europenizării administraţiei publice (Fundamental processes of Europeanization of public administration), Bucharest: Economica Publishing House.

Matei, L., Matei, A. 2008. "Globalization and Europeanization - A Projection on a European Model of Public Administration", Theoretical and Applied Economics, Vol. 4, Nr. 4.

Matei, L.; lancu, D.C. 2007. „Delimitări teoretice: europenizarea administraţiei publice şi pârghiile sale instituţionale" (Theoretical delimitations: The europeanization of public administration and its institutional levers), Economie teoretică şi aplicată - supliment („Integrarea României în Uniunea Europeană. Oportunităţi şi ameninţări”, vol.1), April 2007, Bucureşti, pp.93-112.

OECD. 1999. "European Principles for Public Administration", SIGMA Papers, No. 27.

Olsen, J. P. 2002. "The Many Faces of Europeanization", Journal of Common Market Studies nr.40/5, pp.921-952.

Radaelli, C.M. 2000. „Whither Europeanization? Concept stretching and substantive change", European Integration online Papers, vol. 4, nr. 8.

Sedelmeier, U. 2006. „Europeanisation in new member and candidate states”, Living Reviews in European Governance, vol.1, nr.3. 
5. Annex 


\section{Questionnaire}

\section{q1: Rule of law}

q11. In your opinion, the current legislation applicable to the public administration in your country is ... (tick the alternatives applying for $a, b, c$ and $d$ ):

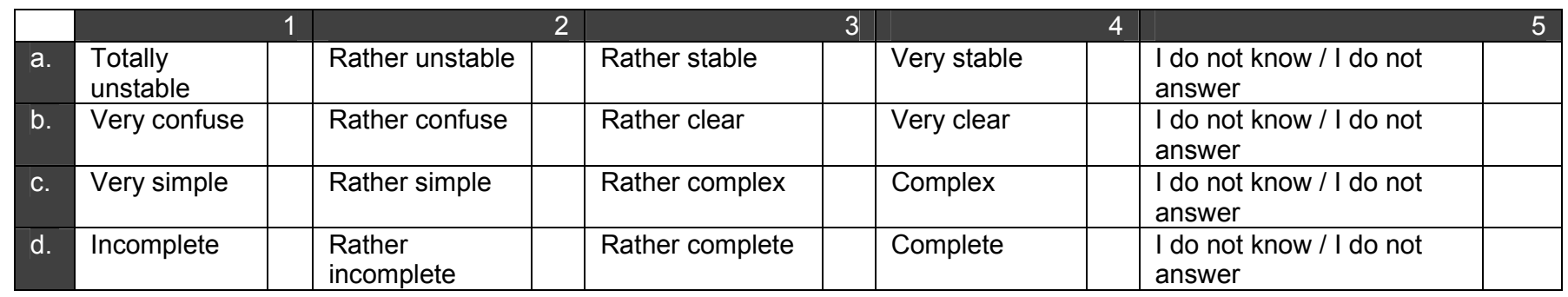

q12. In your opinion, in terms of legislation, in view to eliminate the deficiencies in the national administrative system, it is necessary ... (please tick the alternatives that apply. More answers are possible):

Domestic political consensus concerning the rules applicable to the public administration

Rigorous control of the legality of administrative acts

Speeding the procedure to adopt the rules applicable to the public administration

Strict supervision of enforcement of the administrative rules

Others (please mention).

q13. Taking into consideration your professional experience in enforcing the administrative rules specific to the public administration, you witness.... (please tick the alternatives that apply. More answers are possible):

a. The existence in the same time of contradictory legal provisions

b. The existence in the same time of contradictory methodologies for law enforcement

c. The lack of the legislative framework necessary for efficient delivery of administrative activities

d. The lack of methodology for applying the provisions in force

q14. In your opinion, in terms of legislation, for a better delivery of the activity within the public administration, it is necessary.... (please tick the alternatives that apply. More answers are possible):

a. Stabilization of the normative framework in force

b. Regulation of new administrative realities

c. Increasing the complexity of the legal provisions

d. A better correlation of the legislative provisions

q15. Generally, how would you appreciate the stability of the legislative framework?

a. If the rules are in force for over 10 years, the legislative framework is stable

b. If the rules are in force for over 5 years, the legislative framework is stable

c. If the rules are in force for over 1 year, the legislative framework is stable

\section{q2: Openness towards the citizen}


q21. In your opinion, to what extent the following statements are applicable to the public administration in your country? (please tick the alternatives that apply)

\begin{tabular}{|c|c|c|c|c|c|c|}
\hline & & 1 & 2 & 3 & 4 & 5 \\
\hline & & $\begin{array}{l}\text { To a very } \\
\text { low extent }\end{array}$ & $\begin{array}{l}\text { Rather to a } \\
\text { low extent }\end{array}$ & $\begin{array}{l}\text { Rather to a } \\
\text { large extent }\end{array}$ & $\begin{array}{l}\text { To a very } \\
\text { large extent }\end{array}$ & $\begin{array}{l}\text { I do not } \\
\text { know / I do } \\
\text { not answer }\end{array}$ \\
\hline a. & Administration is serving the citizen & & & & & \\
\hline b. & $\begin{array}{l}\text { In relation to public authorities the } \\
\text { citizens are not discriminated }\end{array}$ & & & & & \\
\hline C. & All citizens are equal before the law & & & & & \\
\hline
\end{tabular}

q22. In your opinion, to what extent the following statements are applicable to the public administration in EU-15 (France, United Kingdom, Germany, Italy, Spain, Portugal, Greece, Ireland, Austria, Belgium, Luxembourg, The Netherlands, Sweden, Denmark, Finland)? (please tick the alternatives that apply)

\begin{tabular}{|c|c|c|c|c|c|c|}
\hline & 1 & 2 & 3 & 4 & 5 \\
\hline & & $\begin{array}{l}\text { To a very } \\
\text { low extent }\end{array}$ & $\begin{array}{l}\text { Rather to a } \\
\text { low extent }\end{array}$ & $\begin{array}{l}\text { Rather to a } \\
\text { large extent }\end{array}$ & $\begin{array}{l}\text { To a very } \\
\text { large extent }\end{array}$ & $\begin{array}{l}\text { I do not } \\
\text { know / I do } \\
\text { not answer }\end{array}$ \\
\hline a. & Administration is serving the citizen & & & & & \\
\hline b. & $\begin{array}{l}\text { In relation to public authorities the } \\
\text { citizens are not discriminated }\end{array}$ & & & & & \\
\hline c. & All citizens are equal before the law & & & & & \\
\hline
\end{tabular}

q23. Based on your professional experience, within the relation with the citizens, the public administration in your country ensures ... (please tick the alternatives that apply):

\begin{tabular}{|c|c|c|c|c|c|c|}
\hline & 1 & 2 & 3 & 4 & 5 \\
\hline & & $\begin{array}{l}\text { To a very low } \\
\text { extent }\end{array}$ & $\begin{array}{l}\text { Rather to a } \\
\text { low extent }\end{array}$ & $\begin{array}{l}\text { Rather to a } \\
\text { large extent }\end{array}$ & $\begin{array}{l}\text { To a very } \\
\text { large extent }\end{array}$ & $\begin{array}{l}\text { I do not } \\
\text { know / I do } \\
\text { not answer }\end{array}$ \\
\hline a. & Religious non - discrimination & & & & & \\
\hline b. & Ethnical non - discrimination & & & & & \\
\hline C. & Gender non - discrimination & & & & & \\
\hline d. & Sexual non - discrimination & & & & & \\
\hline e. & $\begin{array}{l}\text { Non - discrimination of persons } \\
\text { with disabilities }\end{array}$ & & & & & \\
\hline
\end{tabular}

q24. In your opinion, which of the following features characterise the public administration system in your country? (please tick the alternatives that apply. More answers are possible)

\begin{tabular}{|l|l|l|l|l|}
\hline & \multicolumn{2}{|l|}{} & & \\
\hline a. & Institutional transparency & & i. & Institutional opacity \\
\hline b. & Procedural simplicity & & j. & Procedural complexity \\
\hline c. & Efficiency & k. & Inefficiency \\
\hline d. & Organizational dynamism & I. & Organizational rigidity \\
\hline e. & Coherence of actions & m. & Incoherence of actions \\
\hline f. & Procedural equity & n. & Procedural non-equity \\
\hline g. & Decisional objectivity & o. & Decisional subjectivity \\
\hline h. & Political independence & p. & Political servility \\
\hline
\end{tabular}

\section{q3: Self-responsibility of the public administration}


q31. Generally, in a European country, the responsibility for the failures of public administration as a whole belongs to ... (please tick the alternatives that apply. More answers are possible):

\begin{tabular}{|l|l|l|}
\hline & \multicolumn{2}{|l|}{} \\
\hline a. & President of the state & \\
\hline b. & Prime Minister & \\
\hline c. & Government & \\
\hline d. & Parliament & \\
\hline e. & Local authorities & \\
\hline f. & Civil servants & \\
\hline g. & Contract-based employees & \\
\hline h. & Citizens & \\
\hline
\end{tabular}

q32. For your country, the responsibility for the failures of public administration as a whole belongs to... (please tick the alternatives that apply. More answers are possible):

\begin{tabular}{|l|l|l|}
\hline & & \\
\hline a. & President of the state & \\
\hline b. & Prime Minister & \\
\hline c. & Government & \\
\hline d. & Parliament & \\
\hline e. & Local authorities & \\
\hline f. & Civil servants & \\
\hline g. & Contract-based employees & \\
\hline h. & Citizens & \\
\hline
\end{tabular}

q33. In your institution, the following are achieved periodically ... (please tick the alternatives that apply. More answers are possible):

\begin{tabular}{|l|l|l|}
\hline & \multicolumn{2}{|c|}{} \\
\hline a. & Strategies for labour organization & \\
\hline b. & Action plans & \\
\hline c. & Missions of internal audit & \\
\hline d. & Assessments of the employees & \\
\hline e. & Assessments of the activities & \\
\hline f. & Monitoring the ongoing activities & \\
\hline
\end{tabular}

q34. In your opinion, which of the following features characterise the civil servants in your country? (please tick the alternatives that apply. More answers are possible)

\begin{tabular}{|l|l|l|l|l|l|}
\hline & \multicolumn{2}{|l|}{} & & \\
\hline a. & Objectivity & g. & Subjectivity \\
\hline b. & Political independence & h. & Political servilism \\
\hline c. & Morality & i. & Immorality & \\
\hline d. & Tolerance & j. & Intolerance & \\
\hline e. & Professionalism & k. & Lack of professionalism \\
\hline f. & Integrity & & I. & Corruption & \\
\hline
\end{tabular}

q35. In solving a matter with administrative specificity, do you consider that ... (please tick the alternatives that apply):

\begin{tabular}{|c|c|c|c|c|c|c|}
\hline & 1 & 2 & 3 & 4 & 5 \\
\hline & & $\begin{array}{l}\text { To a very } \\
\text { low extent }\end{array}$ & $\begin{array}{l}\text { Rather to a } \\
\text { low extent }\end{array}$ & $\begin{array}{l}\text { Rather to a } \\
\text { large extent }\end{array}$ & $\begin{array}{l}\text { To a very } \\
\text { large extent }\end{array}$ & $\begin{array}{l}\text { I do not } \\
\text { know / I do } \\
\text { not answer }\end{array}$ \\
\hline a. & $\begin{array}{l}\text { "The gifts" and/or „mutual services” } \\
\text { enhance the civil servants' kindness }\end{array}$ & & & & & \\
\hline b. & $\begin{array}{l}\text { To know civil servants in the system } \\
\text { means to have an advantage }\end{array}$ & & & & & \\
\hline C. & $\begin{array}{l}\text { Declared political affiliation may } \\
\text { hasten or slow the progress of }\end{array}$ & & & & & \\
\hline
\end{tabular}


q36. In your opinion, taking into consideration the administrative practice in your country, the citizens' involvement in the decision-making process... (please tick the alternatives that apply):

\begin{tabular}{|c|c|c|c|c|c|c|}
\hline & & 1 & 2 & 3 & 4 & 5 \\
\hline & & $\begin{array}{l}\text { Total } \\
\text { disagreement }\end{array}$ & $\begin{array}{l}\text { Rather } \\
\text { disagree }\end{array}$ & Rather agree & $\begin{array}{l}\text { Total } \\
\text { agreement }\end{array}$ & $\begin{array}{l}\text { I do not } \\
\text { know / I do } \\
\text { not answer }\end{array}$ \\
\hline a. & $\begin{array}{l}\text { Enhances the degree of } \\
\text { dissatisfaction concerning the } \\
\text { actions of administration }\end{array}$ & & & & & \\
\hline b. & $\begin{array}{l}\text { Postpones a concrete decision- } \\
\text { making }\end{array}$ & & & & & \\
\hline c. & $\begin{array}{l}\text { Consumes the resources of } \\
\text { administration, without proving } \\
\text { its practical utility. }\end{array}$ & & & & & \\
\hline
\end{tabular}

